\title{
The Western Sierras Pampeanas: Protracted Grenville-age history (1330-1030 Ma) of intra-oceanic arcs, subduction-accretion at continental-edge and AMCG intraplate magmatism
}

\author{
C.W. Rapela ${ }^{\mathrm{a}, *}$, R.J. Pankhurst ${ }^{\mathrm{b}}$, C. Casquet $^{\mathrm{c}}$, E. Baldo ${ }^{\mathrm{d}}$, C. Galindo ${ }^{\mathrm{c}}$, C.M. Fanning ${ }^{\mathrm{e}}$, J.M. Dahlquist ${ }^{\mathrm{d}}$ \\ ${ }^{a}$ Centro de Investigaciones Geológicas, Universidad Nacional de La Plata-CONICET, 1900 La Plata, Argentina \\ ${ }^{\mathrm{b}}$ British Geological Survey, Keyworth, Nottingham NG12 5GG, United Kingdom \\ ${ }^{\mathrm{c}}$ Departamento de Petrología y Geoquímica, Universidad Complutense, 28040 Madrid, Spain \\ ${ }^{\mathrm{d}}$ Departamento de Geología, Universidad Nacional de Córdoba, 5000 Córdoba, Argentina \\ ${ }^{\mathrm{e}}$ Research School of Earth Sciences, The Australian National University, Canberra, Australia
}

\section{A R T I C L E I N F O}

Article history:

Received 9 February 2009

Accepted 5 August 2009

\section{Keywords:}

Sierras Pampeanas

Grenville-age orogeny

Intra-oceanic arc

Arc-continent collision

AMCG complex

$\mathrm{U}-\mathrm{Pb}$ SHRIMP dating

\begin{abstract}
A B S T R A C T
New U-Pb SHRIMP zircon ages combined with geochemical and isotope investigation in the Sierra de Maz and Sierra de Pie de Palo and a xenolith of the Precordillera basement (Ullún), provides insight into the identification of major Grenville-age tectonomagmatic events and their timing in the Western Sierras Pampeanas. The study reveals two contrasting scenarios that evolved separately during the $300 \mathrm{Ma}$ long history: Sierra de Maz, which was always part of a continental crust, and the juvenile oceanic arc and back-arc sector of Sierra de Pie de Palo and Ullún. The oldest rocks are the Andino-type granitic orthogneisses of Sierra de Maz (1330-1260 Ma) and associated subalkaline basic rocks, that were part of an active continental margin developed in a Paleoproterozoic crust. Amphibolite facies metamorphism affected the orthogneisses at ca. $1175 \mathrm{Ma}$, while granulite facies was attained in neighbouring meta-sediments and basic granulites. Interruption of continental-edge magmatism and high-grade metamorphism is interpreted as related to an arc-continental collision dated by zircon overgrowths at 1170-1230 Ma. The next event consisted of massif-type anorthosites and related meta-jotunites, meta-mangerites $(1092 \pm 6 \mathrm{Ma})$ and meta-granites $(1086 \pm 10 \mathrm{Ma})$ that define an AMCG complex in Sierra de Maz. The emplacement of these mantle-derived magmas during an extensional episode produced a widespread thermal overprint at ca. $1095 \mathrm{Ma}$ in neighbouring country rocks. In constrast, juvenile oceanic arc and back-arc complexes dominated the Sierra de Pie de Palo-Ullún sector, that was fully developed ca. $1200 \mathrm{Ma}$ (1196 \pm 8 Ma metagabbro). A new episode of oceanic arc magmatism at $\sim 1165$ Ma was roughly coeval with the amphibolite high-grade metamorphism of Sierra de Maz, indicating that these two sectors underwent independent geodynamic scenarios at this age. Two more episodes of arc subduction are registered in the Pie de Palo-Ullún sector: (i) $1110 \pm 10$ Ma orthogneisses and basic amphibolites with geochemical fingerprints of emplacement in a more mature crust, and (ii) a $1027 \pm 17$ Ma TTG juvenile suite, which is the youngest Grenville-age magmatic event registered in the Western Sierras Pampeanas. The geodynamic history in both study areas reveals a complex orogenic evolution, dominated by convergent tectonics and accretion of juvenile oceanic arcs to the continent.
\end{abstract}

(c) 2009 Elsevier Ltd. All rights reserved.

\section{Introduction}

In the $26-33^{\circ} \mathrm{S}$ flat-slab segment of the Nazca plate in the Southern Andes, present-day landforms result from basement uplift on Miocene-to-Recent reverse faults located up to $900 \mathrm{~km}$ away from the trench. These basement exposures of the Sierras Pampeanas give a unique opportunity to test models of lateral accretion

\footnotetext{
* Corresponding author. Fax: +54 2214827560.

E-mail_addresses: crapela@cig.museo.unlp.edu.ar, crapela@way.com.ar (C.W. Rapela).
}

of the continent, from the 2.0-2.2 Ga Paleoproterozoic sequences of the Río de la Plata craton in the east, to the modern Andes in the west (Fig. 1). Based on lithological differences, Caminos (1979) was the first to recognize an eastern group of sierras dominated by abundant Paleozoic granites and metasedimentary rocks (the Eastern Sierras Pampeanas), and a western group characterized by abundant meta-basic, ultrabasic and calc-silicate rocks (the Western Sierras Pampeanas). Modern geochronological studies have demonstrated that the Western Sierras Pampeanas (WSP) preserve a completely different geological history, involving an exposed Mesoproterozoic crystalline basement (e.g., McDonough 


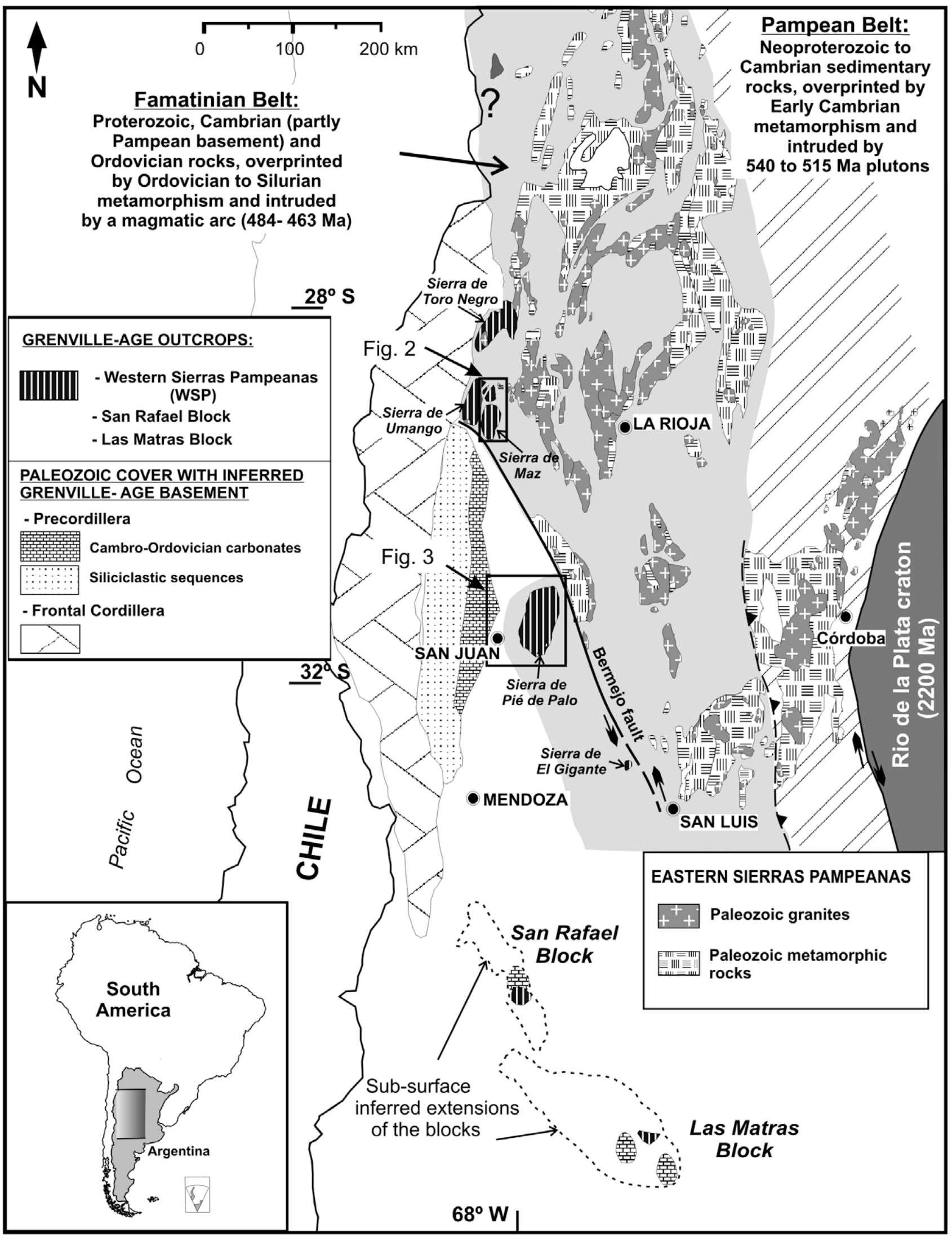

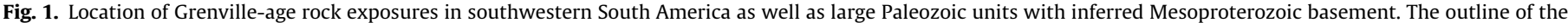
San Rafael and Las Matras blocks are after Sato et al. (2000).

et al., 1993; Pankhurst and Rapela, 1998; Varela et al., 2003; Casquet et al., 2001, 2004; Vujovich et al., 2004). From north to south, the main sierras of the WSP are Toro Negro, Umango, Espinal, Maz, Pie de Palo and El Gigante (Fig. 1). Mesoproterozoic ages have been 
also reported to the south of the WSP, in low-relief outcrops of the San Rafael block at $35^{\circ} \mathrm{S}$ (Astini et al., 1996; Cingolani and Varela, 1999) and scattered outcrops of tonalite-trondhjemites in the Las Matras block at $36^{\circ} 46^{\prime}$ S (Sato et al., 2000, 2004) (Fig. 1). To the west of the WSP, the basement of the Early Paleozoic sequences of the Precordillera is inferred to be Mesoproterozoic in age, based on studies of xenoliths in tertiary volcanic rocks (Abruzzi et al., 1993; Kay et al., 1996), while geochronological data obtained from scattered outcrops of the basement in the Late Paleozoic Frontal Cordillera show that the Grenville-age basement extends further west (Ramos and Basei, 1997; Basei et al., 1998) (Fig. 1). Therefore, a large sector of the Southern Andes basement and foreland, at least $1100 \mathrm{~km}$ long, is formed by Grenville-age blocks whose relationships to each other are largely unknown.

The aim of this paper is to start unravelling the early history of this collage of continental blocks by means of a comparative study of the chemistry, isotopic composition, and magmatic-metamorphic history of Sierra de Maz and Sierra de Pie de Palo, two of the largest and best exposed units of the WSP. As in any geological study of the WSP, ours is hampered by a number of uncertainties derived from the numerous rifting and orogenic events overprinted on the Grenville-age basement. Some of the detected overprinting events include: (a) rifting episodes recorded by intrusion of A-type granites at 840 and $770 \mathrm{Ma}$ (Baldo et al., 2006, 2008), and carbonatites and nepheline syenites at $570 \mathrm{Ma}$ (Casquet et al., 2008), (b) Early Paleozoic metamorphism associated with the docking/collision/strike-slip displacement of the WSP and the Precordillera terrane during their final attachment to Gondwana (this has been the topic of much debate in recent years, and reviews have been reported in a special symposium of the 33rd IGC (Casquet et al., 2008; Finney, 2008; Thomas and Astini, 2008), and (c) deformation related to the Late Paleozoic (Gondwanan) and Andean orogenies. The effect of the important Late Paleozoic deformation on the basement is poorly known, whereas the Tertiary-Recent block uplift on reverse faults and imbrication have been better studied. As a result of the Early Paleozoic and Andean tectonics, Grenville-age blocks are imbricated with post-Grenvillian terranes (Casquet et al., 2008), and very detailed studies are needed to establish connections between even adjacent lithological domains.

\section{Geological setting}

\subsection{Sierra de Maz}

In the basement of the sierras of Maz and Espinal three domains, separated by first-order shear zones and younger faults (Fig. 2), can be distinguished on the basis of field, geochronology and isotope composition evidence (Casquet et al., 2006; 2008 and references therein). The Eastern Domain consists for the most part of high-grade rocks younger than $1.0 \mathrm{Ga}$ (garnet-sillimanite migmatites and paragneisses with subordinate marbles and amphibolites). Metamorphism took place during the Famatinian orogeny at ca. $440 \mathrm{Ma}$ (see also Lucassen and Becchio, 2003). The Central Domain (also known as the Maz Domain) consists of medium-grade meta-sediments (kyanite-sillimanite-garnet-staurolite schists, quartzites, amphibolites and marbles) and high-grade ultramafic to intermediate meta-igneous and metasedimentary rocks that underwent a Grenville-age orogeny starting at ca. 1.2 Ga (Porcher et al., 2004; Casquet et al., 2006). Deposition of the sedimentary protolith sequences occurred during the Paleoproterozoic (between 1.7 and $1.9 \mathrm{Ga}$, U-Pb SHRIMP age of detrital zircon, Casquet et al., 2006). Massif-type meta-anorthosites and associated meta-jotunite dykes of $1070 \pm 41 \mathrm{Ma}$ are restricted to the eastern side of the Central Domain and show evidence for Famatinian metamorphic rejuvenation at $431 \pm 40 \mathrm{Ma}$ (observed throughout the domain, Casquet et al., 2004). Moreover, metamorphic and geochronological discontinuities within the Maz Domain suggest that it is in fact composed of a number of slivers separated by shear zones. All the samples analysed in this study are from the Maz Central Domain (Fig. 2). The Western Domain consists again of metasedimentary rocks younger than $1.0 \mathrm{Ga}$ that underwent Famatinian metamorphism. One sequence of rocks composed of thick marble beds, calcic pelitic schists and quartzites is probably equivalent to the Neoproterozoic Difunta Correa metasedimentary sequence of Sierra de Pie de Palo, and to isotopically-similar rocks of Sierra de Umango (Varela et al., 2001; Galindo et al., 2004). Most rocks within this domain are low- to medium-grade, but highgrade rocks are found locally.

Mylonitic A-type orthogneisses of 840 Ma have been recently reported in the Maz Central Domain and Sierra de Espinal (Baldo et al., 2008), while ca. 570 Ma carbonatites and associated Ne-syenites probably represent the latest rifting event of the Grenvilleage block before amalgamation to Gondwana (Casquet et al., 2008).

\subsection{Sierra de Pie de Palo}

Sierra de Pie de Palo exposes a meta-igneous and metasedimentary complex of stacked nappes thrust towards the west during the Early Paleozoic (Fig. 3). The nappes rest upon the almost unmetamorphosed Precordillera passive-margin sequence of early Cambrian age (Caucete Group), below the Pirquitas basal thrust (Galindo et al., 2004; Ramos et al., 1996; Mulcahy et al., 2007) (Fig. 3).

Grenvillian ages from Sierra de Pie de Palo first reported by Varela and Dalla Salda (1993), McDonough et al. (1993) and Pankhurst and Rapela (1998) were later confirmed in other studies (e.g., Casquet et al., 2001; Vujovich et al., 2004). Two domains with well-constrained Mesoproterozoic lithologies are recognized. A structurally lower unit of mostly meta-mafic and meta-ultramafic rocks composed of serpentinite and metapyroxenite bodies, massive metagabbros, metadiorites, mafic schists, amphibolites and garnet-amphibolites (Vujovich and Kay, 1998 and references therein). This unit is referred to in the geological map (Fig. 3) as the Grenvillian "oceanic arc back-arc complex" (see below). It overlies the siliciclastic and carbonate platform sequences of the Early Paleozoic Caucete Group along the Pirquitas thrust (Vujovich and Kay, 1998) (Fig. 3). An upper imbricate thrust sequence of marbles, calc-silicate rocks, schists, gneisses, quartzites, subordinate amphibolites and abundant acidic orthogneisses, including meta-trondhjemites and meta-tonalites, dominate the central and eastern part of the sierra (Fig. 3). Isotope studies and detrital zircon ages obtained from marbles, calc-silicate schists, quarztites and amphibole-garnet schists in the southern part of the sierra, previously considered Mesoproterozoic, indicate that these rocks in fact constitute a distinct Neoproterozoic platform sequence, the Difunta Correa sequence (580-620 Ma, Galindo et al., 2004; Rapela et al., 2005), which overlies Mesoproterozoic basement. A-type granitic orthogneisses dated at $870 \mathrm{Ma}$ (Baldo et al., 2006), the Difunta Correa metasedimentary sequence and the Mesoproterozoic basement are thoroughly imbricated in the central and eastern part of the sierra. Although a detailed knowledge of the Mesoproterozoic basement in the upper imbricate thrust sequence is still missing, but the assembled lithological includes different types of amphibolites, orthogneisses and metasedimentary rocks. Determination of stratigraphical relationships is however hampered by the strong deformation and difficult access. Intrusion of Early Ordovician granites (470-481 Ma, Pankhurst and Rapela, 1998; Baldo et al., 2005) and Middle Ordovician amphibolite facies metamorphism (455-460 Ma, Casquet et al., 2001; Vujovich et al., 2004) are among the later events registered in Pie de Palo. 


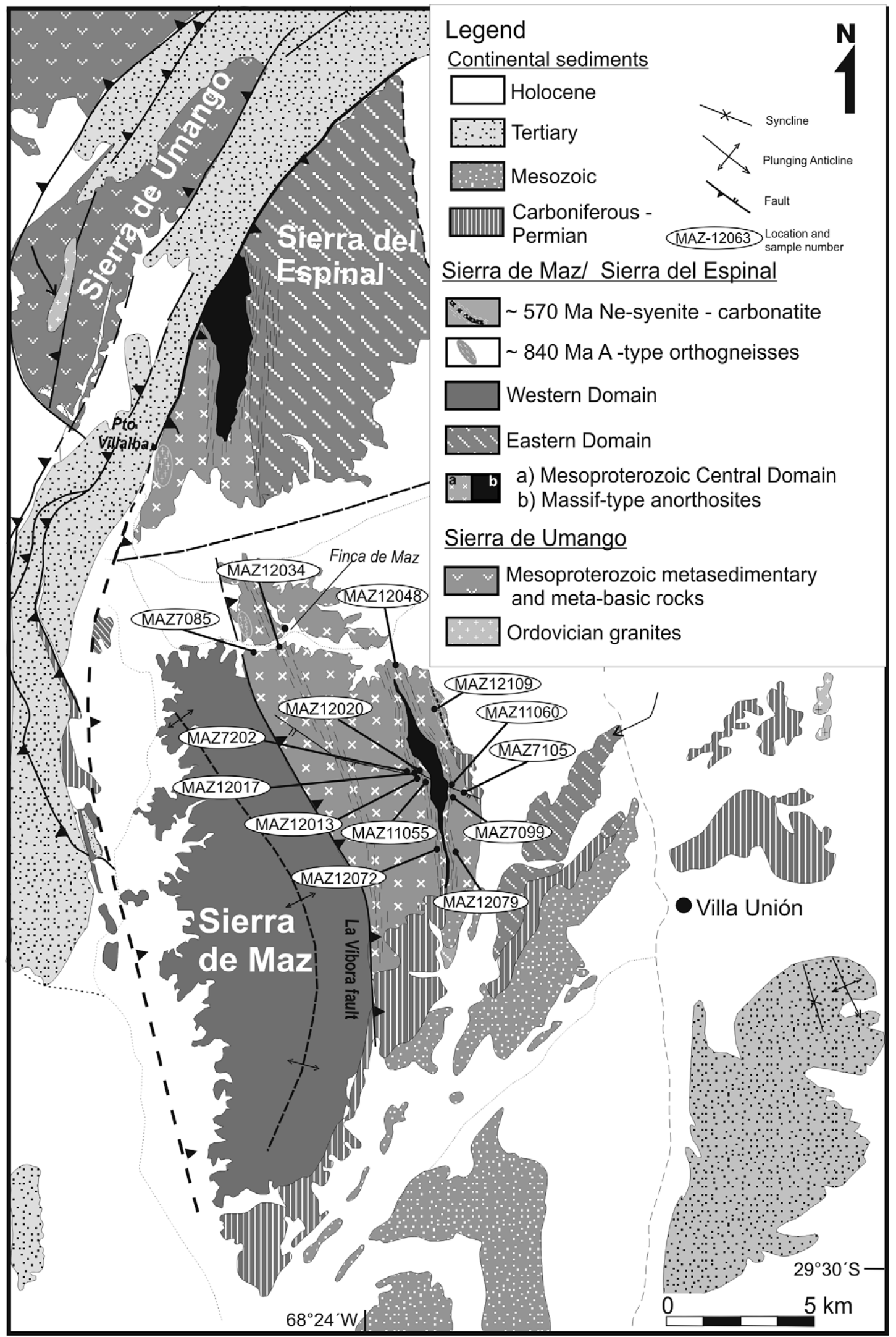

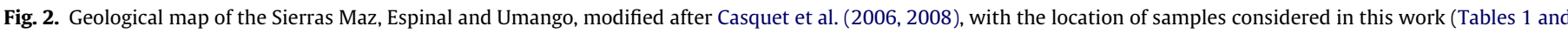
4).

Based on geochemical data, Vujovich and Kay (1998) interpreted the overall Grenville-age rocks of Pie de Palo as formed in an oceanic arc/back-arc complex similar to those in the western Pacific region. A U-Pb age of $1204 \pm 5 \mathrm{Ma}$ obtained in a gabbroic 


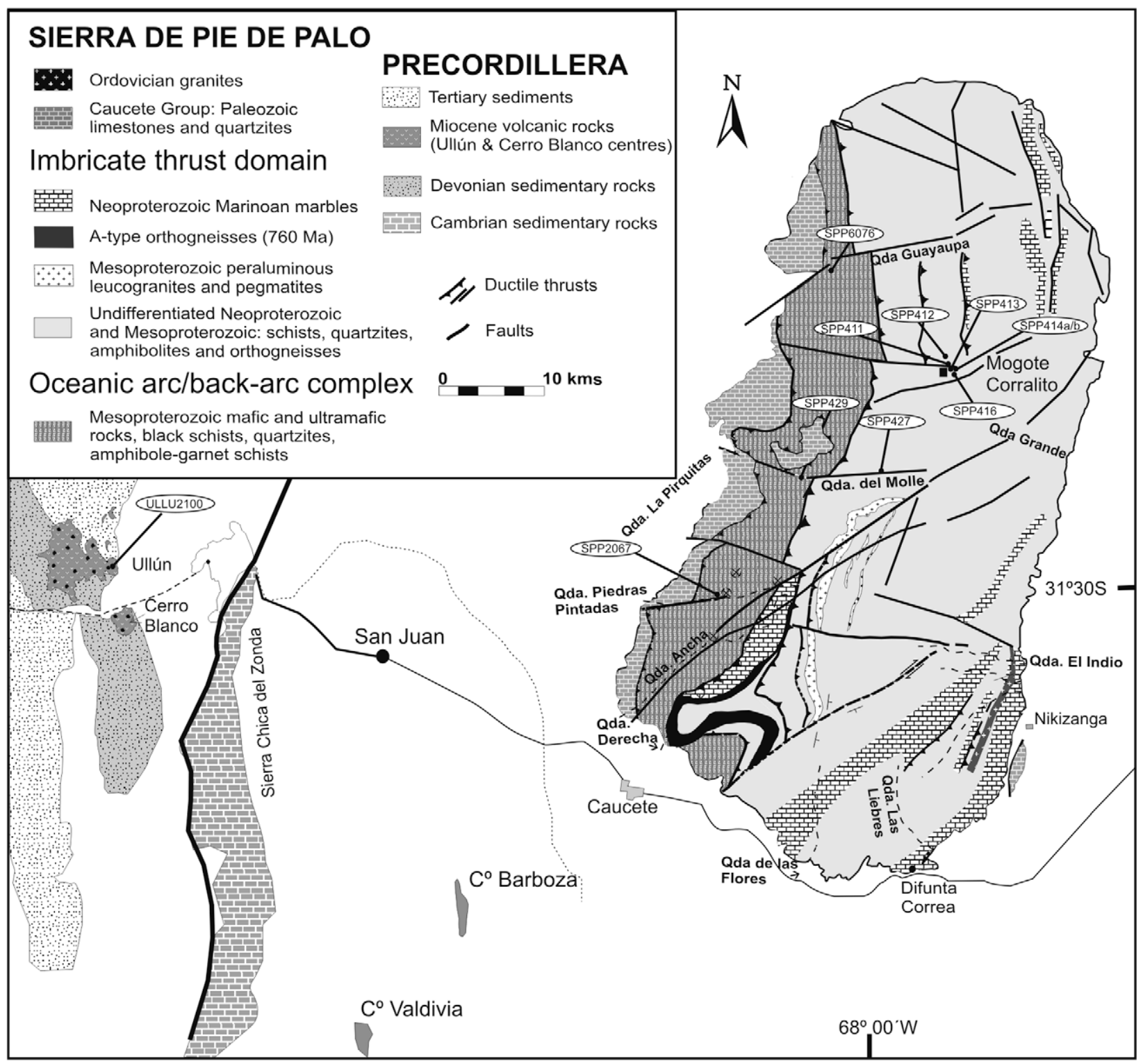

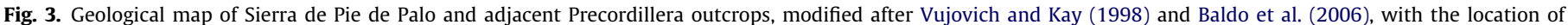
samples considered in this work (Tables 3 and 4).

pegmatite of the lower unit constrains the timing of the assumed arc rifting and back-arc spreading stage (Vujovich et al., 2004). $\mathrm{U}-\mathrm{Pb}$ ages of $1169 \pm 8$ and $1174 \pm 43 \mathrm{Ma}$ obtained from tonaliticgranodioritic sills and dykes that intrude both Mesoproterozoic domains were interpreted as representing either arc activity during and after back-arc spreading or a tectonically-unrelated arc (Vujovich et al., 2004).

\subsection{The basement of the Precordillera: the Ullún xenoliths}

The Cambrian and Early Ordovician sedimentary sequence of the Precordillera, located adjacent to the west of Sierra de Pie de Palo (Fig. 1), has no exposed underlying basement. Only indirect evidence of the age and composition of this basement comes from xenoliths included in Miocene dacitic to andesitic rocks that penetrated the Cambro-Ordovician strata. The best studied localities are the Ullún and Cerro Blanco volcanic centres described by Leveratto (1968) and Abruzzi et al. (1993), subsequently studied in more detail by Kay et al. (1996).
Metamorphic xenoliths, ranging in size from $<3 \mathrm{~cm}$ up to $25 \mathrm{~cm}$ across, were considered by Abruzzi et al. (1993) and Kay et al. (1996) to have been mostly derived from mafic $\left(\mathrm{SiO}_{2}=48-54 \%\right)$ and felsic $\left(\mathrm{SiO}_{2}=69-71 \%\right)$ igneous protoliths. Three distinct xenolith suites were recognized:

(i) mafic pyroxene granulite and pyroxene-garnet granulite gneiss interpreted as derived from basaltic to basalticandesitic magmas formed in an oceanic back-arc or juvenile continental crustal back-arc setting.

(ii) deformed mafic amphibolitic schists interpreted as representing unfractionated mantle-derived arc magmas. An U-Pb zircon age for one sample from this suite yielded an upper intercept age of $1102 \pm 6 \mathrm{Ma}$, which was considered a crystallization age. Two zircon fractions from the same sample, but with lower $\mathrm{U}$ and $\mathrm{Pb}$ concentrations, defined a $\sim 1083 \mathrm{Ma}$ ${ }^{207} \mathrm{~Pb} /{ }^{206} \mathrm{~Pb}$ age, interpreted as a metamorphic event.

(iii) biotite-bearing acid gneisses of dacitic composition interpreted as crustal melts. Zircon data from two samples of this 
group are highly discordant: three fractions from one sample yield an upper intercept age of $1096 \pm 50 \mathrm{Ma}$, while if the all six fractions from the samples are regressed together, the resulting upper intercept age is $1118 \pm 54 \mathrm{Ma}$.

\section{Geochemistry and Nd isotope data: tectonomagmatic affinities}

\subsection{Sierra de Maz}

The database for Sierra de Maz consists of 26 new whole-rock chemical analyses and $12 \mathrm{Nd}$ isotope determinations on selected samples of the main meta-igneous units of the Central Domain (see Tables 1 and 2 (data repository), and Fig. 2 for sample location). Amphibolites and orthogneisses of the Central Domain exhibit a silica range from $45 \%$ to $74 \% \mathrm{SiO}_{2}$ and can be subdivided in two main groups (Fig. 4). A first group of subalkaline samples (calcic to calc-alkaline fields, Fig. $4 \mathrm{a}$ and b), is composed of medium-K amphibolites $\left(46-48 \% \mathrm{SiO}_{2}\right)$, separated by a silica gap of $62-74 \%$ $\mathrm{SiO}_{2}$ from mostly medium-K orthogneisses (Fig. 4c). This subalkaline group, as well as metasedimentary schists and gneisses, are the country rock of the anorthosite massif in the northeastern side of Sierra de Maz (Fig. 2).

A second group includes meta-anorthosites, meta-jotunites and an alkali-calcic series defined by high-K orthogneisses that plot in the monzonite and quartz monzonite fields of the plutonic TAS diagram (Fig. 4a and b). High-K amphibolites with shoshonite composition are tentatively linked to this group (Fig. 4c). Note that the massif-type meta-anorthosites of Sierra de Maz plot in the monzodiorite and monzogabbro fields (Fig. 4a). The trace element geochemistry and $\mathrm{Nd}$ isotope signature of both groups are described in more detail below (Figs. 5, 6 and 10).

\subsubsection{Subalkaline series: Andean type, cordilleran granites and subduction-related basic rocks}

The first group of subalkaline orthogneisses consists of metamorphosed diorites, tonalites, granodiorites and monzoganites, with $\mathrm{SiO}_{2}$ 62-74\%, $\mathrm{Na}_{2} \mathrm{O}+\mathrm{K}_{2} \mathrm{O}$ 5.2-6.7\%, FeOt $+\mathrm{MgO} 3-7 \%$, REE patterns with $[\mathrm{La} / \mathrm{Yb}]_{\mathrm{N}}=10-45$ and a weak positive Eu anomaly $\left(\mathrm{Eu} / \mathrm{Eu}^{*}=1.1-1.4\right)$ (Table 1, Fig. 5a). The overall subalkaline geochemistry of these meta-granitic rocks is coupled with $\mathrm{Ga} / \mathrm{Al}$ $\left(1000^{*} \mathrm{Ga} / \mathrm{Al}=2.0-2.5\right), \mathrm{FeOt} / \mathrm{MgO}(2-8), \mathrm{Zr} / \mathrm{Nb}(>17)$ and $\mathrm{Ba} / \mathrm{La}$ (15-50) ratios that are characteristic of metaluminous magmas emplaced in convergent margins rather than intraplate settings (Pearce et al., 1984; Whalen et al., 1987; Eby 1990). Normalized to Ocean Ridge Granites (ORG) the subalkaline orthogneisses are enriched in $\mathrm{K}, \mathrm{Rb}$ and $\mathrm{Ba}$ and depleted in $\mathrm{Ta}, \mathrm{Nb}, \mathrm{Hf}, \mathrm{Zr}, \mathrm{Y}$, and $\mathrm{Yb}$, which is also typical of arc-related magmas (Fig. 5b), in particular the cordilleran tonalitic to granitic suites (e.g., Hervé et al., 2007). The $\varepsilon N d t$ values range from +4.1 for the tonalite/diorite to -0.8 in the granodiorite and -7.2 in the granite (Fig. 6 , Table 1 ). This indicates a significant amount of mature continental crust contamination of the acidic units, whereas the tonalite/diorite preserves the typical mantle signature of cordilleran tonalites.

The medium-K subalkaline amphibolites show some arc geochemical affinities, such as LILE- and Th enrichment and compatible element depletion when normalized against N-MORB, but they do not show other characteristics such as LREE enrichment and Nb depletion (Fig. 5c). $\varepsilon$ Ndt varies from +3 to -1.5 , with the typical range of $\mathrm{Zr}$ content for subalkaline rocks (30-60 ppm, Fig. 6). As in the case of the subalkaline orthogneisses, this variation in $\varepsilon \mathrm{Ndt}$ correlates with an increase of silica content, from $45.8 \%$ to $48.5 \%$ (Fig. 4, Table 1), again suggesting crustal contamination of the original basic magmas. These subalkaline meta-basic rocks, and the meta-granitic suite, have the typical igneous lithology formed in convergent margins such as the southern Andes, where basalt and basaltic-andesite stratovolcanoes and cordilleran batholiths largely constitute the edge of the continent (Hervé et al., 2007).

\subsubsection{Alkali-calcic orthogneisses and massif-type anorthosites: an AMCG complex}

The high-K alkali-calcic orthogneisses and amphibolites of the Central Domain show all the geochemical characteristic of a magmatic series that is transitional to the alkaline field. The orthogneisses are meta-monzonite and meta-quartz monzonites with $\mathrm{SiO}_{2}$ 57.1-68.4\%, $\mathrm{Na}_{2} \mathrm{O}+\mathrm{K}_{2} \mathrm{O}$ 6.8-8.6\%, $\mathrm{FeOt}+\mathrm{MgO}$ 3.8-9.2\%, REE patterns with $[\mathrm{La} / \mathrm{Yb}]_{\mathrm{N}}=3-15$ and a positive Eu anomaly $(\mathrm{Eu} /$ $\mathrm{Eu}^{*}=1.1-1.7$ ) (Table 1, Fig. 5a). This mild alkaline signature is also observed in the relatively high contents of incompatible elements, both LILE and HFSE (Fig. 5b), and the high ratios of $\mathrm{Ga} / \mathrm{Al}\left(1000^{*} \mathrm{Ga} /\right.$ $\mathrm{Al}=2.5-3.5)$ and $\mathrm{FeOt} / \mathrm{MgO}(7-25)$ are diagnostic of A-type granites and, generally, of acidic within-plate magmatism (Pearce et al., 1984; Leat et al., 1986; Whalen et al., 1987; Eby, 1990). The $\mathrm{Zr}$ content has been considered useful for the recognition of alkaline signatures in rhyolitic rocks, and low- $\mathrm{Zr}(<300 \mathrm{ppm})$ rocks are termed "subalkaline", while high- $\mathrm{Zr}(>350 \mathrm{ppm})$ are classed as "peralkaline" (Leat et al., 1986). The $\mathrm{Zr}$ content of the high-K orthogneisses is very high (450-1150 ppm), and they also have $\varepsilon N d t$ values of +0.3 and -4.5 (Fig. 6 ), the latter indicating participation of the crust in the granitic source. Hypersthene-bearing monzonite and granitic rocks with intraplate signatures are often associated with massif-type anorthosites, producing the so-called AMCG complex (Anorthosites-Mangerites-Charnockites-Granites) (Emslie, 1978), which are common in the Grenville province of Canada (Corrigan and Hanmer, 1997; Rivers, 1997) and in the Appalachian Grenvillian basement. The original anorthosites, monzonites and quartz monzonites of Sierra de Maz underwent a Lower Paleozoic medium to high-grade event that transformed the original fabric and mineralogy during the docking of the Western Sierras Pampeanas against Gondwana (Casquet et al., 2008a). It is considered here that the high-K alkali-calcic orthogneisses and adjacent anorthositic massif of Sierra de Maz (Fig. 2) formed an intraplate AMCG complex, emplaced during a single broad magmatic episode (see geochronological section).

\subsubsection{The Maz massif anorthosite}

The anorthositic massif of Sierra de Maz (Fig. 2) was first described by Casquet et al. (2004). Although this body has been also affected by Lower Paleozoic medium to high-grade metamorphism and deformation, it is one of the best preserved Grenville-age magmatic units of the Western Sierras Pampeanas. Original relationships between the different anorthositic facies and the related mafic jotunites are still recognized, so that mathematical modelling of igneous geochemical trends can be used to constrain the fractional crystallization history. A refinement of the data and model presented by Casquet et al. (2004) is based on 12 new chemical analyses reported in Table 2 (data repository).

The main facies of the anorthosites is dominated by intermediate plagioclase showing sparse small pockets of mafic minerals. Occasionally, the proportion of mafic minerals increases, forming a jotunite groundmass with plagioclase phenocrysts or synplutonic dykes within the main facies. The bulk leucocratic anorthosites have high $\mathrm{Al}_{2} \mathrm{O}_{3}(23.5-27.5 \%)$ and $\mathrm{Sr}(720-930 \mathrm{ppm})$, and low to moderate $\mathrm{K}_{2} \mathrm{O}(0.4-1.5 \%)$. They display moderately LREE-enriched chondrite-normalized patterns $\left(\mathrm{La} / \mathrm{Yb}_{\mathrm{N}}=32-5\right)$ and positive $\mathrm{Eu}$ anomalies $\left(\mathrm{Eu} / \mathrm{Eu}^{*}=13.5-2.5\right)$ (Fig. 7a). The $\mathrm{SiO}_{2}$-poor jotunites $\left(\mathrm{SiO}_{2} 38.9-48.1 \%\right)$ are enriched in $\mathrm{FeO}, \mathrm{TiO}_{2}, \mathrm{MgO}, \mathrm{P}_{2} \mathrm{O}_{5}, \mathrm{Zr}, \mathrm{Hf}$, and $\mathrm{Ta}$, and depleted in $\mathrm{Al}_{2} \mathrm{O}_{3}, \mathrm{Na}_{2} \mathrm{O}$, and $\mathrm{Sr}$; their REE patterns are enriched in total REE with a slight negative to positive Eu anomaly $\left(\mathrm{Eu} / \mathrm{Eu}^{*}=0.85-1.1\right)$ (Figs. 4 and $\left.7 \mathrm{a}\right)$. The Nd isotope compositions of the anorthosites and jotunites are variable: $\varepsilon N d t=+3.4$ 
Table 1

Geochemical and isotope data of orthogneisses and amphibolites from Sierra de Maz.

\begin{tabular}{|c|c|c|c|c|c|c|c|c|c|c|c|c|c|c|}
\hline \multirow[b]{3}{*}{$\begin{array}{l}\text { Sample } \\
\text { (wt\%)* }\end{array}$} & \multicolumn{8}{|c|}{ Subalkaline Series } & \multicolumn{6}{|c|}{ Alkali-calcic Series } \\
\hline & \multicolumn{3}{|c|}{ Amphibolites } & \multicolumn{5}{|c|}{ Orthogneisses } & \multicolumn{3}{|c|}{ Amphibolites } & \multicolumn{3}{|c|}{ Orthogneisses } \\
\hline & 12,079 & 7202 & 7105 & 7099 & 11,060 & 12,109 & 12,013 & 12,048 & 12,034 & 7085 & 12,017 & 12,020 & 11,055 & 12,072 \\
\hline $\mathrm{SiO}_{2}$ & 45.87 & 48.38 & 48.54 & 62.14 & 62.26 & 66.27 & 72.04 & 73.66 & 45.06 & 47.18 & 54.11 & 57.11 & 57.67 & 68.45 \\
\hline $\mathrm{TiO}_{2}$ & 1.15 & 0.44 & 1.15 & 0.64 & 0.59 & 0.74 & 0.50 & 0.26 & 1.80 & 1.86 & 2.38 & 1.29 & 1.03 & 0.47 \\
\hline $\mathrm{Al}_{2} \mathrm{O}_{3}$ & 17.13 & 16.54 & 12.86 & 17.80 & 17.67 & 14.60 & 13.56 & 14.11 & 14.03 & 15.33 & 12.72 & 15.93 & 16.56 & 15.17 \\
\hline $\mathrm{Fe}_{2} \mathrm{O}_{3} \mathrm{t}$ & 13.36 & 11.53 & 16.22 & 4.64 & 4.25 & 5.68 & 3.87 & 2.58 & 14.90 & 12.93 & 16.01 & 10.43 & 8.54 & 3.62 \\
\hline $\mathrm{MnO}$ & 0.17 & 0.18 & 0.21 & 0.07 & 0.06 & 0.09 & 0.06 & 0.04 & 0.21 & 0.20 & 0.27 & 0.18 & 0.17 & 0.05 \\
\hline $\mathrm{MgO}$ & 6.57 & 8.19 & 6.26 & 2.27 & 1.99 & 2.02 & 0.43 & 0.65 & 10.79 & 7.14 & 1.70 & 1.01 & 0.81 & 0.44 \\
\hline $\mathrm{CaO}$ & 11.22 & 9.93 & 10.82 & 5.57 & 5.49 & 4.09 & 2.46 & 2.61 & 8.49 & 8.17 & 6.05 & 5.42 & 4.96 & 2.12 \\
\hline $\mathrm{Na}_{2} \mathrm{O}$ & 1.71 & 1.98 & 1.99 & 4.89 & 4.78 & 3.31 & 2.66 & 3.05 & 1.14 & 2.84 & 2.04 & 3.99 & 3.76 & 2.86 \\
\hline $\mathrm{K}_{2} \mathrm{O}$ & 0.95 & 0.96 & 0.89 & 1.24 & 1.35 & 2.04 & 4.12 & 2.16 & 1.29 & 2.66 & 2.28 & 2.88 & 3.77 & 5.73 \\
\hline $\mathrm{P}_{2} \mathrm{O}_{5}$ & 0.12 & 0.10 & 0.13 & 0.18 & 0.16 & 0.24 & 0.15 & 0.06 & 0.34 & 0.38 & 1.24 & 0.52 & 0.32 & 0.19 \\
\hline LOI & 1.20 & 1.35 & 0.44 & 0.58 & 2.70 & 0.75 & 0.49 & 0.87 & 1.69 & 1.35 & 0.34 & 0.92 & 2.42 & 1.01 \\
\hline $\begin{array}{l}\text { Total } \\
\qquad(\mathrm{ppm})^{*}\end{array}$ & 99.45 & 99.58 & 99.51 & 100.02 & 101.3 & 99.83 & 100.34 & 100.05 & 99.74 & 100.04 & 99.14 & 99.68 & 100.01 & 100.11 \\
\hline Cs & 0.1 & 0.2 & n.d & 0.4 & 0.3 & 0.3 & 0.1 & 0.4 & 1.6 & 0.7 & 0.5 & 0.2 & 0 & 0.4 \\
\hline $\mathrm{Rb}$ & 12 & 27 & 4 & 20 & 33 & 59 & 60 & 34 & 33 & 59 & 57 & 31 & 33 & 132 \\
\hline $\mathrm{Sr}$ & 428 & 264 & 117 & 824 & 888 & 586 & 284 & 494 & 57 & 247 & 304 & 468 & 584 & 403 \\
\hline $\mathrm{Ba}$ & 265 & 173 & 108 & 640 & 596 & 1273 & 1416 & 1636 & 114 & 431 & 797 & 2735 & 5592 & 2995 \\
\hline La & 11.6 & 4.8 & 3.9 & 11.5 & 11.6 & 43.2 & 90.4 & 43 & 5.59 & 11.2 & 81.2 & 54.1 & 38.3 & 35.8 \\
\hline $\mathrm{Ce}$ & 21.8 & 11.7 & 9.1 & 27.6 & 24.7 & 85 & 182 & 80.4 & 16.4 & 31 & 193 & 131 & 83.6 & 70.7 \\
\hline $\mathrm{Pr}$ & 3.25 & 1.68 & 1.45 & 2.93 & 3.05 & 9.12 & 19.90 & 7.86 & 2.41 & 3.63 & 24.60 & 17.10 & 10.70 & 8.29 \\
\hline $\mathrm{Nd}$ & 13.2 & 8.4 & 7.7 & 13.1 & 12.7 & 33.1 & 72.6 & 25.4 & 12.7 & 17.6 & 105 & 73.8 & 47.9 & 32.7 \\
\hline $\mathrm{Sm}$ & 3.07 & 2.57 & 2.61 & 2.59 & 2.51 & 5.41 & 10.9 & 3.57 & 3.7 & 4.8 & 21 & 15 & 9.97 & 6.19 \\
\hline $\mathrm{Eu}$ & 1.00 & 1.04 & 0.94 & 0.91 & 0.99 & 1.93 & 3.29 & 1.3 & 1.71 & 1.79 & 4.94 & 5.9 & 7.44 & 3.3 \\
\hline $\mathrm{Gd}$ & 2.75 & 3.08 & 3.55 & 2.09 & 2.14 & 4.01 & 7.86 & 2.21 & 4.24 & 5.29 & 18.5 & 13.5 & 10.3 & 5.32 \\
\hline $\mathrm{Tb}$ & 0.49 & 0.58 & 0.75 & 0.3 & 0.31 & 0.59 & 1.13 & 0.26 & 0.79 & 0 & 3.08 & 2.21 & 1.54 & 0.74 \\
\hline Dy & 2.95 & 3.39 & 4.84 & 1.53 & 1.59 & 3.1 & 5.74 & 1.28 & 4.94 & 5.17 & 17.50 & 12.30 & 8.16 & 3.84 \\
\hline Ho & 0.57 & 0.71 & 1.06 & 0.28 & 0.29 & 0.59 & 1.00 & 0.24 & 0.94 & 1.03 & 3.22 & 2.26 & 1.6 & 0.73 \\
\hline $\mathrm{Er}$ & 1.60 & 1.97 & 3.21 & 0.81 & 0.85 & 1.66 & 2.72 & 0.71 & 2.64 & 2.86 & 9.19 & 6.3 & 4.55 & 1.92 \\
\hline $\mathrm{Tm}$ & 0.23 & 0.30 & 0.51 & 0.11 & 0.12 & 0.22 & 0.37 & 0.1 & 0.38 & 0.4 & 1.34 & 0.87 & 0.65 & 0.26 \\
\hline $\mathrm{Yb}$ & 1.42 & 1.82 & 3.21 & 0.77 & 0.78 & 1.38 & 2.48 & 0.65 & 2.39 & 2.63 & 8.33 & 5.42 & 4.17 & 1.56 \\
\hline Lu & 0.22 & 0.28 & 0.52 & 0.11 & 0.11 & 0.21 & 0.39 & 0.1 & 0.35 & 0.40 & 1.27 & 0.84 & 0.62 & 0.22 \\
\hline $\mathrm{U}$ & 0.34 & 0.15 & 0.04 & 0.09 & 0.04 & 0.19 & 0.49 & 0.44 & 0.27 & 0.6 & 0.5 & 0.59 & 0.5 & 0.4 \\
\hline Th & 1.15 & 0.53 & n.d & 0.2 & 0.05 & 5.59 & 4.59 & 7.48 & 0.43 & 1.03 & 1.94 & 1.28 & 1.12 & 0.97 \\
\hline $\mathrm{Y}$ & 15.8 & 19.6 & 31.8 & 8.0 & 9.0 & 15.2 & 25.2 & 5.8 & 26.1 & 28.2 & 91.5 & 64.1 & 41.5 & 19.0 \\
\hline $\mathrm{Nb}$ & 2.6 & 4.6 & 6.2 & 6.0 & 3.0 & 5.4 & 15.0 & 2.9 & 5.7 & 7.6 & 64.9 & 106 & 48.2 & 7.7 \\
\hline $\mathrm{Zr}$ & 43 & 56 & 62 & 124 & 89 & 273 & 435 & 149 & 96 & 140 & 863 & 1101 & 1150 & 450 \\
\hline $\mathrm{Hf}$ & 1.5 & 1.6 & 1.9 & 3.1 & 2.3 & 6.8 & 11.2 & 4.2 & 2.7 & 3.2 & 18.1 & 25.9 & 24.8 & 10.4 \\
\hline $\mathrm{Ta}$ & 0.14 & 0.68 & 0.08 & 0.12 & 0.13 & 0.21 & 0.45 & 0.09 & 3.71 & 0.34 & 3.85 & 6.9 & 4.5 & 0.47 \\
\hline Sc & 38 & 54 & 52 & 8 & 8 & 12 & 10 & 4 & 26 & 28 & 28 & 24 & 19 & 5 \\
\hline $\mathrm{Ga}$ & 21 & 17 & 16 & 19 & 21 & 17 & 18 & 15 & 18 & 16 & 24 & 27 & 22 & 23 \\
\hline $\mathrm{Ni}$ & 40 & 137 & 80 & $\mathrm{n}$ & $\mathrm{n}$ & 30 & 20 & 20 & 240 & 74 & 20 & 130 & $\mathrm{n}$ & 20 \\
\hline Co & 40 & 56 & 56 & 13 & 33 & 13 & 4 & 3 & 65 & 44 & 18 & 11 & 16 & 5 \\
\hline $\mathrm{Cr}$ & 50 & 318 & 81 & 32 & $\mathrm{n}$ & 60 & 20 & 90 & 690 & 214 & 20 & 20 & $\mathrm{n}$ & 80 \\
\hline $\mathrm{Pb}$ & 5 & $\mathrm{n}$ & n.d & 8 & 249 & 12 & 15 & 30 & 5 & 7 & 9 & 12 & 7 & 23 \\
\hline \multicolumn{15}{|c|}{$\mathrm{Nd}$ isotope data** } \\
\hline $\mathrm{Sm}(\mathrm{ppm})$ & & 2.57 & 2.61 & 2.59 & & & 10.9 & 3.57 & 3.7 & 4.8 & & 15.0 & & 6.19 \\
\hline Nd (ppm) & & 8.41 & 7.67 & 13.1 & & & 72.60 & 25.4 & 12.7 & 17.6 & & 73.8 & & 32.7 \\
\hline${ }^{147} \mathrm{Sm} /{ }^{144} \mathrm{I}$ & & 0.1847 & 0.2057 & 0.1195 & & & 0.0907 & 0.0849 & 0.1761 & 0.1649 & & 0.1229 & & 0.1144 \\
\hline${ }^{143} \mathrm{Nd} /{ }^{144} \mathrm{~N}$ & & 0.512532 & 0.512634 & 0.512212 & & & 0.511726 & 0.511351 & 0.512601 & 0.512513 & & 0.512123 & & 0.511819 \\
\hline$\varepsilon \mathrm{Ndt}$ & & -0.1 & -1.5 & 4.1 & & & -0.8 & -7.2 & 2.2 & 2.0 & & 0.3 & & -4.5 \\
\hline
\end{tabular}

All Sample Nos. have the prefix MAZ

Minor elements determined by ICP-MS spectrometry.

*Analyses carried out by ACTMajor elements determined by ICP spectrometry.

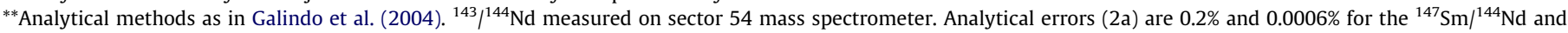
${ }^{143} /{ }^{144} \mathrm{Nd}$, respectively.

to -1.2 indicating a probable mantle source with moderate contamination by old continental crust (Casquet et al., 2004). A refined model of trace element fractional crystallization in which a sample of the main facies (MAZ12052, Table 2) and the jotunites are late stage residual liquids, is presented in Fig. $7 \mathrm{~b}$. The modelled daughter melts after $80 \%, 90 \%$, and $95 \%$ crystallization predict an increase in REEt and $\mathrm{Zr}$, a decrease in the initial positive Eu anomaly, which becomes slightly negative at $95 \%$ crystallization, and a decrease in the positive $\mathrm{Sr}$ anomaly, which becomes negative for the residual melts at $90-95 \%$ crystallization (Fig. 7b). Patterns displayed by the $\mathrm{SiO}_{2}$-poor jotunites $\left(\mathrm{SiO}_{2} 39-42 \%\right.$, Fig. 7a) are very similar to the modelled residual melts, in the production of which $\mathrm{Zr}$ behaves as an incompatible element.

\subsubsection{Alkali-calcic amphibolites}

Alkali-calcic amphibolites with $\mathrm{SiO}_{2}$ 45.1-54.1\%, $\mathrm{K}_{2} \mathrm{O}$ 1.3-2.7 and $\mathrm{Na}_{2} \mathrm{O}-2.0 \leqslant \mathrm{~K}_{2} \mathrm{O}$ (Table 1 and Fig. 1c) show affinities with the shoshonitic series (Ewart, 1982; Le Maitre, 1989). Samples with $\mathrm{SiO}_{2} 45-47 \%$ have REE patterns with $[\mathrm{La} / \mathrm{Yb}]_{\mathrm{N}}=2-2.5$ and weak positive $\mathrm{Eu}$ anomalies $\left(\mathrm{Eu} / \mathrm{Eu}^{*}=1.1-1.3\right)$, while a sample with $54 \%$ $\mathrm{SiO}_{2}$ shows an enriched pattern with $[\mathrm{La} / \mathrm{Yb}]_{\mathrm{N}}=7$ and a negative Eu anomaly $\left(\mathrm{Eu} / \mathrm{Eu}^{*}=0.75\right)$ (Table 1, Fig. 5a). Normalized against 
Table 2

Geochemical and isotope data of the anorthositic massif of Sierra de Maz.

\begin{tabular}{|c|c|c|c|c|c|c|c|c|c|c|c|c|}
\hline \multirow[t]{2}{*}{ Sample (wt\%)* } & \multicolumn{8}{|c|}{ Anorthosites } & \multicolumn{4}{|c|}{ Jotunites } \\
\hline & 12,050 & 12,027 & 12,053 & 12,073 & 12,024 & 12,023 & 12,052 & 12,068 & 12,025 & 12,049 & 12,028 & 12,026 \\
\hline $\mathrm{SiO}_{2}$ & 51.17 & 52.54 & 53.12 & 53.52 & 53.82 & 54.11 & 54.61 & 55.05 & 38.91 & 39.10 & 39.30 & 48.11 \\
\hline $\mathrm{TiO}_{2}$ & 1.53 & 0.88 & 0.12 & 0.61 & 0.10 & 0.28 & 0.10 & 0.28 & 3.61 & 3.69 & 3.59 & 2.02 \\
\hline $\mathrm{Al}_{2} \mathrm{O}_{3}$ & 23.72 & 23.81 & 26.77 & 25.46 & 26.36 & 26.15 & 27.56 & 25.39 & 13.81 & 11.82 & 11.70 & 17.40 \\
\hline $\mathrm{Fe}_{2} \mathrm{O}_{3} \mathrm{t}$ & 6.93 & 5.85 & 1.03 & 2.83 & 1.07 & 2.09 & 0.77 & 1.46 & 22.80 & 25.30 & 25.04 & 17.12 \\
\hline $\mathrm{MnO}$ & 0.13 & 0.09 & 0.02 & 0.04 & 0.01 & 0.03 & 0.01 & 0.02 & 0.28 & 0.41 & 0.41 & 0.30 \\
\hline $\mathrm{MgO}$ & 1.08 & 1.4 & 0.21 & 0.52 & 0.1 & 0.29 & 0.06 & 0.22 & 4.07 & 3.89 & 3.91 & 2.58 \\
\hline $\mathrm{CaO}$ & 9.27 & 8.97 & 9.71 & 9.36 & 9.09 & 9.57 & 10.34 & 8.68 & 11.07 & 9.90 & 9.37 & 8.44 \\
\hline $\mathrm{Na}_{2} \mathrm{O}$ & 4.3 & 4.41 & 4.82 & 4.67 & 5.3 & 5.27 & 5.06 & 5.25 & 1.13 & 2.81 & 2.40 & 2.58 \\
\hline $\mathrm{K}_{2} \mathrm{O}$ & 0.65 & 0.54 & 1.13 & 0.85 & 0.88 & 0.89 & 0.63 & 1.04 & 0.59 & 0.56 & 0.54 & 0.46 \\
\hline P2O5 & 0.27 & 0.12 & 0.04 & 0.08 & 0.08 & 0.09 & 0.04 & 0.07 & 2.33 & 2.60 & 2.11 & 1.13 \\
\hline LOI & 0.77 & 0.87 & 2.09 & 1.65 & 1.75 & 1.59 & 0.91 & 1.58 & 0.09 & 0.26 & 0.57 & 0.11 \\
\hline Total (ppm)* & 99.82 & 99.48 & 99.06 & 99.59 & 98.56 & 100.36 & 100.09 & 99.04 & 98.69 & 100.34 & 98.94 & 100.25 \\
\hline Cs & 0.3 & 0.2 & 0.5 & 1.2 & 2.6 & 1.5 & 0.2 & 2.3 & 0.1 & 0.1 & 0.1 & 0.1 \\
\hline $\mathrm{Rb}$ & 7 & 5 & 18 & 13 & 15 & 18 & 5 & 17 & 2326 & & & \\
\hline $\mathrm{Sr}$ & 727 & 745 & 927 & 763 & 838 & 812 & 857 & 801 & 123 & 582 & 553 & 437 \\
\hline $\mathrm{Ba}$ & 287 & 247 & 543 & 299 & 323 & 270 & 264 & 436 & 55 & 509 & 424 & 150 \\
\hline $\mathrm{La}$ & 9.93 & 6.29 & 4.32 & 6.27 & 5.24 & 6.52 & 4.25 & 6.51 & 81.7 & 62.9 & 54.2 & 27.5 \\
\hline $\mathrm{Ce}$ & 22.6 & 12.8 & 9 & 12.4 & 9.9 & 12.9 & 8.0 & 12.5 & 222.0 & 167.0 & 144.0 & 68.6 \\
\hline $\operatorname{Pr}$ & 2.93 & 1.47 & 1.06 & 1.40 & 1.06 & 1.44 & 0.86 & 1.39 & 32.60 & 24.20 & 20.80 & 9.18 \\
\hline $\mathrm{Nd}$ & 12.60 & 6.03 & 4.04 & 5.34 & 4.03 & 5.71 & 3.11 & 5.15 & 154.0 & 111.0 & 99.2 & 41.1 \\
\hline $\mathrm{Sm}$ & 2.49 & 1.19 & 0.82 & 1.02 & 0.70 & 1.06 & 0.48 & 0.88 & 35.20 & 25.20 & 22.30 & 8.96 \\
\hline $\mathrm{Eu}$ & 2.37 & 1.84 & 1.06 & 2.25 & 1.68 & 1.74 & 1.95 & 1.91 & 9.84 & 8.02 & 7.70 & 2.46 \\
\hline $\mathrm{Gd}$ & 2.42 & 1.16 & 0.71 & 0.93 & 0.51 & 0.90 & 0.40 & 0.76 & 31.90 & 25.00 & 20.80 & 8.46 \\
\hline $\mathrm{Tb}$ & 0.38 & 0.20 & 0.11 & 0.15 & 0.08 & 0.15 & 0.06 & 0.12 & 5.53 & 3.87 & 3.31 & 1.49 \\
\hline Dy & 2.19 & 1.22 & 0.66 & 0.86 & 0.39 & 0.82 & 0.29 & 0.65 & 30.30 & 20.90 & 18.30 & 8.31 \\
\hline Ho & 0.43 & 0.25 & 0.13 & 0.17 & 0.07 & 0.15 & 0.05 & 0.12 & 5.41 & 3.78 & 3.28 & 1.59 \\
\hline $\mathrm{Er}$ & 1.23 & 0.73 & 0.36 & 0.48 & 0.17 & 0.42 & 0.14 & 0.34 & 14.70 & 9.82 & 8.51 & 4.50 \\
\hline $\mathrm{Tm}$ & 0.18 & 0.12 & 0.05 & 0.07 & 0.00 & 0.06 & 0.00 & 0.05 & 1.97 & 1.22 & 1.10 & 0.65 \\
\hline $\mathrm{Yb}$ & 1.17 & 0.82 & 0.33 & 0.48 & 0.11 & 0.39 & 0.12 & 0.28 & 11.00 & 7.12 & 6.29 & 4.15 \\
\hline $\mathrm{Lu}$ & 0.18 & 0.13 & 0.05 & 0.08 & 0.02 & 0.06 & 0.02 & 0.04 & 1.57 & 1.02 & 0.90 & 0.66 \\
\hline $\mathrm{U}$ & 0.09 & 0.03 & 0.07 & 0.10 & 0.01 & 0.08 & 0.08 & 0.03 & 0.11 & 0.29 & 0.30 & 0.18 \\
\hline Th & 0.14 & 0.27 & 0.35 & 0.25 & 0.05 & 0.10 & 0.18 & 0.13 & 0.24 & 1.04 & 0.63 & 0.37 \\
\hline $\mathrm{Y}$ & 11.60 & 7.10 & 3.50 & 4.60 & 1.80 & 4.20 & 1.40 & 3.50 & 147.0 & 92.1 & 87.4 & 44.7 \\
\hline $\mathrm{Nb}$ & 16.4 & 8.5 & 1.4 & 4.5 & 1.2 & 3.5 & 0.8 & 2.4 & 58.3 & 19.0 & 19.5 & 24.4 \\
\hline $\mathrm{Zr}$ & 51 & 30 & 40 & 54 & 4 & 6 & 6 & 21 & 232 & 157 & 150 & 42 \\
\hline $\mathrm{Hf}$ & 1.1 & 0.7 & 0.9 & 1.3 & 0.1 & 0.3 & 0.2 & 0.5 & 8.2 & 5.3 & 5.2 & 1.2 \\
\hline $\mathrm{Ta}$ & 1.20 & 0.59 & 0.14 & 0.34 & 0.02 & 0.15 & 0.05 & 0.15 & 3.18 & 1.55 & 1.39 & 1.54 \\
\hline Sc & 8 & 8 & 1 & 4 & 1 & 2 & 1 & 2 & 51 & 55 & 58 & 23 \\
\hline $\mathrm{Ga}$ & 20 & 20 & 18 & 21 & 22 & 21 & 21 & 25 & 27 & 26 & 26 & 22 \\
\hline $\mathrm{Ni}$ & 20 & 20 & 20 & 20 & 20 & 20 & 20 & 20 & 40 & 20 & 30 & 30 \\
\hline Co & 11 & 12 & 1 & 5 & 1 & 3 & 1 & 2 & 27 & 23 & 21 & 26 \\
\hline $\mathrm{Cr}$ & 70 & 100 & 20 & 30 & 20 & 20 & 40 & 30 & 20 & 20 & 20 & 20 \\
\hline $\mathrm{Pb}$ & 5 & 5 & 5 & 5 & 5 & 5 & 5 & 5 & 5 & 5 & 5 & 5 \\
\hline \multicolumn{13}{|c|}{ Nd isotope data** } \\
\hline Sm (ppm & 2.49 & & & & & & 0.48 & & & 25.2 & & \\
\hline Nd (ppm) & 12.6 & & & & & & 3.1 & & & 111.0 & & \\
\hline${ }^{147} \mathrm{Sm} /{ }^{144} \mathrm{Nd}$ & 0.1195 & & & & & & 0.0933 & & & 0.0997 & & \\
\hline${ }^{143} /{ }^{144} \mathrm{Nd}$ & 0.512219 & & & & & & 0.511939 & & & 0.512332 & & \\
\hline$\varepsilon N d t$ & 2.4 & & & & & & 0.5 & & & 2.2 & & \\
\hline
\end{tabular}

All Sample Nos. have the prefix MAZ.

Minor elements determined by ICP-MS spectrometry.

*Analyses carried out by ACTL major elements determined by ICP spectrometry.

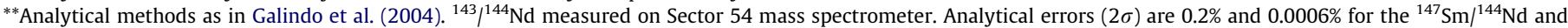
${ }^{143} /{ }^{144} \mathrm{Nd}$, respectively.

Analytical errors $(2 \sigma)$ are $0.2 \%$ and $0.0006 \%$ for the ${ }^{147} \mathrm{Sm} /{ }^{144} \mathrm{Nd}$ and ${ }^{143} /{ }^{144} \mathrm{Nd}$, respectively.

N-MORB these rocks are enriched in LILE and LREE (Fig. 5c) and have high abundances of HFSE elements, particularly the most acidic sample (MAZ12017, $\mathrm{SiO}_{2}=54 \%, \mathrm{Nb}=65 \mathrm{ppm}$, and $\mathrm{Ta}=3.9 \mathrm{ppm}$, Table 1$)$.

\subsection{Sierra de Pie de Palo}

The geochemistry and Nd isotope composition of the orthogneisses and mafic units from Sierra de Pie de Palo (Fig. 3) are based on of 12 new analyses (Table 3, Data Repositary) and previous results reported by Vujovich and Kay (1998) and Vujovich et al. (2004).

\subsubsection{The oceanic arc/back-arc complex}

In the lower mafic-ultramafic unit of Sierra de Pie de Palo (Fig. 3), amphibolites with N-MORB, back-arc like, geochemical signatures are common (pattern field, Fig. 9a and b) (Vujovich and Kay, 1998). However, both in the lower unit and in the overlaying imbricate thrust domain, there are also abundant subalkaline amphibolites and metagabbros that do not display the same geochemical characteristics (calcic field, Fig. 8). These latter rocks, including the SHRIMP-analysed gabbro sample SPP2067, show $\mathrm{SiO}_{2}=44.5-53.3 \%, \mathrm{~K}_{2} \mathrm{O}=0.2-1.1 \%, \mathrm{Al}_{2} \mathrm{O}_{3} 11.4-17.1 \%$ and REE pat terns with $[\mathrm{La} / \mathrm{Yb}]_{\mathrm{N}}=0.6-2.7$ and $\mathrm{Eu} / \mathrm{Eu}^{*}=0.75-1.06$ ) (Table 3, Fig. 9a). Normalized against N-MORB they are enriched in LILE, 

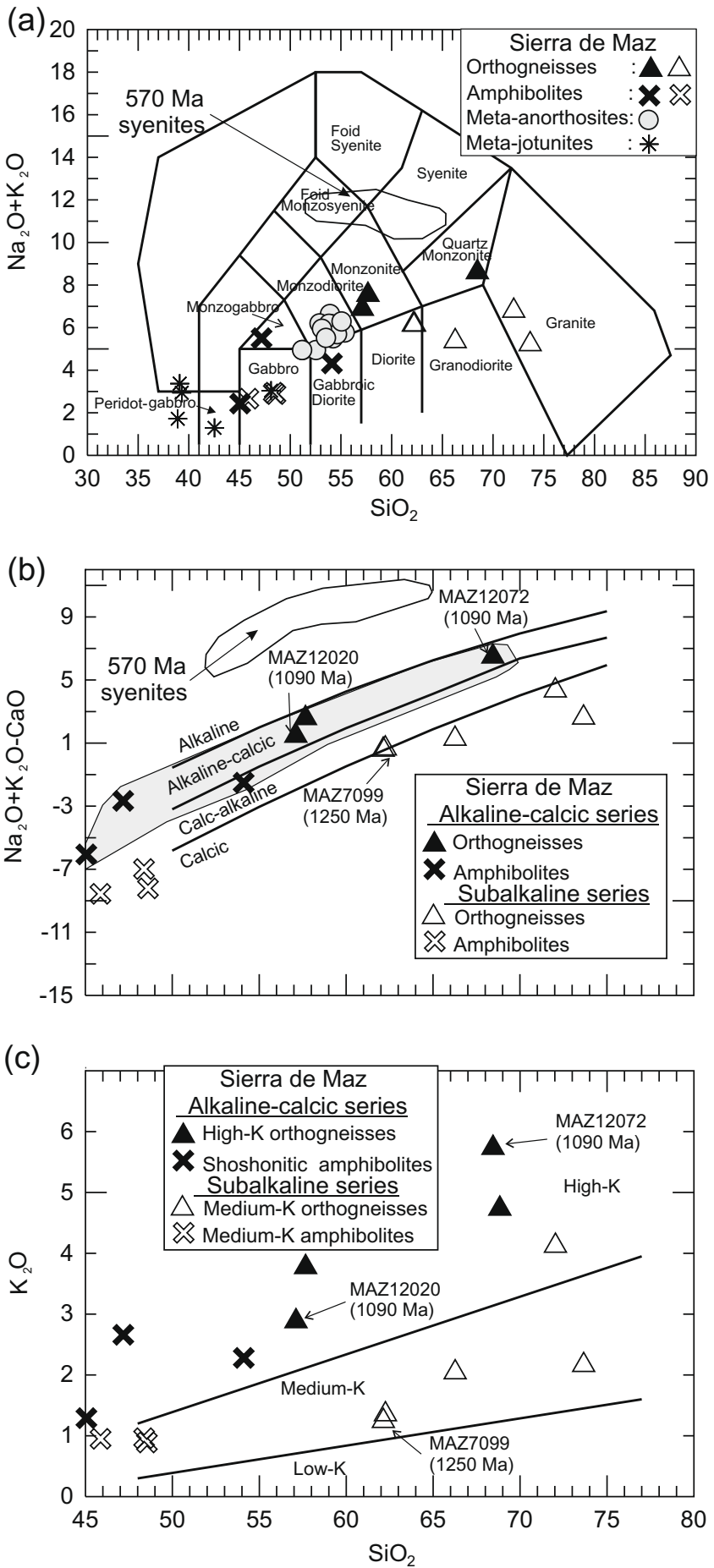

Fig. 4. Harker plots for the meta-igneous rocks of Sierra de Maz. Dividing lines and fields are from: (a) Middlemost (1997), (b) Frost et al. (2001), and (c) Le Maitre (1989). Identified samples in (b) and (c) are those with U-Pb SHRIMP ages determined in this study.

Th and LREE elements, which is taken as evidence that they formed in a supra-subduction zone environment, although they do not show the Nb depletion of many arc basalts (Fig. 9b). The pattern of the $1204 \pm 5$ Ma VL38 metagabbro dated by Vujovich et al. (2004) is also shown for comparison. A depleted mantle source is inferred for the calcic arc-related amphibolites and metagabbros $(\varepsilon N d t=+4.5$ to +8 , Fig. 6$)$. This suggests that the lower mafic-ultramafic unit is probably built on complex stacking of arc and backarc rocks (Vujovich and Kay, 1998).
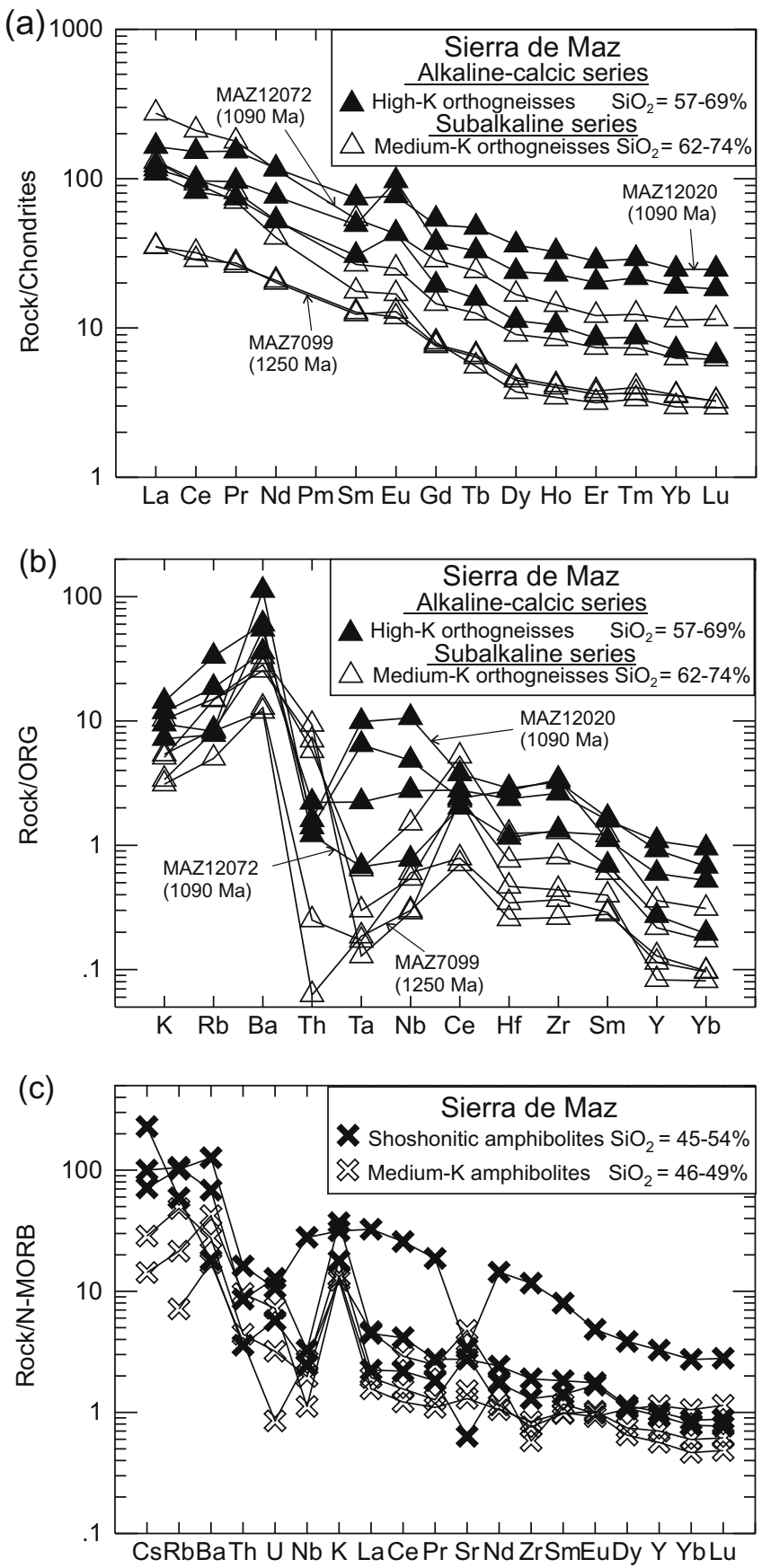

Fig. 5. Trace-element abundances in meta-igneous rocks of Sierra de Maz normalized to (a) chondrites (Nakamura, 1974), (b) ocean ridge granite (ORG, Pearce et al., 1984), and (c) N-MORB (Sun and McDonough, 1989). Identified samples in (a) and (b) are those with U-Pb SHRIMP ages determined in this study.

\subsubsection{Arc-related calc-alkaline orthogneisses}

Subordinate and sparse outcrops of a calc-alkaline orthogneiss series can be distinguished in Sierra de Pie de Palo. The dated sample SPP6076 is a calc-alkaline orthogneiss (Fig. 8) that shows a moderately steep REE pattern $\left([\mathrm{La} / \mathrm{Yb}]_{\mathrm{N}}=12.5\right)$ with well-developed middle REE depletion and a weak negative Eu anomaly, suggesting amphibole and feldspar fractionation (Fig. 10a). It is enriched in LREE and $\mathrm{Ba}$, and shows negative $\mathrm{Nb}$ and $\mathrm{Sr}$ anomalies when normalized against N-MORB (Fig. 10b). The $1108 \pm 13 \mathrm{Ma}$ calc-alkaline orthogneisses from Sierra de Umango studied by Varela et al. (2003) show similar but even steeper REE patterns (Fig. 10b), suggesting equilibration with a garnet-bearing residue. 

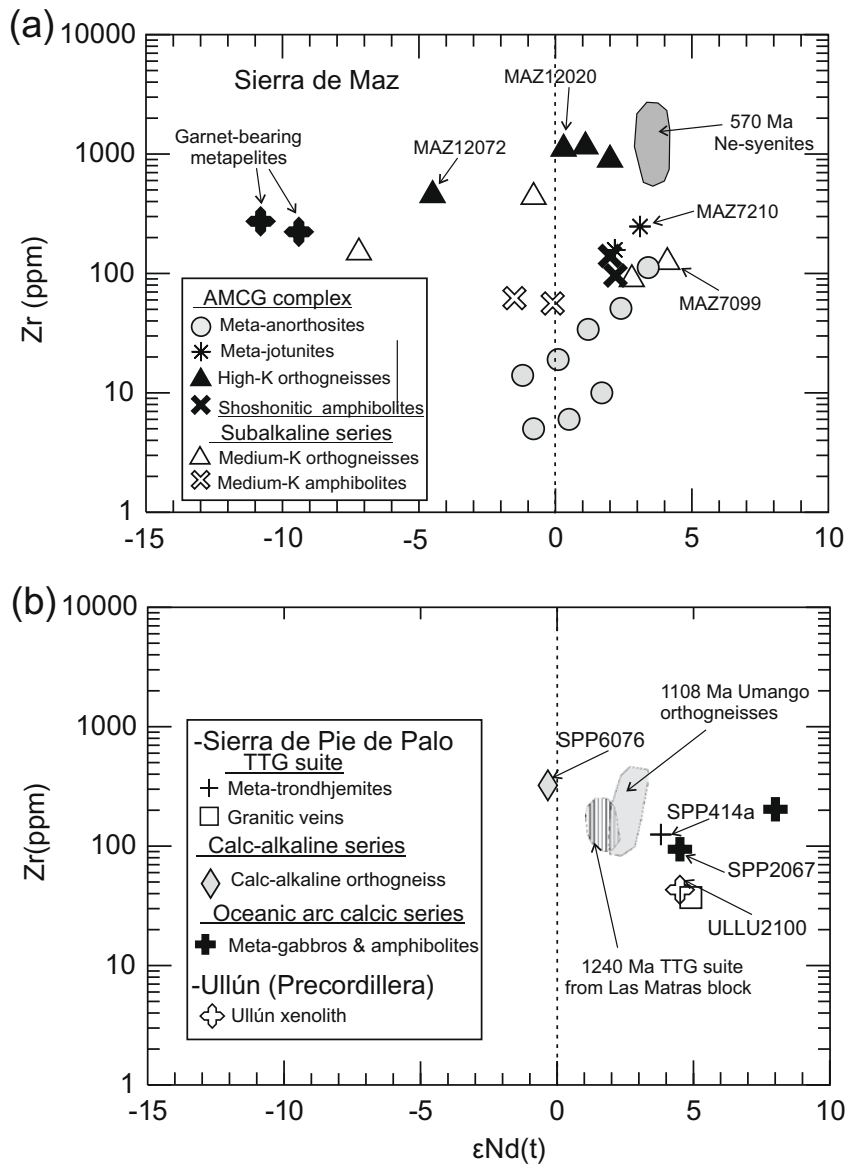

Fig. 6. Variation of $\varepsilon N d t$ vs $\log \mathrm{Zr}$ (ppm) for (a) the meta-igneous rocks of Sierra de Maz and (b) meta-igneous rocks of Sierra de Pie de Palo, an Ullún xenolith (Precordillera). Garnet-bearing metapelites and the field for 570 Ma Ne-syenites of Sierra de Maz are from Casquet et al. (2008a,b), respectively. Identified samples in (a) and (b) are those with U-Pb SHRIMP ages determined in this study. The age and $\mathrm{Zr}$ content of the jotunite MAZ7210 is from Casquet et al. (2004). The field for the TTG rocks of Las Matras block is from Sato et al. (2000), while the field of the Umango orthogneisses is from Varela et al. (2003).

Subduction under more mature crust is the preferred tectonic environment for this magmatism, which shows the least juvenile $\mathrm{Nd}$ isotope signature in this sierra $(\varepsilon \mathrm{Ndt}=-0.2$, Fig. $6 \mathrm{~b})$.

\subsubsection{The Mogote-Corralito TTG suite}

At the top of Sierra de Pie de Palo, within the imbricate thrust domain, a distinct sequence of metaluminous meta-trondhjemites and meta-tonalites forms the dominant lithology (Quebrada Mogote-Corralito, Fig. 3), with $\mathrm{SiO}_{2}$ 73.6-77.1\%, $\mathrm{Na}_{2} \mathrm{O}, 4.9-5.1 \%$, $\mathrm{FeOt}+\mathrm{MgO} 2.5-3.3 \%$, REE patterns with $[\mathrm{La} / \mathrm{Yb}]_{\mathrm{N}}=2.3-3.0$ and $\mathrm{a}$ negative Eu anomaly $\left(\mathrm{Eu} / \mathrm{Eu}^{*}=0.56-0.72\right)$ (Table 3, Fig. 10c). Associated leucocratic granitic veins that plot on the same $\mathrm{Rb}-\mathrm{Sr}$ isochron (Pankhurst and Rapela, 1998), show a negative slope of the REE patterns (Fig. 10c), suggesting fractionation of a LREE-rich accessory mineral such as allanite during the late crystallization stages. Allanite is an accessory mineral in the host trondhjemites. A mantle signature is indicated by the low ${ }^{87} \mathrm{Sr} /{ }^{86} \mathrm{Sr}$ initial ratio (0.7045, Pankhurst and Rapela, 1998), which is confirmed by a juvenile $\varepsilon N d t$ of +3.8 for the meta-trondhjemite sample dated by $\mathrm{U}-\mathrm{Pb}$ SHRIMP in this study (SPP414a, Fig. 6). Generation of this TTG suite in an arc environment is consistent with the low abundances of HFSE such as $\mathrm{Nb}$ and $\mathrm{Ta}$, low $\mathrm{Ga} / \mathrm{Al}$ ratio $\left(1000^{*} \mathrm{Ga}\right.$ / $\mathrm{Al}=0.7-2.2$ ) and low $\mathrm{Sr} / \mathrm{Y}$ (3.7-4.0) (Table 3), while the low [La/ $\mathrm{Yb}]_{\mathrm{N}}$ ratios suggest a source outside the garnet stability field. Note
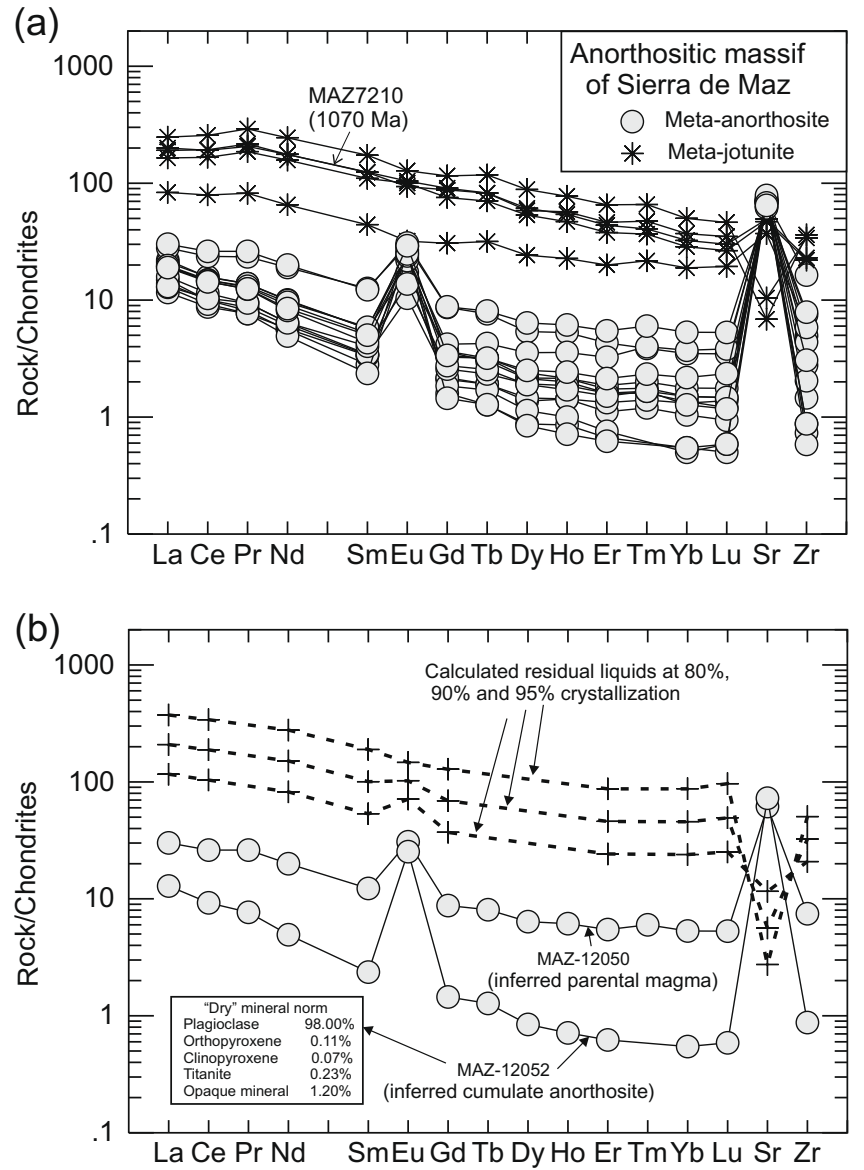

Fig. 7. (a) Chondrite-normalized REE, Sr and $\mathrm{Zr}$ patterns of meta-anorthosites and jotunites from Sierra de Maz (data from Table 2 and Casquet et al., 2004), (b) modelled residual liquids formed by Rayleigh fractional crystallization of a parental anorthosite (main facies, sample MAZ12050, Table 2) and an extracted cumulate assemblage represented by the leucocratic anorthosite MAZ12052. See text for further details. The jotunite MAZ7210 is from Casquet et al. (2004).

that the $1244 \pm 42$ Ma metaluminous tonalites and trondhjemites from Las Matras block (Fig. 1, Sato et al., 2000, 2004) show similar but slightly steeper REE patterns $[\mathrm{La} / \mathrm{Yb}]_{\mathrm{N}}=3.7-5.5$ (Sato et al., 2000) (Fig. 10c).

\subsection{Precordillera basement: the Ullún xenoliths}

The chemical analysis of a SHRIMP-dated foliated mafic xenolith enclosed in a Miocene dacite intruded in the Precordillera (sample ULLU2100, Fig. 3) is shown in Table 3 (data repository) and Figs. 6b, $8 c$ and 9c. Relative to the compositions of the xenolith groups recognized in the same outcrops by Kay et al. (1996), the major and trace element abundances of sample ULLU2100 are very similar to the least siliceous samples of the mafic amphibolite group $\left(\mathrm{SiO}_{2}=47.7-50.9 \%\right.$, Figs. $8 \mathrm{c}$ and $\left.9 \mathrm{c}\right)$, while the $\varepsilon \mathrm{Ndt}(+4.5)$ is slightly less primitive than those of the most mafic amphibolites $(+3.2$ to +3.5 , Table 4 of Kay et al., 1996). Altogether these characteristics point to relatively unfractionated mantle-derived arc magmatic rocks for the protoliths of the amphibolites, as was first inferred by Abruzzi et al. (1993).

It is worth pointing out that a more siliceous mafic amphibolite xenolith sample described by Kay et al. (1996) (UZ93B, $\mathrm{SiO}_{2}=53.4 \%, \varepsilon \mathrm{Nd}_{\mathrm{t}}=+2.1,1102 \pm 6 \mathrm{Ma}$ ) (Fig. 8c), shows a distinct, steeper, REE pattern (Fig. 9c) that resembles that of the roughly coeval calc-alkalic orthogneiss of Sierra de Pie de Palo (SPP6076, $\mathrm{SiO}_{2}=68.2 \%, \varepsilon \mathrm{Nd}_{\mathrm{t}}=-0.2,1110 \pm 10 \mathrm{Ma}$ ) (Fig. $10 \mathrm{a}$ and $\mathrm{b}$ ), which is 
Table 3

Geochemical and isotope data of Sierra de Pie de Palo and Ullum xenolith (Precordillera).

\begin{tabular}{|c|c|c|c|c|c|c|c|c|c|c|c|c|}
\hline \multirow[b]{4}{*}{$\begin{array}{l}\text { Sample } \\
\text { (wt\%) }\end{array}$} & \multicolumn{11}{|c|}{ Pie de Palo } & \multirow{4}{*}{$\begin{array}{l}\text { Ullum Xenolith } \\
\underset{* *}{2100}\end{array}$} \\
\hline & \multicolumn{4}{|c|}{ Oceanic arc rocks } & \multirow{2}{*}{\multicolumn{4}{|c|}{ Mogote-Corralito meta-trondhjemites }} & \multirow{2}{*}{\multicolumn{2}{|c|}{ Granitic veins }} & \multirow{2}{*}{$\begin{array}{l}\text { Calc-alkaline } \\
\text { orthogneiss }\end{array}$} & \\
\hline & \multicolumn{2}{|c|}{ Amphibolites } & \multicolumn{2}{|c|}{ Metagabbro } & & & & & & & & \\
\hline & $\begin{array}{l}429 \\
*\end{array}$ & $\begin{array}{l}423 \\
*\end{array}$ & $\begin{array}{l}427 \\
*\end{array}$ & $\begin{array}{l}2067 \\
* *\end{array}$ & $\begin{array}{l}412 \\
*\end{array}$ & $\begin{array}{l}414 a \\
*\end{array}$ & $\begin{array}{l}411 \\
*\end{array}$ & $\begin{array}{l}416 \\
*\end{array}$ & $\begin{array}{l}413 \\
*\end{array}$ & $\begin{array}{l}414 \mathrm{~b} \\
*\end{array}$ & $\begin{array}{l}6076 \\
* *\end{array}$ & \\
\hline $\mathrm{SiO}_{2}$ & 44.5 & 47.58 & 47.98 & 53.25 & 73.64 & 74.11 & 76.36 & 77.15 & 73.61 & 74.92 & 68.24 & 50.12 \\
\hline $\mathrm{TiO}_{2}$ & 3.17 & 1.07 & 2.11 & 0.81 & 0.19 & 0.21 & 0.17 & 0.17 & 0.01 & 0.02 & 0.52 & 0.70 \\
\hline $\mathrm{Al}_{2} \mathrm{O}_{3}$ & 11.35 & 16.16 & 12.98 & 17.07 & 12.48 & 12.32 & 12.2 & 11.92 & 14.04 & 14.16 & 15.31 & 14.08 \\
\hline $\mathrm{Fe}_{2} \mathrm{O}_{3} \mathrm{t}$ & 20.81 & 11.79 & 16.01 & 7.79 & 2.87 & 3.52 & 2.78 & 2.73 & 0.35 & 0.72 & 4.36 & 10.05 \\
\hline $\mathrm{MnO}$ & 0.33 & 0.18 & 0.26 & 0.14 & 0.1 & 0.11 & 0.07 & 0.08 & 0.03 & 0.07 & 0.09 & 0.22 \\
\hline $\mathrm{MgO}$ & 7.61 & 8.86 & 6.07 & 6.69 & 0.13 & 0.16 & 0.19 & 0.1 & 0.01 & 0.01 & 0.95 & 8.18 \\
\hline $\mathrm{CaO}$ & 9.5 & 10.18 & 9.46 & 9.08 & 1.64 & 1.71 & 1.45 & 1.29 & 0.95 & 0.98 & 2.48 & 9.21 \\
\hline $\mathrm{Na}_{2} \mathrm{O}$ & 1.71 & 2.88 & 2.48 & 3.27 & 5.08 & 4.97 & 4.89 & 5.11 & 5.2 & 4.85 & 3.48 & 3.06 \\
\hline $\mathrm{K}_{2} \mathrm{O}$ & 0.24 & 0.73 & 0.79 & 1.1 & 1.49 & 1.51 & 1.81 & 1.43 & 4 & 4.34 & 4.37 & 1.24 \\
\hline $\mathrm{P}_{2} \mathrm{O} 5$ & 0.21 & 0.11 & 0.21 & 0.11 & 0.04 & 0.05 & 0.04 & 0.03 & 0.01 & 0.01 & 0.21 & 0.57 \\
\hline LOI & 1.31 & 1.08 & 0.56 & 0.91 & 0.28 & 0.22 & 0.24 & 0.24 & 0.28 & 0.34 & 0.82 & 2.20 \\
\hline Total (ppm)* & 100.74 & 100.62 & 98.91 & 100.22 & 97.94 & 98.89 & 100.2 & 100.25 & 98.49 & 100.42 & 100.83 & 99.63 \\
\hline Cs & 0.2 & 1.6 & 1.4 & 0.5 & 1.0 & 1.1 & 1.0 & 1.3 & 36.5 & 0.5 & 0.40 & 0.4 \\
\hline $\mathrm{Rb}$ & 1 & 11 & 39 & 28 & 45 & 41 & 62 & 28 & 97 & 88 & 97 & 25 \\
\hline $\mathrm{Sr}$ & 95 & 223 & 95 & 289 & 131 & 122 & 117 & 100 & 91 & 105 & 210 & 755 \\
\hline $\mathrm{Ba}$ & 90 & 95 & 162 & 242 & 330 & 370 & 500 & 450 & 420 & 326 & 1222 & 212 \\
\hline La & 8.90 & 3.60 & 7.00 & 9.24 & 10.70 & 11.80 & 10.50 & 13.00 & 1.80 & 1.60 & 50.60 & 7.73 \\
\hline $\mathrm{Ce}$ & 26.0 & 11.0 & 25.0 & 22.6 & 25.0 & 28.0 & 24.0 & 32.0 & 6.0 & 6.0 & 100.0 & 16.60 \\
\hline $\operatorname{Pr}$ & n.d & n.d & n.d & 3.37 & n.d & n.d & n.d & n.d & n.d & n.d & 11.90 & 2.94 \\
\hline $\mathrm{Nd}$ & 18.00 & 8.00 & 18.00 & 14.20 & 14.00 & 16.00 & 13.00 & 16.00 & 4.00 & 3.00 & 39.50 & 12.60 \\
\hline $\mathrm{Sm}$ & 5.02 & 2.40 & 6.15 & 3.59 & 3.53 & 3.70 & 2.96 & 4.06 & 1.08 & 0.91 & 7.20 & 3.33 \\
\hline $\mathrm{Eu}$ & 1.65 & 0.94 & 1.85 & 1.34 & 0.78 & 0.86 & 0.65 & 0.78 & 0.39 & 0.37 & 1.60 & 0.95 \\
\hline Gd & n.d & n.d & n.d & 4.04 & n.d & n.d & n.d & n.d & n.d & n.d & 6.00 & 3.26 \\
\hline $\mathrm{Tb}$ & 1.10 & 0.60 & 1.70 & 0.67 & 0.80 & 0.70 & 0.50 & 0.70 & 0.40 & 0.30 & 0.89 & 0.51 \\
\hline Dy & n.d & n.d & n.d & 4.12 & n.d & n.d & n.d & n.d & n.d & n.d & 4.93 & 2.96 \\
\hline Ho & n.d & n.d & n.d & 0.85 & n.d & n.d & n.d & n.d & n.d & n.d & 0.96 & 0.60 \\
\hline $\mathrm{Er}$ & n.d & n.d & n.d & 2.48 & n.d & n.d & n.d & n.d & n.d & n.d & 2.81 & 1.83 \\
\hline $\mathrm{Tm}$ & n.d & n.d & n.d & 0.35 & n.d & n.d & n.d & n.d & n.d & n.d & 0.42 & 0.27 \\
\hline $\mathrm{Yb}$ & 4.07 & 2.49 & 7.95 & 2.17 & 2.73 & 3.32 & 2.49 & 2.95 & 3.29 & 2.70 & 2.66 & 1.69 \\
\hline $\mathrm{Lu}$ & 0.60 & 0.37 & 1.18 & 0.31 & 0.41 & 0.50 & 0.36 & 0.46 & 0.51 & 0.42 & 0.38 & 0.24 \\
\hline $\mathrm{U}$ & 0.40 & 0.10 & 0.10 & 0.83 & 0.90 & 0.80 & 0.50 & 0.40 & 0.50 & 1.60 & 2.38 & 0.99 \\
\hline Th & 0.70 & 0.20 & 0.70 & 0.87 & 2.10 & 1.30 & 1.10 & 1.40 & 3.40 & 2.50 & 12.00 & 0.45 \\
\hline $\mathrm{Y}$ & 43.00 & 25.00 & 72.00 & 23.20 & 33.00 & 34.00 & 29.00 & 28.00 & 28.0 & 28.0 & 28.9 & 18.9 \\
\hline $\mathrm{Nb}$ & 6.0 & 8.0 & 10.0 & 5.5 & 4.0 & 2.0 & 2.0 & 2.0 & 2.0 & 2.0 & 10.3 & 5.7 \\
\hline $\mathrm{Zr}$ & 203 & 78 & 173 & 94 & 128 & 125 & 135 & 149 & 37 & 83 & 314 & 43 \\
\hline $\mathrm{Hf}$ & 4.1 & 1.6 & 4.4 & 2.4 & 3 & 3.3 & 2.8 & 3.5 & 0.9 & 2 & 7.3 & 1.7 \\
\hline $\mathrm{Ta}$ & 0.30 & 0.30 & 0.30 & 0.32 & 0.30 & 0.30 & 0.60 & 0.30 & 0.30 & 0.30 & 0.58 & 0.66 \\
\hline Sc & 46 & 37 & 48 & 27 & 12 & 12 & 8 & 10 & 3 & 1 & 8 & 36 \\
\hline $\mathrm{Ga}$ & 16 & 10 & 9 & 16 & 15 & 15 & 5 & 14 & 18 & 19 & 18 & 14 \\
\hline $\mathrm{Ni}$ & 82 & 139 & 50 & 0 & 50 & 50 & 50 & 50 & 50 & 50 & 0 & 100 \\
\hline Co & 59 & 44 & 53 & 26 & 1 & 1 & 2 & 1 & 0.5 & 0.4 & 7 & 29 \\
\hline $\mathrm{Cr}$ & 177 & 121 & 123 & 380 & 80 & 57 & 67 & 62 & 37 & 17 & 15 & 290 \\
\hline $\mathrm{Pb}$ & n.d & n.d & n.d & 7 & n.d & n.d & n.d & n.d & n.d & n.d & 11 & 32 \\
\hline $\mathrm{Nd}$ isotope & $* * *$ & & & $* * *$ & & $* * *$ & & & $* * *$ & & $* * * *$ & $* * *$ \\
\hline Sm (ppm) & 5.02 & & & 3.41 & & 4.06 & & & 1.15 & & 7.2 & 4.53 \\
\hline $\mathrm{Nd}(\mathrm{ppm})$ & 18 & & & 13.69 & & 19.08 & & & 2.97 & & 39.5 & 18.03 \\
\hline${ }^{147} \mathrm{Sm} / 144 \mathrm{~N}$ & 0.1686 & & & 0.1505 & & 0.1459 & & & 0.2350 & & 0.1376 & 0.1520 \\
\hline${ }^{143} /{ }^{144} \mathrm{Ni}$ & 0.512827 & & & 0.512502 & & 0.512493 & & & 0.513146 & & 0.512201 & 0.512550 \\
\hline$\varepsilon \mathrm{Ndt}$ & 8 & & & 4.5 & & 3.8 & & & 4.9 & & -0.2 & 4.5 \\
\hline
\end{tabular}

Pie de Palo samples have the prefix SPP; the xenolith is ULLU2100.

Minor elements determined by INAA.

Analyses carried out by ACTLABS, Canada. Major elements determined by XRF

*** Major elements determined by ICP spectrometry. Minor elements dtermined by ICP-MS spectrometry.

${ }^{* * * *}$ Analytical methods as in Pankhurst and Rapela (1995): Sm and Nd by MS isotope dilution at NIGL: $( \pm 1 \%, 1 \sigma)^{143} /{ }^{144} \mathrm{Nd}$ measured on MAT $262( \pm 0.005 \%, 1 \sigma)$.

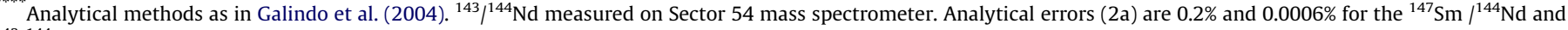
${ }^{143} /{ }^{144} \mathrm{Nd}$, respectively.

however more siliceous and does not show the typical high $\mathrm{Cr}$ and Ni contents of the mafic amphibolite xenolith group.

\section{U-Pb zircon geochronology}

\subsection{Samples and method}

Sampling for SHRIMP U-Pb zircon dating was designed to provide information on crystallization ages of the main magmatic ser- ies recognized in the sierras of Maz and Pie de Palo (Figs. 8-10), and of a xenolith interpreted as derived from the basement of the Precordillera (Fig. 8c and 10c). Under CL imaging the sectioned zircon grains were seen to have metamorphic overgrowths, so an additional aim was to constrain the timing of metamorphism. Sample localities are shown in the maps (Figs. 2 and 3); precise coordinates and a short description of the mineralogy and fabric for each sample are provided in the following section. Mineral abbreviations follow Kretz (1983). 

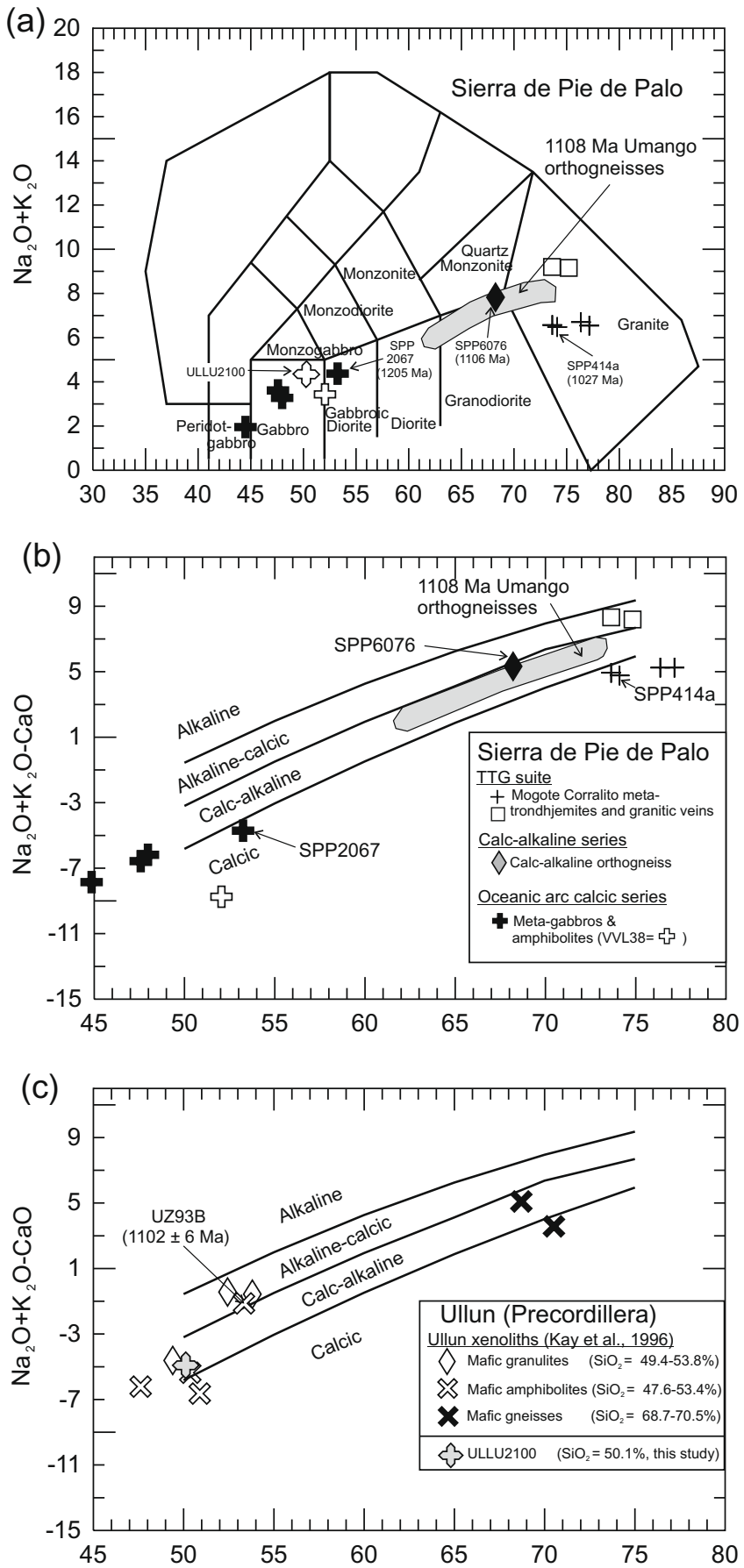

Fig. 8. Harker plots for the meta-igneous rocks of Sierra de Pie de Palo ( $a$ and $b$ ) and Ullún xenoliths in the Precordillera (c). Dividing lines and fields are from: (a) Middlemost (1997) and (b and c) Frost et al. (2001). Identified samples are those with U-Pb SHRIMP ages determined in this study, while metagabbro VV38 and shoshonite amphibolite PP10 from Sierra de Pie de Palo are from Vujovich et al. (2004) and Vujovich and Kay (1998), respectively. Ullún xenoliths from the Precordillera are from Kay et al. (1996). The field of Umango orthogneisses is from Varela et al. (2003).

The separated zircons were mounted in epoxy together with reference zircons, sectioned and polished. $\mathrm{U}-\mathrm{Th}-\mathrm{Pb}$ analyses were made using SHRIMP II or SHRIMP RG at the Research School of Earth Sciences, The Australian National University, Canberra, following methods given in Williams (1998) and references therein. Cathodo-luminescence $(\mathrm{CL})$ images were prepared for all zircon grains and were used to target specific areas for analysis. The data were processed using the SQUID Excel macro (Ludwig 2001). U-Pb
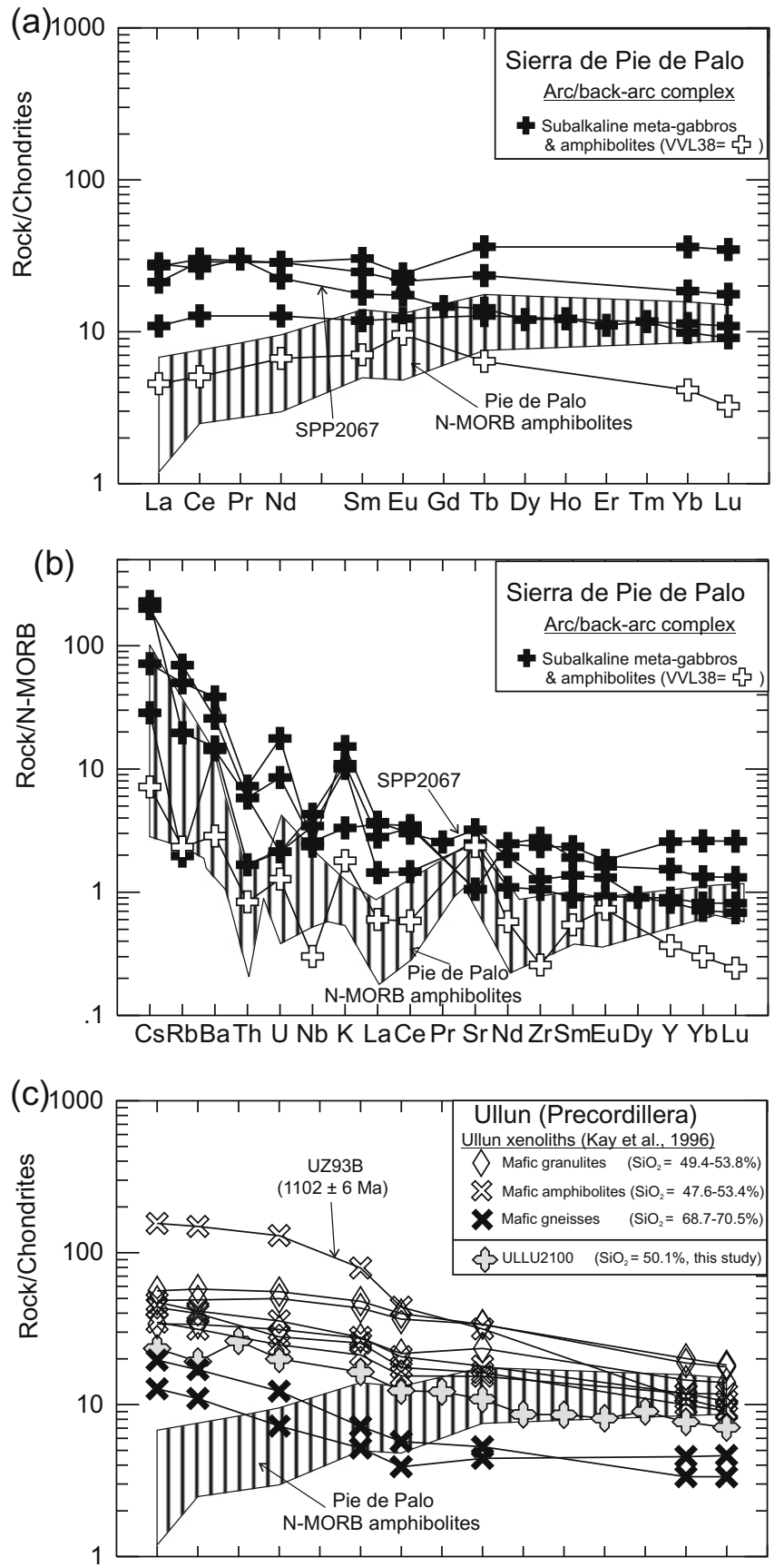

Fig. 9. (a) Trace element abundances in the arc/back-arc meta-igneous rocks of Sierra de Pie de normalized to chondrites (Nakamura, 1974), (b) Trace element abundances in the arc/back-arc meta-igneous rocks of Sierra de Pie de Palo normalized to N-MORB (Sun and McDonough, 1989). The fields of N-MORB amphibolites from Sierra de Pie de Palo in (a) and (b) are from Vujovich and Kay (1998), and (c) Trace elements abundances in the Ullún xenoliths of the Precordillera and U-Pb dated xenolith UZ93B are after Kay et al. (1996). The field of NMORB amphibolites from Sierra de Pie de Palo is that of Vujovich and Kay (1998). Identified samples are those with U-Pb SHRIMP ages determined in this study, while metagabbro VV38 from Sierra de Pie de Palo is from Vujovich et al. (2004).

data are given in Table 4 (data repository); details of the reference zircons used to calibrate the $\mathrm{U} / \mathrm{Pb}$ ratios and the calibration uncertainties are also given in data repository tabulations. Uncertainties in Table 4 for individual analyses (ratios and ages) are at the onesigma level.

Wetherill Concordia plots, probability density plots with stacked histograms, and weighted mean and Concordia age calculations were carried out using Isoplot/Ex (Ludwig, 2003); age 

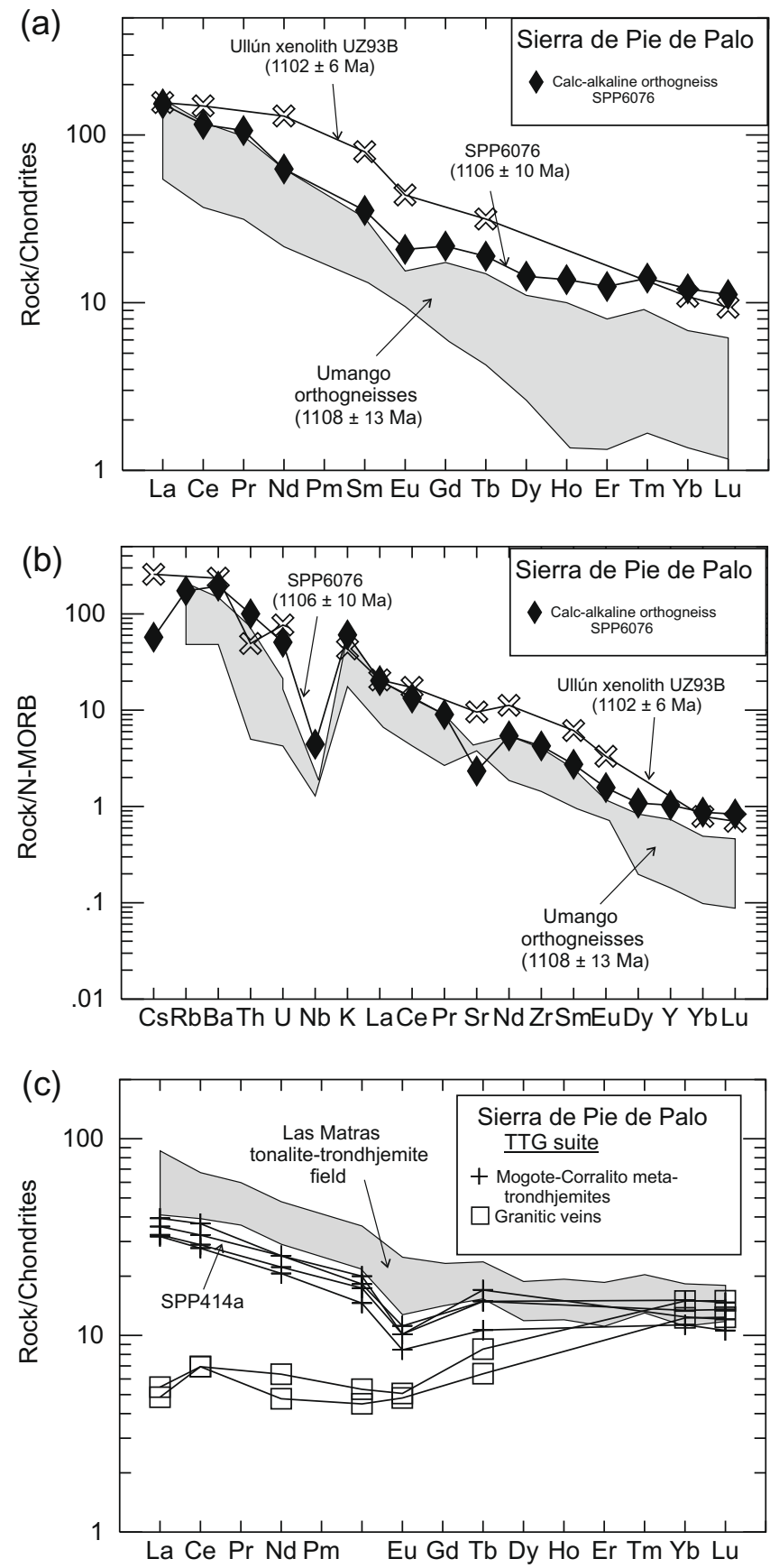

Fig. 10. (a) Trace element abundances in calc-alkaline meta-igneous rocks of Sierra de Pie de Palo normalized to chondrites (Nakamura, 1974) and (b) N-MORB (Sun and McDonough, 1989). The fields of Umango orthogneisses are from Varela et al. (2003) and the Ullún xenolith is from Kay et al. (1996). (c) Trace element abundances in meta-trondhjemites and related granitic veins from Sierra de Pie de Palo normalized to chondrites. The field for the $1244 \pm 42 \mathrm{Ma}$ tonalite-trondhjemites from Las Matras block (Fig. 1) is from Sato et al. (2000). Identified samples are those with U-Pb SHRIMP ages determined in this study.

uncertainties are reported as $95 \%$ confidence limits. In some cases, the "mixture modelling" algorithm of Sambridge and Compston (1994) was used (via Isoplot/Ex) to statistically separate age populations or groupings. Due to the difficulty in determining precise, common $\mathrm{Pb}$ corrected, radiogenic ${ }^{207} \mathrm{~Pb} /{ }^{206} \mathrm{~Pb}$ ratios for ca. $1 \mathrm{Ga}$ zircons by SHRIMP, a range of techniques was employed to calculate individual best age estimates. The choice of technique was based on factors such as the $U$ content of the zircon area analysed (which flows onto the amount of radiogenic ${ }^{207} \mathrm{~Pb}$ ), the ability to detect
${ }^{204} \mathrm{~Pb}$, the strength of the primary ion beam used for the analysis, and whether the area analysed is considered to have lost radiogenic $\mathrm{Pb}$, etc. This is discussed below on a sample-by-sample basis.

\subsection{Analytical results}

MAZ7099, Sierra de Maz $\left(29^{\circ} 16^{\prime} 06.4^{\prime \prime}, 68^{\circ} 21^{\prime} 09.1^{\prime \prime}\right)$. This sample is a subalkaline, medium-K, metadioritic orthogneiss (Fig. 4); its main mineralogy is $\mathrm{Pl}-\mathrm{Qtz}-\mathrm{Hbl}-\mathrm{Cpx}-\mathrm{Bt}-\mathrm{Ttn}-\mathrm{Ep}$, with accessory $\mathrm{Op}, \mathrm{Ap}$, and Zrn. The original granular igneous fabric is still preserved, but an amphibolite-facies coronitic texture with Cpx, Anf, $\mathrm{Pl}$, and myrmekitic Ep is also well developed. Zircons are large ( $\sim 200 \mu \mathrm{m}$ across) and sub-round to somewhat elongated, often with faceted forms. A summary of the initial results was presented by Casquet et al. (2005) but a re-interpretation is presented here, taking into account a larger database.

The zircons from this sample show complex internal structure under CL (Fig. 11). In general the grains have an igneous component that shows weak oscillatory zoning (as core/centres), which in places is overgrown by a sector-zoned zircon component reflecting a high-grade metamorphic paragenesis. Some grains are dominated by the metamorphic zircon component. A few grains have thin bright luminescent rims that are significantly less than $10 \mathrm{mi}-$ crons in width and so difficult to analyse.

The analyses cluster close to or within uncertainty of Concordia (Wetherill plot) and have ${ }^{207} \mathrm{~Pb} /{ }^{206} \mathrm{~Pb}$ ages ranging from ca. 980 to ca. $1290 \mathrm{Ma}$. The U content is variable, ranging up to $300 \mathrm{ppm}$, but many areas analysed have less than $44 \mathrm{ppm}$ U. The Th content is covariant and, whilst the $\mathrm{CL}$ images indicate a metamorphic paragenesis, the $\mathrm{Th} / \mathrm{U}$ ratios are in the range of normal igneous zircon (ca. 0.4-0.8). This suggests that the high-grade metamorphic zircon growth has occurred without significant Th depletion, a feature that has been documented previously (see Goodge et al., 2001). The low $\mathrm{U}$ contents make it difficult to determine precise ${ }^{207} \mathrm{~Pb} /{ }^{206} \mathrm{~Pb}$ ratios and ages. Given the general concordance of the analyses, our preferred treatment of this low $U$ data-set is based on the radiogenic ${ }^{206} \mathrm{~Pb} /{ }^{238} \mathrm{U}$ ages, as shown in the probability density plot (inset Fig. 11). There is a poorly defined older grouping of dates, with one peak at about $1260 \mathrm{Ma}$ and a subordinate one at about $1330 \mathrm{Ma}$. These generally correspond to the core analyses and are taken reflecting the time of igneous crystallization of the orthogneiss protolith. Two younger groupings are better defined as discrete events, one at ca. $1175 \mathrm{Ma}$ and a younger at ca.1095 Ma. These younger ages are interpreted as representing metamorphic events, the older of which was probably at rather high-grade on the basis of the metamorphic zircon morphology.

MAZ12020, Sierra de Maz $\left(29^{\circ} 15^{\prime} 37.3^{\prime \prime}, 68^{\circ} 22^{\prime} 19.6^{\prime \prime}\right)$. This is an alkali-calcic, high-K meta-monzonitic (meta-mangerite) orthogneiss (Fig. 4b and c). Its main mineralogy is Pl-Hbl-Grt-Qtz $(<20 \%)-\mathrm{Bt}$, with accessory Ttn, Czo, Ilm, Zrn, and Ap. The metamorphic assemblage $\mathrm{Grt}+\mathrm{Bt}+\mathrm{Pl}+\mathrm{Hbl}$ indicates garnet amphibolite facies conditions.

The zircons from this sample are notably elongate, subhedral grains, up to $400 \mu \mathrm{m}$ in length, most with sub-round terminations. Many grains have colourless inclusions of apatite. The CL images show either simple oscillatory zoning or areas with broad zones, sometimes rimmed by oscillatory zonation. These features are interpreted as reflecting a single igneous zircon crystallisation event. The 19 grains analysed, including cores and rims to three structured grains, yield concordant to near-concordant data (Fig. 12a, Table 4). Eighteen of the 21 areas analysed form a single concordant grouping to within analytical uncertainty, giving a Concordia age of $1092 \pm 6 \mathrm{Ma}$ (MSWD $=0.23$ ), which constrains the time of igneous zircon crystallisation. There is no evidence within these zircon grains for metamorphic growth. However the subhedral grain shape and sub-round nature of terminations suggests 
(a) Summary of SHRIMP U-Pb zircon results for sample MAZ7099

$\begin{array}{llllllll}2003 & \text { SHRIMP II } & & & & & & \\ 1.1 & 133 & 51 & 0.38 & 24.5 & 0.000117 & 0.19 & 4.663 \\ 2.1 & 300 & 176 & 0.59 & 50.9 & - & <0.01 & 5.060 \\ 3.1 & 24 & 12 & 0.52 & 4.5 & 0.000407 & 0.68 & 4.456 \\ 4.1 & 27 & 15 & 0.56 & 4.9 & 0.000310 & 0.52 & 4.703 \\ 4.2 & 25 & 13 & 0.53 & 3.8 & 0.000610 & 1.05 & 5.688 \\ 5.1 & 132 & 153 & 1.16 & 24.7 & 0.000114 & 0.19 & 4.600 \\ 5.2 & 48 & 20 & 0.42 & 8.5 & 0.000158 & 0.26 & 4.799 \\ 6.1 & 42 & 22 & 0.51 & 7.0 & 0.000305 & 0.51 & 5.209 \\ 6.2 & 18 & 10 & 0.54 & 2.5 & - & <0.01 & 6.033 \\ 7.1 & 26 & 14 & 0.55 & 3.9 & 0.000133 & 0.22 & 5.612 \\ 7.2 & 22 & 11 & 0.53 & 3.7 & 0.000115 & 0.19 & 5.015 \\ 8.1 & 19 & 10 & 0.49 & 3.1 & 0.000079 & 0.13 & 5.401 \\ 8.2 & 309 & 35 & 0.11 & 48.4 & 0.000001 & <0.01 & 5.479 \\ 9.1 & 17 & 8 & 0.50 & 2.7 & 0.000753 & 1.30 & 5.341 \\ 2008 & S H R I M P R G & & & & & & \\ 10.1 & 32 & 15 & 0.47 & 5.8 & 0.000473 & 0.80 & 4.785 \\ 3.2 & 87 & 40 & 0.46 & 15.0 & 0.000054 & 0.09 & 4.998 \\ 11.1 & 74 & 34 & 0.45 & 12.7 & 0.000291 & 0.49 & 5.043 \\ 11.2 & 115 & 91 & 0.80 & 19.9 & 0.000197 & 0.33 & 4.953 \\ 12.1 & 264 & 130 & 0.49 & 45.0 & 0.000026 & 0.04 & 5.044 \\ 12.2 & 49 & 34 & 0.69 & 9.7 & 0.000515 & 0.86 & 4.369 \\ 4.3 & 29 & 16 & 0.54 & 4.7 & 0.000601 & 1.02 & 5.349 \\ 13.1 & 195 & 109 & 0.56 & 31.0 & 0.000076 & 0.13 & 5.394 \\ 13.2 & 31 & 15 & 0.49 & 6.0 & 0.000628 & 1.05 & 4.443 \\ 14.1 & 33 & 17 & 0.52 & 5.5 & 0.001466 & 2.60 & 5.098 \\ 9.2 & 37 & 17 & 0.46 & 7.0 & 0.000962 & 1.64 & 4.530 \\ 15.1 & 22 & 11 & 0.51 & 3.6 & 0.000905 & 1.58 & 5.366 \\ 16.1 & 74 & 37 & 0.50 & 13.6 & 0.000345 & 0.58 & 4.652 \\ 17.1 & 58 & 46 & 0.79 & 11.0 & 0.000237 & 0.39 & 4.561 \\ 18.1 & 97 & 90 & 0.92 & 18.7 & 0.000179 & 0.30 & 4.479\end{array}$

$\begin{array}{ll}0.054 & 0.0848\end{array}$ $0.054 \quad 0.0796$ $\begin{array}{lll}0.076 & 0.0850\end{array}$ $0.077 \quad 0.0826$ $\begin{array}{ll}0.097 \quad 0.0797 \\ 0.053 & 0.0843\end{array}$ $\begin{array}{lll}0.053 & 0.0843\end{array}$ $0.075 \quad 0.0844$ $0.114 \quad 0.0795$ $\begin{array}{lll}0.093 & 0.0793\end{array}$ $\begin{array}{lll}0.093 & 0.0793\end{array}$ 0.0815 $0.059 \quad 0.0764$ $0.100 \quad 0.0785$

$\begin{array}{ll}0.087 & 0.0837\end{array}$ $0.066 \quad 0.0786$ $\begin{array}{ll}0.070 & 0.0824\end{array}$ $\begin{array}{lll}0.063 & 0.0808\end{array}$ $\begin{array}{ll}0.057 & 0.0809 \\ 0.068 & 0.0877\end{array}$ $\begin{array}{ll}0.068 & 0.0877\end{array}$ $\begin{array}{ll}0.101 & 0.0834 \\ 0.064 & 0.0783\end{array}$ $\begin{array}{ll}0.064 & 0.0783\end{array}$ $\begin{array}{ll}0.078 & 0.0877\end{array}$ $\begin{array}{ll}0.098 & 0.0809\end{array}$ $\begin{array}{ll}0.081 & 0.0859\end{array}$ $\begin{array}{ll}0.121 & 0.0788\end{array}$ $0.068 \quad 0.0855$ $0.071 \quad 0.0848$
0.061 $0.061 \quad 0.0840$

Error in $\mathrm{FC} 1$ reference zircon calibration was $0.43 \%$ \& $0.55 \%$ for the two analytical sessions.

(b) Summary of SHRIMP U-Pb zircon results for sample MAZ 12072.

$\begin{array}{lllll}1.1 & 84 & 52 & 0.62 & 13.1 \\ 2.1 & 298 & 161 & 0.54 & 46.6 \\ 3.1 & 527 & 187 & 0.36 & 80.2 \\ 4.1 & 116 & 105 & 0.91 & 18.3 \\ 5.1 & 111 & 104 & 0.93 & 17.1 \\ 6.1 & 56 & 53 & 0.94 & 8.8 \\ 7.1 & 77 & 74 & 0.96 & 12.0 \\ 8.1 & 73 & 103 & 1.41 & 11.1 \\ 9.1 & 108 & 59 & 0.55 & 16.8 \\ 14.1 & 95 & 81 & 0.85 & 14.8 \\ 12.2 & 264 & 128 & 0.49 & 43.8 \\ 15.1 & 87 & 87 & 1.00 & 13.4 \\ 16.1 & 114 & 137 & 1.21 & 17.2 \\ 17.1 & 199 & 97 & 0.49 & 30.6 \\ 17.2 & 90 & 61 & 0.68 & 14.5 \\ 18.1 & 69 & 54 & 0.79 & 11.2 \\ 19.1 & 83 & 59 & 0.71 & 12.7 \\ 20.1 & 126 & 74 & 0.59 & 20.6\end{array}$

$\begin{array}{lll}0.000148 & 0.25 & 5.520\end{array}$ $\begin{array}{lll}0.000013 & 0.02 & 5.505\end{array}$ $0.000032<0.01 \quad 5.650$ $0.000209 \quad 0.35 \quad 5.593$ $\begin{array}{ll}<0.01 & 5.484 \\ <0.01 & 5.474\end{array}$ $\begin{array}{llll}0.000154 & 0.26 & 5.663\end{array}$ $\quad<0.01 \quad 5.523$ $\begin{array}{lll}- & <.01 \quad 5.538 \\ 0.000859 & 1.45 & 5.173\end{array}$ $\begin{array}{lll}0.000859 & 1.45 & 5.173 \\ 0.000147 & 0.25 & 5.597\end{array}$ $\begin{array}{llll}0.000029 & 0.25 & 5.597\end{array}$ 0.00029 $\begin{array}{lll}0.0000052 & 0.09 & 5.583\end{array}$ $0.000068 \quad 0.11 \quad 5.287$ $0.000015 \quad 0.03 \quad 5.240$ $\begin{array}{ll}0.067 & 0.0772\end{array}$ $\begin{array}{ll}0.066 & 0.0762 \\ 0.059 & 0.0753\end{array}$ $\begin{array}{ll}0.059 & 0.0753\end{array}$ $\begin{array}{ll}0.063 & 0.0767\end{array}$ $0.065 \quad 0.0776$ $\begin{array}{ll}0.072 \quad 0.0763 \\ 0.068 & 0.0783\end{array}$ $\begin{array}{ll}0.072 & 0.0763 \\ 0.068 & 0.0783\end{array}$ $\begin{array}{ll}0.071 & 0.0767\end{array}$ $\begin{array}{ll}0.071 & 0.0767\end{array}$ $0.066 \quad 0.0886$ $\begin{array}{lll}0.066 & 0.0886\end{array}$ $0.170 \quad 0.0762$ $\begin{array}{ll}0.063 & 0.0741\end{array}$ $\begin{array}{ll}0.082 & 0.0753\end{array}$ $\begin{array}{ll}0.070 & 0.0752\end{array}$ $\begin{array}{ll}0.072 \quad 0.0763 \\ 0.063 & 0.0759\end{array}$ $\begin{array}{lll}0.063 & 0.0759\end{array}$ $\begin{array}{ll}0.0006 & 0.2141\end{array}$ $0.0004 \quad 0.1976$ $0.0015 \quad 0.2241$ $0.0014 \quad 0.2128$ $\begin{array}{lll}0.0006 & 0.1747\end{array}$ $0.0011 \quad 0.2078$ $0.0011 \quad 0.1910$ $0.0018 \quad 0.1658$ $0.0015 \quad 0.1778$ $0.0015 \quad 0.1990$ $0.0018 \quad 0.1849$ $\begin{array}{lll}0.0004 & 0.1825 \\ 0.0018 & 0.1858\end{array}$ $0.0018 \quad 0.1858$

$0.0014 \quad 0.2073$ $0.0009 \quad 0.1999$ $0.0009 \quad 0.1973$ $0.0007 \quad 0.2012$ $0.0006 \quad 0.1982$ $0.0012 \quad 0.2269$ $0.0017 \quad 0.1851$ $0.0014 \quad 0.2252$ $0.0016 \quad 0.1947$ $0.0015 \quad 0.2196$ $0.0020 \quad 0.1850$ $0.0010 \quad 0.2137$ $0.0011 \quad 0.2184$ $0.0009 \quad 0.2226$

$0.0007 \quad 0.1807$ $0.0004 \quad 0.1816$ $0.0003 \quad 0.1770$ $0.0006 \quad 0.1830$ $0.0007 \quad 0.1782$ $0.0009 \quad 0.1825$ $\begin{array}{ll}0.0008 & 0.1828 \\ 0.0008 & 0.1761\end{array}$ $0.0008 \quad 0.1761$ $0.0007 \quad 0.181$ $0.0007 \quad 0.1806$ $0.0005 \quad 0.1905$ $0.0008 \quad 0.1782$ $0.0007 \quad 0.1764$ $0.0005 \quad 0.1791$ $0.0008 \quad 0.1881$ $0.0009 \quad 0.1889$ $\begin{array}{ll}0.0008 \quad 0.1788 \\ 0.0007 & 0.1908\end{array}$ $0.0007 \quad 0.1908$
$0.0025 \quad 2.455$ $0.0021 \quad 2.170$ $0.0038 \quad 2.592$ $0.0035 \quad 2.445$ 0.0030 $0.0025 \quad 2.474$ 0.00292398 $0.0031 \quad 1.828$ $0.0035 \quad 2.232$ $0.0035 \quad 2.232$ 0.00351 .839

$0.0038 \quad 2.200$ $0.0026 \quad 2.146$ $0.0028 \quad 2.13$ $0.0026 \quad 2.166$ $0.0022 \quad 2.200$ $\begin{array}{ll}0.0035 & 2.517\end{array}$ $0.0037 \quad 1.909$ $0.0022 \quad 1.972$ 0.00432 .732 $0.0041 \quad 2.016$ $0.0042 \quad 2.470$ $0.0046 \quad 1.857$ 0.00312 .376 $0.0034 \quad 2.453$ $0.0031 \quad 2.499$

$0.0022 \quad 1.870$ $0.0022 \quad 1.903$ $0.0019 \quad 1.841$ $0.0021 \quad 1.924$ $0.0021 \quad 1.834$ $0.0024 \quad 1.942$ $0.0023 \quad 1.991$ $0.0022 \quad 1.810$ $0.0021 \quad 1.911$ $0.0025 \quad 2.007$ $0.0023 \quad 1.854$ $0.0020 \quad 1.824$ $0.0029-1.934$ $0.0029 \quad 1.934$ 0.00251 .933 $0.0023 \quad 1.99$
$0.040 \quad 0.0832$ $\begin{array}{ll}0.026 & 0.0796 \\ 0.063 & 0.0839\end{array}$ $\begin{array}{ll}0.057 \quad 0.0833 \\ 0.050 & 0.0744\end{array}$ $0.038 \quad 0.0827$ $\begin{array}{lll}0.059 & 0.0837\end{array}$ $\begin{array}{lll}0.071 \quad 0.0801 & 0.0837\end{array}$ $0.054 \quad 0.0800$ $\begin{array}{ll}0.095 & 0.0804 \\ 0.024 & 0.0763\end{array}$ $\begin{array}{ll}0.024 & 0.0763 \\ 0.061 & 0.0718\end{array}$

$0.082 \quad 0.0770$ $\begin{array}{ll}0.041 & 0.0779\end{array}$ $\begin{array}{ll}0.056 \quad 0.0783 \\ 0.040 & 0.0780\end{array}$ $\begin{array}{lll}0.040 & 0.0780\end{array}$ $\begin{array}{lll}0.140 & 0.0748\end{array}$ $\begin{array}{lll}0.030 & 0.0772\end{array}$ 0.1190 .0880 $0.123 \quad 0.075$ $\begin{array}{ll}0.119 & 0.0816 \\ 0.138 & 0.0728\end{array}$ $0.057 \quad 0.0806$
0.067 $0.067 \quad 0.0815$ $\begin{array}{ll}0.050 & 0.0814\end{array}$

$0.035 \quad 0.0751$ $\begin{array}{ll}0.025 & 0.0760 \\ 0.021 & 0.0754\end{array}$ $\begin{array}{lll}0.021 & 0.0754 \\ 0.028 & 0.0762\end{array}$ $0.038 \quad 0.0746$ $\begin{array}{ll}0.036 & 0.0772\end{array}$ $\begin{array}{ll}0.033 & 0.0790\end{array}$ $\begin{array}{ll}0.039 & 0.0745 \\ 0.028 & 0.0765\end{array}$ $\begin{array}{ll}0.028 & 0.0765\end{array}$ $0.033 \quad 0.0770$ $0.058 \quad 0.0764$ $\begin{array}{ll}0.058 & 0.0755 \\ 0.059 & 0.0758\end{array}$ $\begin{array}{ll}0.059 & 0.0758\end{array}$ $0.025 \quad 0.0739$ $\begin{array}{ll}0.040 \quad 0.0746 \\ 0.036 & 0.0746\end{array}$ $\begin{array}{ll}0.036 & 0.0742 \\ 0.033 & 0.0769\end{array}$ $0.033 \quad 0.076$ $\begin{array}{ll}0.030 & 0.0757\end{array}$ $\begin{array}{lll}0.0009 & 0.715 & 1250\end{array}$ $\begin{array}{lll}0.0004 & 0.900 & 1163\end{array}$ $\begin{array}{lll}0.0015 & 0.698 & 1304\end{array}$ $\begin{array}{llll}0.0014 & 0.706 & 1244\end{array}$ $\begin{array}{lll}0.0016 & 0.608 & 1038\end{array}$ $\begin{array}{lll}0.0008 & 0.752 & 1266\end{array}$ $\begin{array}{lll}0.0017 & 0.575 & 1217\end{array}$ $\begin{array}{llll}0.0024 & 0.434 & 1127\end{array}$ $\begin{array}{lll}0.0018 & 0.643 \quad 989\end{array}$ $\begin{array}{lll}0.0027 & 0.437 & 1055\end{array}$ $\begin{array}{llll}0.0027 & 0.437 & 1055\end{array}$ $\begin{array}{llll}0.0034 & 0.403 & 1094\end{array}$ $\begin{array}{lll}0.0034 & 0.403 & 1094 \\ 0.0005 & 0.875 & 108\end{array}$ $\begin{array}{lll}0.0020 & 0.565 & 1098\end{array}$

$\begin{array}{lll}0.0025 & 0.488 & 1214\end{array}$ $\begin{array}{lll}0.0011 & 0.693 & 1175\end{array}$ $\begin{array}{lll}0.0017 & 0.534 & 116\end{array}$ $\begin{array}{llll}0.0010 & 0.691 \quad 1182\end{array}$ $\begin{array}{lll}0.0006 & 0.827 & 1165\end{array}$ $\begin{array}{llll}0.0019 & 0.541 \quad 1318\end{array}$ $\begin{array}{llll}0.0053 & 0.269 & 1095\end{array}$ $\begin{array}{lll}0.0007 & 0.780 & 1095\end{array}$ $\begin{array}{lll}0.0028 & 0.773 & 1309\end{array}$ $\begin{array}{llll}0.0036 & 0.741 & 114\end{array}$ $\begin{array}{llll}0.0029 & 0.750 & 1280\end{array}$ $\begin{array}{lll}0.0043 & 0.722 \quad 1094\end{array}$ $\begin{array}{lll}0.0015 & 0.610 & 1249\end{array}$ $\begin{array}{lll}0.0018 & 0.579 & 1273\end{array}$ $\begin{array}{lll}0.0012 & 0.683 & 1296\end{array}$

$\begin{array}{lll}0.0011 & 0.655 \quad 107\end{array}$ $\begin{array}{lll}0.0004 & 0.908 & 1076\end{array}$ $\begin{array}{lll}0.0003 & 0.933 & 1051\end{array}$ $\begin{array}{llll}0.0007 & 0.797 & 1084\end{array}$ $\begin{array}{lll}13 & 0.569 & 1057 \\ 10 & 0.704 & 1081\end{array}$ $\begin{array}{lll}0.0010 & 0.704 & 1081 \\ 0.0009 & 0.739 & 1082\end{array}$ $0.0013 \quad 0.591 \quad 1046$ $\begin{array}{llll}0.0007 \quad 0.800 & 1073\end{array}$ $\begin{array}{llll}0.0020 & 0.452 & 1124\end{array}$ $\begin{array}{llll}0.0011 & 0.659 & 1057\end{array}$ $0.0008 \quad 0.940 \quad 1047$ $\begin{array}{llll}0.0008 & 0.940 & 1047\end{array}$ $\begin{array}{llll}0.0010 & 0.744 & 1111\end{array}$ $\begin{array}{lll}0.0010 & 0.710 & 1116\end{array}$ . $\begin{array}{lll}0.0007 & 0.794 & 1126\end{array}$

$13 \quad 1273$

$22 \quad 1290$

$18 \quad 1052$

$13 \quad 1262$

$\begin{array}{lll}16 \quad 1286 & 1262\end{array}$

$15 \quad 1200$

$17 \quad 1196$

$16 \quad 1133$

$19 \quad 1230$

$19 \quad 1206$

$\begin{array}{ll}11 & 1104\end{array}$

21981

$20 \quad 1120$

$\begin{array}{ll}14 & 1143\end{array}$

$15 \quad 1155$

$\begin{array}{ll}14 & 1148\end{array}$

$\begin{array}{ll}19 & 1208\end{array}$

$20 \quad 1064$

$\begin{array}{ll}20 & 1064 \\ 12 & 1127\end{array}$

$\begin{array}{ll}12 & 1127 \\ 22 & 1383\end{array}$

$\begin{array}{ll}22 & 1070\end{array}$

$\begin{array}{ll}22 & 1235\end{array}$ 


$\begin{array}{lllll}20.2 & 288 & 118 & 0.41 & 45.9 \\ 21.1 & 68 & 80 & 1.17 & 11.3 \\ 21.2 & 80 & 55 & 0.69 & 12.5 \\ 22.1 & 60 & 52 & 0.86 & 9.4 \\ 23.1 & 138 & 177 & 1.29 & 21.0\end{array}$

Error in Temora reference zircon calibration was $0.36 \%$ and $0.61 \%$ for the analytical sessions.

NB due to a multiplier malfunction analyses of grains $10-13$ were not considered meaningful

(c) Summary of SHRIMP U-Pb zircon results for sample MAZ 12020.

$\begin{array}{llllllllll}1.1 & 63 & 42 & 0.67 & 10.0 & - & <0.01 & 5.401 & 0.093 & 0.0781 \\ 2.1 & 77 & 65 & 0.84 & 12.3 & - & <0.01 & 5.369 & 0.066 & 0.0769 \\ 2.2 & 124 & 156 & 1.25 & 19.5 & 0.000032 & 0.05 & 5.489 & 0.063 & 0.0770 \\ 3.1 & 72 & 43 & 0.60 & 11.6 & 0.000035 & 0.06 & 5.331 & 0.066 & 0.0779 \\ 3.2 & 127 & 154 & 1.22 & 19.4 & 0.000031 & 0.05 & 5.631 & 0.064 & 0.0763 \\ 4.1 & 141 & 45 & 0.32 & 22.9 & - & <0.01 & 5.286 & 0.060 & 0.0752 \\ 5.1 & 77 & 45 & 0.58 & 12.3 & - & <0.01 & 5.364 & 0.077 & 0.0757 \\ 6.1 & 94 & 55 & 0.59 & 15.2 & 0.000016 & 0.03 & 5.318 & 0.065 & 0.0764 \\ 7.1 & 102 & 80 & 0.79 & 16.1 & - & <0.01 & 5.424 & 0.064 & 0.0763 \\ 8.1 & 98 & 29 & 0.30 & 14.8 & - & <0.01 & 5.691 & 0.069 & 0.0764 \\ 9.1 & 106 & 54 & 0.51 & 17.0 & 0.000071 & 0.12 & 5.360 & 0.062 & 0.0764 \\ 10.1 & 90 & 61 & 0.68 & 14.3 & 0.000017 & 0.03 & 5.430 & 0.065 & 0.0755 \\ 11.1 & 159 & 53 & 0.33 & 25.3 & 0.000050 & 0.08 & 5.403 & 0.067 & 0.0765 \\ 12.1 & 119 & 57 & 0.48 & 18.8 & - & <0.01 & 5.443 & 0.063 & 0.0758 \\ 13.1 & 63 & 41 & 0.65 & 10.0 & 0.000332 & 0.56 & 5.365 & 0.080 & 0.0799 \\ 14.1 & 40 & 31 & 0.76 & 6.3 & 0.000116 & 0.20 & 5.469 & 0.076 & 0.0749 \\ 15.1 & 157 & 35 & 0.22 & 24.8 & 0.000013 & 0.02 & 5.447 & 0.061 & 0.0754 \\ 16.1 & 75 & 24 & 0.32 & 11.6 & 0.000047 & 0.08 & 5.548 & 0.068 & 0.0743 \\ 17.1 & 116 & 62 & 0.54 & 18.6 & 0.000026 & 0.04 & 5.375 & 0.062 & 0.0760 \\ 18.1 & 116 & 39 & 0.33 & 18.6 & - & <0.01 & 5.370 & 0.062 & 0.0757 \\ 19.1 & 82 & 56 & 0.68 & 12.8 & 0.000039 & 0.07 & 5.519 & 0.067 & 0.0752\end{array}$

Error in Temora reference zircon calibration was $0.36 \%$ for the analytical session.

$\begin{array}{llllllll}\text { (d) Summary of SHRIMP } & \text { U-Pb zircon results } & \text { for sample SPP2067. } & \\ 1.1 & 539 & 124 & 0.23 & 93 & 0.000039 & 0.07 & 4.983 \\ 2.1 & 517 & 123 & 0.24 & 89 & 0.000024 & 0.04 & 4.976 \\ 3.1 & 324 & 71 & 0.22 & 55 & 0.000042 & 0.07 & 5.019 \\ 4.1 & 261 & 57 & 0.22 & 46 & 0.000108 & 0.18 & 4.851 \\ 5.1 & 642 & 168 & 0.26 & 113 & 0.000004 & 0.01 & 4.864 \\ 6.1 & 306 & 69 & 0.23 & 54 & 0.000066 & 0.11 & 4.899 \\ 7.1 & 405 & 91 & 0.22 & 71 & - & <0.01 & 4.869 \\ 8.1 & 159 & 26 & 0.17 & 28 & 0.000118 & 0.20 & 4.958 \\ 9.1 & 550 & 121 & 0.22 & 97 & 0.000082 & 0.14 & 4.848 \\ 10.1 & 448 & 112 & 0.25 & 79 & 0.000075 & 0.13 & 4.857\end{array}$

Error in AS3 reference zircon calibration was $0.37 \%$ for the analytical session

\begin{tabular}{llllllll}
\multicolumn{8}{l}{ (e) Summary of SHRIMP $U$-Pb zircon results for samples SPP 6076} \\
1.1 & 578 & 126 & 0.22 & 82.6 & 0.000021 & 0.04 & 6.013 \\
2.1 & 1038 & 192 & 0.18 & 98.7 & 0.000370 & 0.62 & 9.029 \\
3.1 & 536 & 106 & 0.20 & 79.4 & 0.000087 & 0.15 & 5.804 \\
4.1 & 404 & 71 & 0.18 & 49.8 & 0.000099 & 0.17 & 6.964 \\
5.1 & 1077 & 47 & 0.04 & 136.2 & 0.000009 & 0.02 & 6.796 \\
6.1 & 791 & 103 & 0.13 & 82.7 & 0.000462 & 0.79 & 8.218 \\
7.1 & 738 & 52 & 0.07 & 68.1 & 0.000482 & 0.82 & 9.318 \\
8.1 & 596 & 126 & 0.21 & 68.8 & 0.000095 & 0.16 & 7.440 \\
9.1 & 787 & 195 & 0.25 & 113.6 & 0.000053 & 0.09 & 5.949 \\
10.1 & 515 & 95 & 0.18 & 79.3 & 0.000059 & 0.10 & 5.580 \\
11.1 & 745 & 132 & 0.18 & 116.3 & - & $<0.01$ & 5.501
\end{tabular}

$0.053 \quad 0.0814$ $0.052 \quad 0.0815$ $0.055 \quad 0.0808$ $0.054 \quad 0.0810$ $0.051 \quad 0.0803$ $0.054 \quad 0.0812$ $0.053 \quad 0.0802$ $\begin{array}{ll}0.059 & 0.0812\end{array}$ $\begin{array}{ll}0.052 & 0.0797\end{array}$

$0.0009 \quad 0.1853$ $0.0008 \quad 0.1863$ 0.00070 .1821 $0.0010 \quad 0.1875$ $\begin{array}{lll}0.0006 & 0.1775\end{array}$ $0.0006 \quad 0.1892$ $0.0008 \quad 0.1866$ $0.0007 \quad 0.1880$ $0.0007 \quad 0.1846$ $0.0007 \quad 0.1758$ $0.0006 \quad 0.1863$ $0.0007 \quad 0.1841$ $0.0005 \quad 0.1849$ $0.0006 \quad 0.1838$ $0.0006 \quad 0.1838$ 0.00090 .1853 $0.012 \quad 0.1831$ $0.0008 \quad 0.1801$ $0.0008 \quad 0.1801$ $0.0006 \quad 0.1860$ $\begin{array}{ll}0.00008 & 0.1811\end{array}$

$0.0032 \quad 2.006$ $0.0023 \quad 1.975$ $0.0021 \quad 1.923$ $0.0023 \quad 2.000$ 0.00201 .856 0.00211 .963 $0.0027 \quad 1.964$ 0.00231 .973 0.00221 .970 $0.0021 \quad 1.857$ 0.00221 .938 0.00221 .910 $0.0023 \quad 1.932$ $0.0021 \quad 1.935$ $0.0028 \quad 1.920$ $0.0029 \quad 1.917$ $0.0021 \quad 1.903$ 0.00221 .827 0.00221 .827 0.00221 .961 $0.0022 \quad 1.864$

$0.0004 \quad 0.2006$ $0.0005 \quad 0.1991$ $0.0005 \quad 0.2058$ $0.0003 \quad 0.2056$ $0.0005 \quad 0.2039$ $0.0005 \quad 0.2054$ $0.0007 \quad 0.2013$

$\begin{array}{lll}0.0004 & 0.2060\end{array}$

$0.0004 \quad 0.2056$

$0.0021 \quad 2.235$ $\begin{array}{ll}0.0021 \quad 2.247 \\ 0.0022 & 2.202\end{array}$ $0.0022 \quad 2.202$ $0.0023 \quad 2.254$ $0.0022 \quad 2.275$ $0.0022 \quad 2.257$ $0.0022 \quad 2.275$ $\begin{array}{ll}0.0024 & 2.207 \\ 0.0022 & 2.254\end{array}$ $0.0022 \quad 2.254$ $0.0022 \quad 2.230$

$\begin{array}{ll}0.065 \quad 0.0759 \\ 0.093 & 0.089\end{array}$ $\begin{array}{lll}0.093 & 0.0819\end{array}$ $\begin{array}{lll}0.065 & 0.0775\end{array}$ $0.080 \quad 0.0773$ $0.069 \quad 0.0719$ $\begin{array}{ll}0.108 & 0.0802\end{array}$ $\begin{array}{ll}0.095 \quad 0.0822 \\ 0.096 & 0.0768\end{array}$ $0.096 \quad 0.0768$ $0.099 \quad 0.0769$ $0.099 \quad 0.0766$ $\begin{array}{ll}0.056 & 0.0767\end{array}$ $\begin{array}{llll}0.0004 & 0.1663 & 0.0018 & 1.733\end{array}$ $0.0004 \quad 0.1101$ $\begin{array}{ll}0.0004 & 0.1720 \\ 0.0005 & 0.1433\end{array}$ $\begin{array}{ll}0.0005 & 0.1433\end{array}$ $0.0003 \quad 0.147$ $0.0004 \quad 0.1207$ $\begin{array}{lll}0.0006 & 0.1064\end{array}$ $0.0005 \quad 0.1342$
0.003 $0.0003 \quad 0.1680$ $\begin{array}{ll}0.0011 & 0.1790\end{array}$ $0.0003 \quad 0.1818$ $0.0011 \quad 1.163$ 0.00191 .808 $0.0016 \quad 1.500$ 0.00151 .45 $0.0016 \quad 1.225$ $0.0011 \quad 1.106$ $0.0017 \quad 1.395$ $0.0028 \quad 1.765$ $0.0032 \quad 1.871$ $0.0018 \quad 1.925$
$0.042 \quad 0.0785$ $\begin{array}{ll}0.032 \quad 0.0769 \\ 0.028 & 0.0766\end{array}$ $\begin{array}{ll}0.028 \quad 0.0766 \\ 0.038 & 0.0774\end{array}$ $0.038 \quad 0.0774$
0.078 $0.028 \quad 0.0758$ $\begin{array}{ll}0.027 & 0.0752\end{array}$ $\begin{array}{ll}0.036 & 0.0763\end{array}$ $\begin{array}{ll}0.031 & 0.0761\end{array}$ $0.031 \quad 0.0774$ $\begin{array}{ll}0.028 & 0.0766\end{array}$ $\begin{array}{ll}0.030 & 0.0754\end{array}$ $\begin{array}{lll}0.030 & 0.0752\end{array}$ $0.029 \quad 0.0758$ $0.028 \quad 0.0763$ $\begin{array}{ll}0.050 & 0.0752\end{array}$ $0.099 \quad 0.0759$ $0.027 \quad 0.0752$ $0.034 \quad 0.0736$ $\begin{array}{lll}0.029 & 0.0756 \\ 0.030 & 0.0763\end{array}$ $\begin{array}{lll}0.034 & 0.0747\end{array}$

$\begin{array}{ll}0.028 & 0.0808\end{array}$ $0.027 \quad 0.081$ $\begin{array}{ll}0.031 & 0.0802\end{array}$ $\begin{array}{ll}0.035 & 0.0794\end{array}$ $\begin{array}{lll}0.026 & 0.0803\end{array}$ $0.029 \quad 0.083$ 0.0290 .0803 $0.044 \quad 0.0795$ $0.030 \quad 0.0786$

$0.021 \quad 0.0756$ $0.019 \quad 0.0766$ $\begin{array}{ll}0.025 \quad 0.0762 \\ 0.021 & 0.0759\end{array}$ $0.016 \quad 0.0718$ \begin{tabular}{ll}
0.029 & 0.0736 \\
\hline
\end{tabular} $\begin{array}{ll}0.022 \quad 0.0753 \\ 0.022 & 0.0754\end{array}$ $0.022 \quad 0.0754$ $0.031 \quad 0.0762$ $0.044 \quad 0.0758$ $0.021 \quad 0.0768$ $\begin{array}{llll}0.0009 & 0.826 & 1096\end{array}$ $\begin{array}{llll}0.0008 & 0.756 & 1101\end{array}$ $\begin{array}{lll}0.0007 & 0.779 & 1078\end{array}$ $\begin{array}{llll}0.0001 & 0.779 & 1078\end{array}$ $\begin{array}{lll}0.0007 & 0.763 \quad 1053\end{array}$ $\begin{array}{lll}0.0006 & 0.822 & 111\end{array}$ $\begin{array}{lll}0.0009 & 0.785 & 1103\end{array}$ $\begin{array}{lll}0.0007 & 0.789 & 1110\end{array}$ $\begin{array}{lll}0.0008 & 0.739 & 1092\end{array}$ $\begin{array}{lll}0.0007 & 0.791 & 1044\end{array}$ $\begin{array}{lll}0.0008 & 0.757 & 1102\end{array}$ $\begin{array}{llll}0.0007 & 0.773 & 1089\end{array}$ $\begin{array}{lll}0.0006 & 0.836 & 1094\end{array}$ $\begin{array}{llll}0.0007 & 0.794 & 1088\end{array}$ $\begin{array}{llll}0.0016 & 0.576 & 1096\end{array}$ $\begin{array}{lll}0.0031 & 0.766 & 1084\end{array}$ $\begin{array}{lll}0.0007 & 0.787 \quad 1086\end{array}$ $\begin{array}{llll}0.0010 & 0.666 \quad 1068\end{array}$ $\begin{array}{llll}0.0007 & 0.771 & 1099\end{array}$ $\begin{array}{lll}0.0007 \quad 0.767 & 1102\end{array}$ $\begin{array}{llll}0.0010 & 0.675 \quad 1073\end{array}$

$17 \quad 1161$ $11 \quad 1110$

131130

111090

121075

$15 \quad 1104$

121098

12113

12111

$12 \quad 1080$

$\begin{array}{ll}12 & 1075\end{array}$

$\begin{array}{ll}12 & 1089 \\ 12 & 1104\end{array}$

$\begin{array}{ll}12 & 1104 \\ 15 & 1073\end{array}$

$\begin{array}{ll}15 & 1073 \\ 16 & 1093\end{array}$

$\begin{array}{ll}16 & 1093 \\ 11 & 1074\end{array}$

$\begin{array}{ll}11 & 1074 \\ 1 & -1030\end{array}$

$\begin{array}{ll}12 & 1030 \\ 12 & 1085\end{array}$

(2)

$12 \quad 1059$

$\begin{array}{lll}0.0005 & 0.856 & 1178\end{array}$ $\begin{array}{lll}0.0005 & 0.866 & 1180\end{array}$ $\begin{array}{llll}0.0007 & 0.768 & 1170\end{array}$ $\begin{array}{lll}0.0008 & 0.726 & 1206\end{array}$ $0.0003 \quad 0.926 \quad 1205$ $0.0008 \quad 0.754 \quad 1196$ $\begin{array}{llll}0.0006 & 0.841 \quad 1204\end{array}$ $\begin{array}{lll}0.0013 & 0.600 & 1182\end{array}$ $\begin{array}{lll}0.0006 & 0.813 & 1205\end{array}$

$11 \quad 1217$

$\begin{array}{ll}11 & 1224\end{array}$

$12 \quad 1202$

12118

$12 \quad 1203$

$\begin{array}{ll}12 & 1204 \\ 12 & 1205\end{array}$

$\begin{array}{ll}12 & 1205 \\ 13 & 1185\end{array}$

$\begin{array}{ll}13 & 1185 \\ 12 & 1182\end{array}$

$\begin{array}{ll}12 & 1162\end{array}$

$\begin{array}{ll}23 & 6\end{array}$

$21 \quad 2$

$28 \quad 2$

$\begin{array}{ll}19 & 3 \\ 16 & -4\end{array}$

$\begin{array}{ll}16 & -4 \\ 23 & 0\end{array}$

$\begin{array}{ll}19 & -1\end{array}$

$\begin{array}{ll}21 & 3 \\ 19 & 6\end{array}$

$20-2$

$\begin{array}{ll}20 & -1\end{array}$

$\begin{array}{ll}16 & 0\end{array}$

$\begin{array}{ll}18 & 1 \\ 43 & -2\end{array}$

$\begin{array}{ll}43 & -2 \\ 81 & 1\end{array}$

$\begin{array}{ll}81 & 1 \\ 18 & -1\end{array}$

$\begin{array}{ll}18 & -1 \\ 28 & -4\end{array}$

$19-1$

$\begin{array}{ll}19 & 0 \\ 27 & -1\end{array}$

$\begin{array}{lll}0.0004 & 0.900 & 991\end{array}$ $\begin{array}{llll}0.0010 & 0.628 & 673\end{array}$ $\begin{array}{lll}0.0006 & 0.800 & 1023\end{array}$ $\begin{array}{lll}0.0006 & 0.805 & 864\end{array}$ $\begin{array}{llll}0.0003 & 0.920 & 885\end{array}$ $\begin{array}{lll}0.0014 & 0.570 & 735\end{array}$ $\begin{array}{lll}0.0013 & 0.513 & 652\end{array}$ $0.0006 \quad 0.832 \quad 812$ $\begin{array}{llll}0.0004 & 0.949 & 1001\end{array}$ $\begin{array}{lll}0.0012 & 0.759 & 1062\end{array}$ $\begin{array}{llll}0.0003 & 0.926 \quad 1077\end{array}$

$\begin{array}{llll}10 & 1084 & 10 & 9 \\ 7 & 1111 & 26 & 65 \\ 11 & 1101 & 17 & 8 \\ 9 & 1092 & 17 & 26 \\ 8 & 980 & 9 & 11 \\ 9 & 1031 & 39 & 40 \\ 6 & 1078 & 35 & 65 \\ 10 & 1079 & 17 & 33 \\ 16 & 1100 & 11 & 10 \\ 17 & 1090 & 31 & 3 \\ 10 & 1116 & 8 & 4\end{array}$

(continued on next page) 


\begin{tabular}{|c|c|c|c|c|c|c|c|c|c|c|c|c|c|c|c|c|c|c|c|c|c|c|}
\hline \multirow{2}{*}{$\begin{array}{l}\text { Grain. } \\
\text { spot }\end{array}$} & \multirow{2}{*}{$\begin{array}{l}\mathrm{U} \\
(\mathrm{ppm})\end{array}$} & \multirow{2}{*}{$\begin{array}{l}\text { Th } \\
(\mathrm{ppm})\end{array}$} & \multirow[t]{2}{*}{$\mathrm{Th} / \mathrm{U}$} & \multirow{2}{*}{$\begin{array}{l}{ }^{206} \mathrm{~Pb}^{*} \\
(\mathrm{ppm})\end{array}$} & \multirow[t]{2}{*}{${ }^{204} \mathrm{~Pb} /{ }^{206} \mathrm{~Pb}$} & \multirow[t]{2}{*}{$f_{206} \%$} & \multicolumn{4}{|c|}{ Total Ratios } & \multicolumn{6}{|c|}{ Radiogenic Ratios } & \multirow[t]{2}{*}{$\rho$} & \multicolumn{5}{|l|}{ Age (Ma) } \\
\hline & & & & & & & ${ }^{238} \mathrm{U} /{ }^{206} \mathrm{~Pb}$ & \pm & ${ }^{207} \mathrm{~Pb} /{ }^{206} \mathrm{~Pb}$ & \pm & ${ }^{206} \mathrm{~Pb} /{ }^{238} \mathrm{U}$ & \pm & ${ }^{207} \mathrm{~Pb} /{ }^{235} \mathrm{U}$ & \pm & ${ }^{207} \mathrm{~Pb} /{ }^{206} \mathrm{~Pb}$ & \pm & & ${ }^{206} \mathrm{~Pb} /{ }^{238} \mathrm{U}$ & \pm & ${ }^{207} \mathrm{~Pb} /{ }^{206} \mathrm{~Pb}$ & \pm & $\begin{array}{l}\% \\
\text { Disc }\end{array}$ \\
\hline 12.1 & 380 & 101 & 0.27 & 55.2 & - & $<0.01$ & 5.913 & 0.065 & 0.0773 & 0.0005 & 0.1691 & 0.0019 & 1.802 & 0.022 & 0.0773 & 0.0005 & 0.882 & 1007 & 10 & 1128 & 12 & 12 \\
\hline 13.1 & 617 & 127 & 0.21 & 76.6 & 0.000398 & 0.67 & 6.923 & 0.071 & 0.0810 & 0.0007 & 0.1435 & 0.0015 & 1.490 & 0.029 & 0.0753 & 0.0013 & 0.520 & 864 & 8 & 1078 & 34 & 25 \\
\hline 14.1 & 616 & 130 & 0.21 & 92.7 & 0.000029 & 0.05 & 5.711 & 0.059 & 0.0771 & 0.0003 & 0.1750 & 0.0018 & 1.851 & 0.021 & 0.0767 & 0.0004 & 0.902 & 1040 & 10 & 1113 & 10 & 7 \\
\hline 16.1 & 849 & 205 & 0.24 & 102.5 & 0.000937 & 1.59 & 7.116 & 0.082 & 0.0872 & 0.0072 & 0.1383 & 0.0020 & 1.409 & 0.199 & 0.0739 & 0.0104 & 0.102 & 835 & 11 & 1038 & 283 & 24 \\
\hline 17.1 & 538 & 38 & 0.07 & 77.7 & 0.000025 & 0.04 & 5.943 & 0.061 & 0.0753 & 0.0006 & 0.1682 & 0.0017 & 1.738 & 0.023 & 0.0750 & 0.0006 & 0.782 & 1002 & 10 & 1068 & 16 & 7 \\
\hline 18.1 & 367 & 143 & 0.39 & 60.9 & - & $<0.01$ & 5.174 & 0.061 & 0.0767 & 0.0005 & 0.1933 & 0.0023 & 2.052 & 0.027 & 0.0770 & 0.0005 & 0.882 & 1139 & 12 & 1121 & 13 & -2 \\
\hline 19.1 & 805 & 40 & 0.05 & 110.9 & 0.000005 & 0.01 & 6.235 & 0.067 & 0.0741 & 0.0003 & 0.1604 & 0.0017 & 1.637 & 0.019 & 0.0741 & 0.0003 & 0.928 & 959 & 10 & 1043 & 9 & 9 \\
\hline 20.1 & 215 & 66 & 0.31 & 23.3 & 0.000064 & 0.11 & 7.939 & 0.089 & 0.0774 & 0.0006 & 0.1258 & 0.0014 & 1.327 & 0.020 & 0.0765 & 0.0008 & 0.730 & 764 & 8 & 1108 & 21 & 45 \\
\hline 21.1 & 1282 & 587 & 0.46 & 173.3 & 0.000020 & 0.03 & 6.354 & 0.108 & 0.0749 & 0.0011 & 0.1573 & 0.0027 & 1.619 & 0.036 & 0.0746 & 0.0011 & 0.752 & 942 & 15 & 1058 & 30 & 12 \\
\hline 22.1 & 425 & 78 & 0.18 & 58.8 & 0.000073 & 0.12 & 6.208 & 0.065 & 0.0772 & 0.0005 & 0.1609 & 0.0017 & 1.691 & 0.022 & 0.0762 & 0.0006 & 0.808 & 962 & 9 & 1101 & 15 & 14 \\
\hline 23.1 & 895 & 97 & 0.11 & 137.2 & 0.000006 & 0.01 & 5.602 & 0.063 & 0.0743 & 0.0003 & 0.1785 & 0.0020 & 1.827 & 0.022 & 0.0742 & 0.0003 & 0.929 & 1059 & 11 & 1048 & 9 & -1 \\
\hline $\begin{array}{l}\text { Error in } \\
\text { For area }\end{array}$ & $\begin{array}{l}\mathrm{C} 1 \text { refere } \\
\text { younger }\end{array}$ & $\begin{array}{l}\text { ence zircc } \\
\text { than } \sim 8\end{array}$ & $\begin{array}{l}\text { A calibr } \\
0 \text { Ma co }\end{array}$ & $\begin{array}{l}\text { ation was } \\
\text { prrection }\end{array}$ & $\begin{array}{l}95 \% \text { for the ar } \\
\text { common } \mathrm{Pb}\end{array}$ & $\begin{array}{l}\text { nalytical } \\
\text { made us }\end{array}$ & $\begin{array}{l}1 \text { session. } \\
\text { sing the mea }\end{array}$ & asured ${ }^{2}$ & ${ }^{238} \mathrm{U} /{ }^{206} \mathrm{~Pb}$ an & $\mathrm{Ad}^{207} \mathrm{~Pb} /$ & ${ }^{206} \mathrm{~Pb}$ ratios & & & & & & & & & & & \\
\hline (J) & . & 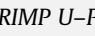 & . & (1 & ample SPP-414 & & & & & & & & & & & & & & & & & \\
\hline 1.1 & 1187 & 33 & 0.028 & 171 & - & $<0.01$ & 5.976 & 0.062 & 0.0738 & 0.0003 & 0.1673 & 0.0017 & 1.705 & 0.019 & 0.0739 & 0.0003 & 0.934 & 997 & 10 & 1038 & 8 & 4 \\
\hline 2.1 & 962 & 22 & 0.022 & 128 & - & $<0.01$ & 6.449 & 0.068 & 0.0737 & 0.0003 & 0.1551 & 0.0016 & 1.577 & 0.018 & 0.0738 & 0.0003 & 0.913 & 929 & 9 & 1035 & 9 & 10 \\
\hline 3.1 & 624 & 26 & 0.042 & 86 & 0.000135 & 0.23 & 6.237 & 0.069 & 0.0749 & 0.0005 & 0.1600 & 0.0018 & 1.609 & 0.023 & 0.0730 & 0.0007 & 0.764 & 957 & 10 & 1013 & 19 & 6 \\
\hline 4.1 & 933 & 20 & 0.022 & 134 & 0.000036 & 0.06 & 5.983 & 0.064 & 0.0735 & 0.0004 & 0.1670 & 0.0018 & 1.681 & 0.020 & 0.0730 & 0.0004 & 0.894 & 996 & 10 & 1014 & 11 & 2 \\
\hline 5.1 & 863 & 121 & 0.140 & 75 & 0.001415 & 2.51 & 9.912 & 0.107 & 0.0901 & 0.0038 & 0.0984 & 0.0012 & 0.947 & 0.076 & 0.0698 & 0.0056 & 0.148 & 605 & 7 & 923 & 164 & 35 \\
\hline 6.1 & 942 & 15 & 0.016 & 127 & 0.000292 & 0.50 & 6.392 & 0.068 & 0.0778 & 0.0004 & 0.1557 & 0.0017 & 1.580 & 0.022 & 0.0736 & 0.0007 & 0.768 & 933 & 9 & 1031 & 18 & 10 \\
\hline 7.1 & 1133 & 4 & 0.004 & 168 & 0.000001 & $<0.01$ & 5.806 & 0.061 & 0.0737 & 0.0003 & 0.1722 & 0.0018 & 1.749 & 0.020 & 0.0737 & 0.0003 & 0.929 & 1024 & 10 & 1032 & 8 & 1 \\
\hline 8.1 & 1196 & 213 & 0.178 & 141 & 0.000084 & 0.15 & 7.292 & 0.076 & 0.0714 & 0.0003 & 0.1369 & 0.0014 & 1.326 & 0.016 & 0.0702 & 0.0004 & 0.877 & 827 & 8 & 934 & 12 & 11 \\
\hline 9.1 & 930 & 59 & 0.063 & 131 & 0.000046 & 0.08 & 6.087 & 0.064 & 0.0736 & 0.0003 & 0.1642 & 0.0017 & 1.651 & 0.020 & 0.0730 & 0.0004 & 0.879 & 980 & 10 & 1013 & 12 & 3 \\
\hline 10.1 & 925 & 62 & 0.067 & 134 & 0.000058 & 0.10 & 5.913 & 0.062 & 0.0737 & 0.0005 & 0.1690 & 0.0018 & 1.697 & 0.023 & 0.0729 & 0.0006 & 0.781 & 1006 & 10 & 1010 & 17 & 0 \\
\hline 11.1 & 793 & 41 & 0.052 & 109 & 0.000078 & 0.13 & 6.277 & 0.074 & 0.0746 & 0.0004 & 0.1591 & 0.0019 & 1.612 & 0.022 & 0.0735 & 0.0005 & 0.876 & 952 & 10 & 1028 & 13 & 7 \\
\hline 12.1 & 1438 & 145 & 0.101 & 159 & 0.000405 & 0.71 & 7.778 & 0.084 & 0.0783 & 0.0005 & 0.1277 & 0.0014 & 1.276 & 0.021 & 0.0725 & 0.0009 & 0.659 & 775 & 8 & 1000 & 25 & 23 \\
\hline 13.1 & 1115 & 130 & 0.116 & 96 & 0.000480 & 0.85 & 9.968 & 0.105 & 0.0785 & 0.0004 & 0.0995 & 0.0010 & 0.982 & 0.015 & 0.0716 & 0.0008 & 0.670 & 611 & 6 & 974 & 24 & 37 \\
\hline 14.1 & 1112 & 721 & 0.648 & 126 & 0.002386 & 4.17 & 7.569 & 0.080 & 0.1079 & 0.0019 & 0.1266 & 0.0015 & 1.289 & 0.065 & 0.0739 & 0.0036 & 0.230 & 768 & 8 & 1038 & 98 & 26 \\
\hline 15.1 & 1041 & 7 & 0.007 & 160 & 0.000009 & 0.01 & 5.578 & 0.068 & 0.0739 & 0.0006 & 0.1792 & 0.0022 & 1.822 & 0.026 & 0.0737 & 0.0006 & 0.837 & 1063 & 12 & 1034 & 16 & -3 \\
\hline 16.1 & 696 & 66 & 0.095 & 97 & 0.000106 & 0.18 & 6.161 & 0.066 & 0.0738 & 0.0004 & 0.1620 & 0.0017 & 1.615 & 0.021 & 0.0723 & 0.0005 & 0.829 & 968 & 10 & 994 & 15 & 3 \\
\hline 16.2 & 497 & 28 & 0.056 & 71 & 0.000065 & 0.11 & 6.033 & 0.066 & 0.0751 & 0.0005 & 0.1656 & 0.0018 & 1.694 & 0.023 & 0.0742 & 0.0006 & 0.820 & 988 & 10 & 1047 & 15 & 6 \\
\hline 17.1 & 1439 & 155 & 0.108 & 166 & 0.000176 & 0.31 & 7.435 & 0.077 & 0.0729 & 0.0003 & 0.1341 & 0.0014 & 1.302 & 0.017 & 0.0704 & 0.0006 & 0.790 & 811 & 8 & 940 & 17 & 14 \\
\hline 18.1 & 1001 & 54 & 0.054 & 128 & 0.000064 & 0.11 & 6.743 & 0.071 & 0.0732 & 0.0004 & 0.1481 & 0.0016 & 1.476 & 0.018 & 0.0722 & 0.0005 & 0.852 & 891 & 9 & 993 & 13 & 10 \\
\hline & & & & & & & & & & & & & & & & & & & & & & \\
\hline 195 & P II & & & & & & & & & & & & & & & & & & & & & \\
\hline $1.1 \mathrm{lw}$ & 175 & 88 & 0.50 & 30 & 0.000019 & 0.03 & 5.063 & 0.060 & 0.0781 & 0.0007 & 0.1975 & 0.0023 & 2.118 & 0.032 & 0.0778 & 0.0007 & 0.784 & 1162 & 13 & 1142 & 19 & -2 \\
\hline $2.1 \mathrm{lw}$ & 119 & 101 & 0.85 & 8 & 0.000898 & 1.67 & 12.159 & 0.162 & 0.0610 & 0.0011 & 0.0810 & 0.0013 & 0.543 & 0.051 & 0.0486 & 0.0040 & 0.743 & 502 & 8 & & & \\
\hline $3.1 \mathrm{lr}$ & 388 & 95 & 0.25 & 42 & 0.000281 & 0.48 & 7.877 & 0.089 & 0.0753 & 0.0007 & 0.1263 & 0.0014 & 1.241 & 0.032 & 0.0713 & 0.0016 & 0.447 & 767 & 8 & 965 & 47 & 21 \\
\hline $4.1 \mathrm{lw}$ & 241 & 109 & 0.45 & 17 & - & $<0.01$ & 12.497 & 0.148 & 0.0590 & 0.0008 & 0.0801 & 0.0010 & 0.666 & 0.015 & 0.0602 & 0.0012 & 0.516 & 497 & 6 & 612 & 43 & 19 \\
\hline $5.1 \mathrm{lr}$ & 114 & 32 & 0.28 & 18 & 0.000399 & 0.68 & 5.589 & 0.071 & 0.0768 & 0.0009 & 0.1780 & 0.0024 & 1.774 & 0.051 & 0.0723 & 0.0015 & 0.753 & 1056 & 13 & 994 & 42 & -6 \\
\hline $6.1 \mathrm{lr}$ & 730 & 107 & 0.15 & 120 & 0.000097 & 0.16 & 5.250 & 0.056 & 0.0765 & 0.0004 & 0.1906 & 0.0021 & 2.017 & 0.030 & 0.0768 & 0.0005 & 0.905 & 1124 & 11 & 1115 & 13 & -1 \\
\hline $7.1 \mathrm{lr}$ & 215 & 30 & 0.14 & 33 & 0.000215 & 0.37 & 5.583 & 0.064 & 0.0758 & 0.0006 & 0.1786 & 0.0021 & 1.808 & 0.033 & 0.0734 & 0.0008 & 0.818 & 1059 & 11 & 1025 & 22 & -3 \\
\hline $8.1 \mathrm{lr}$ & 285 & 76 & 0.27 & 44 & 0.000170 & 0.29 & 5.543 & 0.062 & 0.0781 & 0.0006 & 0.1799 & 0.0020 & 1.878 & 0.036 & 0.0757 & 0.0012 & 0.585 & 1066 & 11 & 1087 & 31 & 2 \\
\hline $9.1 \mathrm{dc}$ & 1388 & 184 & 0.13 & 223 & 0.000006 & 0.01 & 5.349 & 0.055 & 0.0760 & 0.0002 & 0.1869 & 0.0019 & 1.957 & 0.021 & 0.0759 & 0.0002 & 0.960 & 1105 & 10 & 1093 & 6 & -1 \\
\hline $10.1 \mathrm{dc}$ & 4938 & 614 & 0.12 & 918 & 0.000074 & 0.12 & 4.623 & 0.047 & 0.0772 & 0.0001 & 0.2161 & 0.0022 & 2.268 & 0.024 & 0.0761 & 0.0002 & 0.978 & 1261 & 12 & 1099 & 4 & -15 \\
\hline $11.1 \mathrm{lw}$ & 462 & 143 & 0.31 & 79 & 0.000025 & 0.04 & 5.018 & 0.054 & 0.0779 & 0.0004 & 0.1992 & 0.0021 & 2.130 & 0.027 & 0.0775 & 0.0005 & 0.852 & 1171 & 11 & 1135 & 13 & -3 \\
\hline $2008 \mathrm{SH}$ & $I M P R G$ & & & & & & & & & & & & & & & & & & & & & \\
\hline $6.2 \mathrm{lc}$ & 287 & 126 & 0.44 & 49 & 0.000011 & 0.02 & 4.999 & 0.057 & 0.0813 & 0.0005 & 0.2000 & 0.0023 & 2.238 & 0.029 & 0.0812 & 0.0005 & 0.869 & 1175 & 12 & 1226 & 13 & 4 \\
\hline $6.3 \mathrm{lr}$ & 943 & 162 & 0.17 & 158 & 0.000034 & 0.06 & 5.119 & 0.067 & 0.0761 & 0.0003 & 0.1954 & 0.0026 & 2.048 & 0.038 & 0.0760 & 0.0006 & 0.926 & 1150 & 14 & 1096 & 16 & -5 \\
\hline $7.2 \mathrm{lr}$ & 419 & 85 & 0.20 & 63 & 0.000047 & 0.08 & 5.712 & 0.063 & 0.0755 & 0.0004 & 0.1749 & 0.0019 & 1.805 & 0.023 & 0.0749 & 0.0005 & 0.872 & 1039 & 11 & 1065 & 13 & 2 \\
\hline $7.3 \mathrm{lc}$ & 120 & 40 & 0.33 & 21 & 0.000044 & 0.07 & 4.984 & 0.066 & 0.0830 & 0.0008 & 0.2005 & 0.0026 & 2.278 & 0.041 & 0.0824 & 0.0010 & 0.732 & 1178 & 14 & 1255 & 24 & 6 \\
\hline & 182 & 5 & 030 & 20 & & ת 0 & & & 00760 & & & בכחת ח & 1850 & & & & 0770 & & 17 & & 23 & \\
\hline
\end{tabular}


tT-Oth-4

$m \stackrel{\sim}{\sim} \stackrel{\infty}{\sim} \stackrel{N}{\sim} \sigma=$

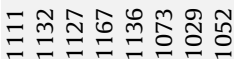

$\forall m \underline{m} m=$

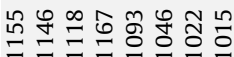

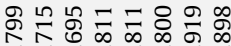

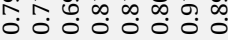

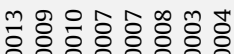

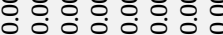

ㅊำํำ

o.

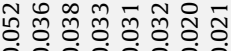

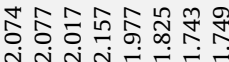

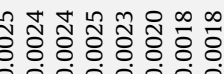

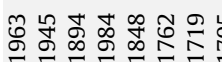

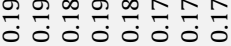

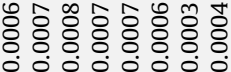

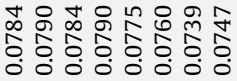

๘ี

० 00000

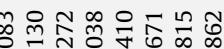

구

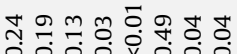

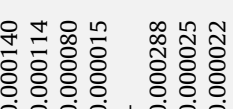

సั

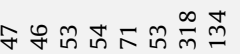

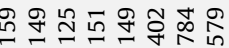

$\underline{3} \underline{3} \underline{3} \underline{3}=0$

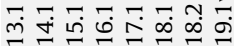



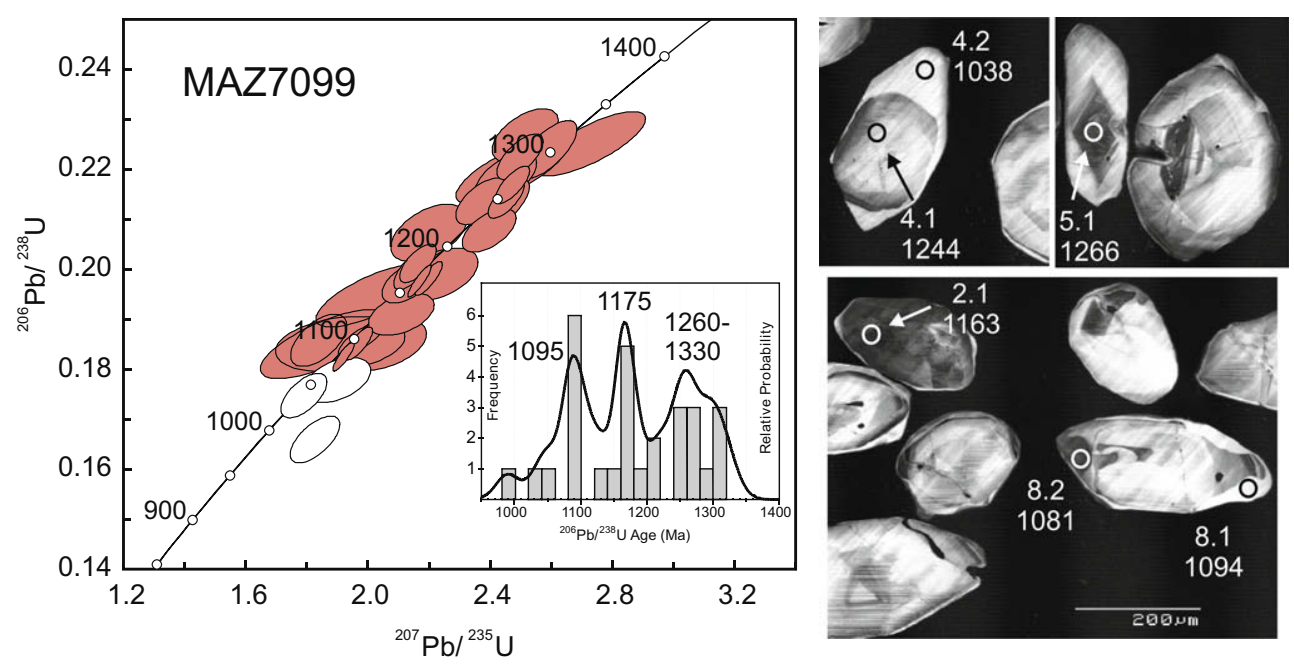

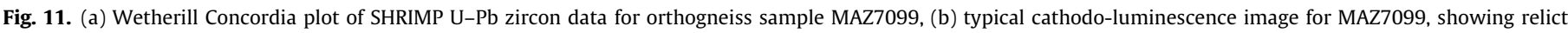

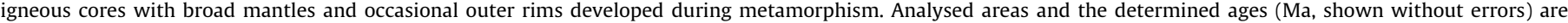
identified (Table 4). See text for detailed interpretation.

The zircons from this sample are equant to elongate grains, subhedral to euhedral, most with sub-round terminations, or are fragments of such grains. They are notably smaller than grains in the other samples, being generally $\leqslant 100 \mu \mathrm{m}$ in length. The CL images show a range of internal structures. Most have oscillatory zoning, or length-parallel zones consistent with an igneous paragenesis. However, many have a two-part internal structure with either bright CL zoned centres and darker CL zoned outer or rim components. Some grains have an outermost rim or zone with dark, more homogeneous CL. The areas analysed have relatively high U contents, ranging from ca. 215 to ca. $1280 \mathrm{ppm}$, mostly more than $500 \mathrm{ppm} \mathrm{U}$. Th/U ratios are generally in the range ca. $0.1-0.45$ with several grains having ratios $\leqslant 0.07$; grains 5 and 19 being the lowest at 0.04 and 0.05 , respectively. On a standard Wetherill Concordia plot (Fig. 12d) the data range from concordant within uncertainty to ca. $65 \%$ discordant. Note that the analysis of grain 16 is very imprecise and is not considered in this discussion, nor plotted on Fig. 12d. Nineteen of the remaining 22 analyses define a simple $\mathrm{Pb}$ loss discordia line with an upper intercept at $1110 \pm 10 \mathrm{Ma}$ (MSWD 1.4). The lower Concordia intercept for this line at ca. $77 \mathrm{Ma}$, albeit with a very large uncertainty, could reflect Andean reactivation but is not relevant to the Grenville-age history. Three analyses plot to the younger-age side of the dominant discordia regression line and it is notable that two of these have the lowest Th/U ratios (grains 5 and 19). The third analysis (grain 23) also has a low $\mathrm{Th} / \mathrm{U}$ ratio of 0.11 , but there are no distinguishing morphological or CL features to indicate that these three analysed areas are otherwise different from those within uncertainty of the dominant $\mathrm{Pb}$ loss discordia line. The three analyses scatter about a line that has an upper intercept at about $1055 \mathrm{Ma}$ (MSWD 6.7, not shown on Fig. 12d). The upper Concordia intercept for zoned igneous zircon at $1110 \pm 10 \mathrm{Ma}$ is considered to be the best estimate of the protolith age, with indications that a younger metamorphic overprint has given rise to non-zero age radiogenic $\mathrm{Pb}$ loss.

SPP414a, Sierra de Pie de Palo $\left(31^{\circ} 18^{\prime} 40.0^{\prime \prime}, 69^{\circ} 55^{\prime} 45.0^{\prime \prime}\right)$. This (Fig. 8) from the imbricate thrust domain belongs to an orthogneiss suite that yielded a $\mathrm{Rb}-\mathrm{Sr}$ whole-rock isochron age of $1021 \pm 12 \mathrm{Ma}$ (Pankhurst and Rapela, 1998); it was analysed on SHRIMP as a further control and comparison with the other more recent samples. The main mineralogy is Pl-Qtz-Kfs-Bt-Anf-Grt1-Grt2; accessories are All, Ep, Ap, and $\mathrm{Zrn}$ and the metamorphic assemblage is Grt2-Bt-Anf. The granular texture is dominated relict crystals of plagioclase and granular quartz. Two different types of garnet are recognized: Grt1 (igneous?) which is larger, subhedral and devoid of inclusions, and Grt2 (metamorphic), smaller, poikilitic and euhedral, and associated with Bt and Anf.

The zircons from this sample are dominantly metamict elongate, subhedral grains. They are mostly are dark and clouded with alteration products, but a few grains are clear, or there are clear areas on the tips to otherwise metamict zircon. The CL images reinforce the metamict nature of most of the zircon; the few clear areas have weak zoning, but most are dark and featureless. $U$ contents are high, ranging from ca. 500 to ca. 1440 ppm, mostly greater than $900 \mathrm{ppm} \mathrm{U}$. Th contents vary widely, with the Th/U ratio ranging from ca. 0.004 to ca. 0.65 ; most are $<0.07$ suggesting that the zircon areas analysed are of a metamorphic origin. As may be expected from the analyses of such metamict and U-rich zircons, most of the analyses are discordant (up to ca. 35\%), although 13 are only $10 \%$ discordant or less. A regression line fitted to all 19 areas analysed has excess scatter $(M S W D=3.2)$ with an upper Concordia intercept at $1027 \pm 17 \mathrm{Ma}$ (Fig. 12e). The lower Concordia intercept of $166 \pm 94 \mathrm{Ma}$ is of doubtful geological significance. A weighted mean of ${ }^{207} \mathrm{~Pb} /{ }^{206} \mathrm{~Pb}$ ages for the least discordant group gives $1025 \pm 10 \mathrm{Ma}$ (MSWD =1.7). This is in agreement with the published $\mathrm{Rb}-\mathrm{Sr}$ age, but is significantly younger than any other Grenville-age event so far determined from the Western Sierras Pampeanas (see Fig. 13). On the basis of the CL images and Th/U ratios it is likely that this reflects a period of metamorphic zircon growth, although it must be noted that the metamict nature of the grains indicates that even the more concordant of analyses may have lost radiogenic $\mathrm{Pb}$ during a late Grenville-age fluid movement or thermal episode.

ULLU2100, Precordillera (37²8' 34.01"; 68 $\left.48^{\circ} 9^{\prime} 27.07^{\prime \prime}\right)$. This sample is of a metamorphic xenolith within a Miocene diorite intruded through the Precordillera sequence and cropping out at Ullún, as described by Abruzzi et al. (1993) and Kay et al. (1996). The sample is a calc-alkaline - metagabbro (Fig. 8c), and geochemically it corresponds to the mafic amphibolite group described by those authors. Its main mineralogy consists of $\mathrm{Pl}-\mathrm{Hbl}-\mathrm{Cum} / \mathrm{Tr}-$ Bt-Qtz, with accessories Ep, Zrn, Op, and quite common alteration to Chl, Ilm, and sericite. The fabric is formed by a coarse-grained equigranular aggregate of $\mathrm{Hb}, \mathrm{Pl}$ and clusters of fibrous $\mathrm{Cum} / \mathrm{Tr}$ clino-amphiboles, probably replacing primary $\mathrm{Fe}-\mathrm{Mg}$ pyroxene.

The zircons from this sample are quite unusual. Under transmitted light there are two distinct types: a relatively clear 

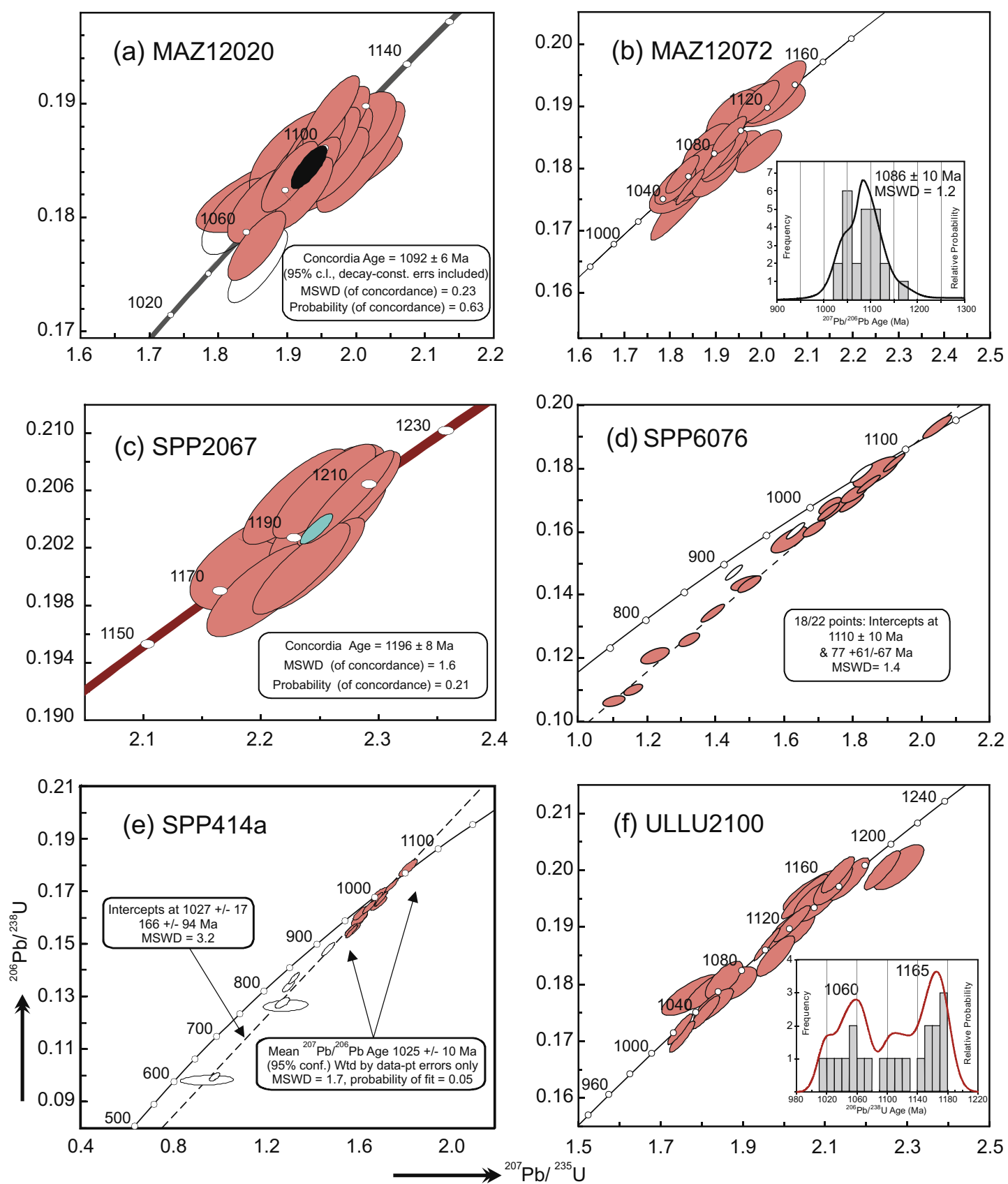

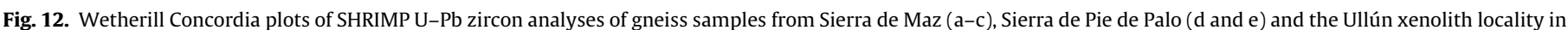
the Precordillera (f). See text for detailed descriptions and interpretation.

anhedral component that forms discrete, larger elongate to subequant grains, and a component that is inclusion-rich, in places metamict. The inclusion-rich zircon occurs as elongate to subequant, smaller grains that have round to sub-round grain shapes. In places, the clear component can be seen to rim the other. The $\mathrm{CL}$ images highlight these markedly different zircon types. The clear zircon is seen as very bright luminescent rims and whole grains. The inclusion-rich component has mottled and very irregular darker CL characteristics, often rimmed by the bright $\mathrm{CL}$ component. In some large grains (grains 6 and 7) both rims and cores have bright CL.

The analyses of these complex zircon grains concentrated on the bright $\mathrm{CL}$ areas, the dark mottled $\mathrm{CL}$ areas being considered metamict and so unlikely to yield consistent or meaningful $\mathrm{U}-\mathrm{Pb}$ data. Nevertheless, for completeness, some dark mottled CL areas were analysed (see Table 4). Overall there appears to be little cor- relation between age $\left({ }^{207} \mathrm{~Pb} /{ }^{206} \mathrm{~Pb}\right.$ or $\left.{ }^{206} \mathrm{~Pb} /{ }^{238} \mathrm{U}\right)$ and spot location, though in general terms the whole clear grains tend to give older ages, greater than $1130 \mathrm{Ma}$. On the other hand, two clear grains (2 and 4) give Cambro-Ordovician dates that undoubtedly reflect the late history of the Precordillera terrane. There is also little correlation between grain type or CL characteristics and U content; some light CL rims have $>500 \mathrm{ppm} \mathrm{U}$, others $<200 \mathrm{ppm} \mathrm{U}$; overall the $\mathrm{Th} / \mathrm{U}$ ratios are in the range ca. $0.2-0.45$, which is normal for igneous zircon. The enlarged Wetherill Concordia plot shown as Fig. $12 \mathrm{f}$ excludes the two Palaeozoic grains ( 2 and 4 ), the normally discordant analysis of grain 3 and the reversely discordant, dark CL core to grain 10 (metamict). The data on this plot form two distinct groupings that are concordant to within analytical uncertainty and distinguished in the relative probability plot of ${ }^{206} \mathrm{~Pb} /{ }^{238} \mathrm{U}$ ages (shown inset). One group is concordant at about $1165 \mathrm{Ma}$ and 


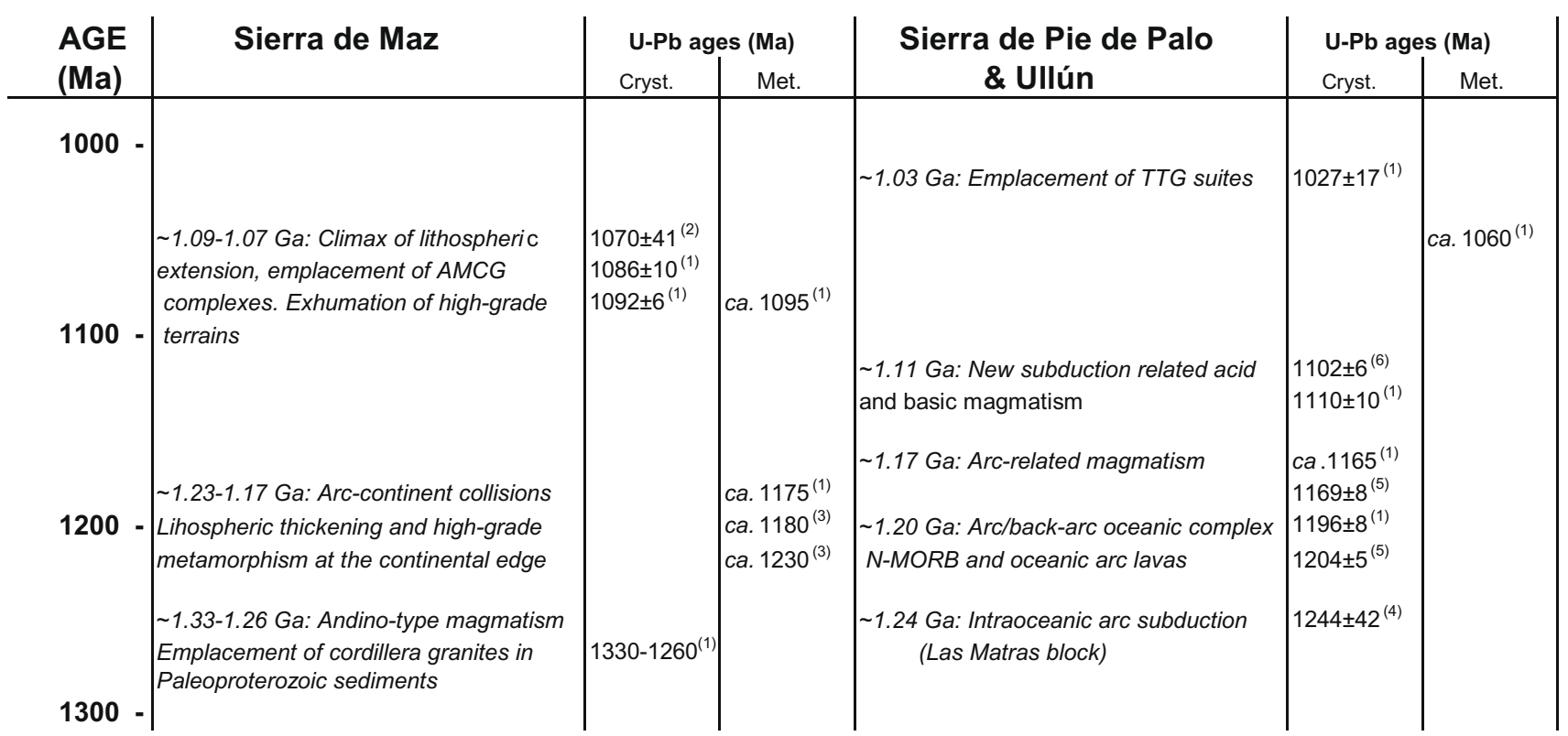

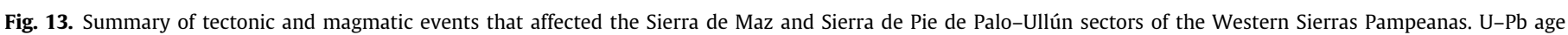
references: (1) this study, (2) Casquet et al. (2004), (3) Casquet et al. (2006), (4) Sato et al. (2004), (5) Vujovich et al. (2004), and (6) Kay et al. (1996).

the other at about $1060 \mathrm{Ma}$, with a further subgroup of two discordant analyses (Fig. 12f) that have similar ${ }^{206} \mathrm{~Pb} /{ }^{238} \mathrm{U}$ ratios to the ca. $1165 \mathrm{Ma}$ group, but with older ${ }^{207} \mathrm{~Pb} /{ }^{206} \mathrm{~Pb}$ ratios and ages (the inner light CL cores, analyses 6.2 and 7.3). Whilst it is recognised that these are complex zircons that exhibit atypical CL characteristics and structure and ensuing $\mathrm{U}-\mathrm{Pb}$ systematics, we suggest that the older grouping at ca. 1165 Ma provides an estimate for zircon crystallisation in the gabbroic protolith of this metamorphic xenolith, whereas the ca. $1060 \mathrm{Ma}$ group reflects a period of zircon growth during metamorphism.

\section{Discussion: the geodynamic history of the Western Sierras Pampeanas}

A summary of the main lithotectonic elements recognized in the Sierra de Maz and Sierra de Pie de Palo-Ullún sectors of the WSP is shown in Fig. 13, based on U-Pb SHRIMP dating of igneous and metamorphic events obtained in representative samples of the different magmatic series identified in each sector (Figs. 4-12). Due to the very complex structural imbrication and the several overprinted events recorded in the WSP, the scenario depicted in Fig. 13 must be tested in future detailed studies of the WSP.

The oldest igneous event registered in the WSP is represented by suites of dioritic to granitic subalkaline orthogneisses of Sierra de Maz (ca. 1330-1260 Ma, Figs. 4a and 11). These rocks are characteristic of Andean-style I-type granites intruded in a continental crust (see Section 4.1.1). Metasedimentary rocks in the SE sector of the Maz Domain that are likely the country rocks of this series contain 1.7-1.9 Ga detrital zircons, indicating a Late Paleoproterozoic source for the metasedimentary envelope, and early Paleoproterozoic Nd model ages (Casquet et al., 2006, 2008). There is no evidence to constrain the length of time taken by this event. Taking into account that the granitic suite is relatively abundant and that zircon metamorphic overgrowths in the country rocks range from 1180 to $1230 \mathrm{Ma}$ (Casquet et al., 2006), the duration of this first stage of continental-edge magmatism has been tentatively extended to approximately $1230 \mathrm{Ma}$ (Fig. 13).

No similar continental-edge environment has been identified in Sierra de Pie de Palo where, in contrast, the oldest rocks (gabbro
SPP2067, $1196 \pm 8$ Ma, Fig. 12c; Vujovich et al. 2004 reported an age of $1204 \pm 8 \mathrm{Ma}$ in similar rocks) show clear geochemical evidence of having formed in an oceanic arc/back-arc environment (Vujovich and Kay, 1998; Vujovich et al., 2004) (see Fig. 9a and b). Fig. 13 shows the arc/back-arc oceanic system of Pie Palo evolving separately from the Andino-type margin inferred for Sierra de Maz. The different composition between the juvenile oceanic Sierra de Pie de Palo and the continental, mature environment of Sierra de Maz, is well depicted by their contrasting Nd isotopic signatures (Fig. 6). The juvenile tonalite-trondhjemites of the Las Matras block, further south (Fig. 1), suggest an oceanic arc at ca. $1244 \mathrm{Ma}$ (Sato et al., 2004), either as an earlier stage of the Pie de Palo system, or as an independent arc (Fig. 13).

An important amphibolite facies metamorphic event affected the metadiorite MAZ7099, and produced an age peak ca. 1175 Ma defined by concordant spots in well-developed metamorphic zircon rims (Fig. 11). Metamorphic rims defining a coeval peak at ca. $1180 \mathrm{Ma}$ and an older one at ca. $1230 \mathrm{Ma}$ were reported in garnet schists and basic granulites within a different sliver of the Maz Central Domain (Casquet et al., 2006). Granulite facies $\left(780{ }^{\circ} \mathrm{C}, 780 \mathrm{MPa}\right.$ ) and a crustal depth of $\mathrm{ca} .29 \mathrm{~km}$ were calculated for this Grenville-age metamorphism (Casquet et al., 2006), which is here ascribed to an arc-continent collision in the Sierra de Maz sector (Fig. 13). After the collision, the early continental-edge of Sierra de Maz became a deformed foreland environment and the site of intraplate continental magmatism. The inferred suture between the continent and the accreted oceanic arc is not exposed, but was probably a weakly sheared zone, reactivated by major transcurrent faults during the Cambrian? Docking of the WSP against the Río de la Plata Craton (Rapela et al., 2007; Casquet et al., 2008c).

No equivalent overprinted coeval metamorphic rims have been so far found in the analysed rocks of the Sierra de Pie de Palo-Ullún sector and the Las Matras block (Sato et al., 2000), suggesting that these arc and arc/back-arc systems were not directly involved in the Maz arc-continent collision. What is so far found at ca. $1170 \mathrm{Ma}$ in this sector is the evidence of a new convergent event given by (i) $1169 \pm 8 \mathrm{Ma}$ tonalite/granodiorite sills and dykes intruded into the basic arc/back-arc sequence of Sierra de Pie de Palo (Vujovich et al., 2004) and (ii) basic arc magmatism in the Precord- 
illera (ULLU2100, ca. 1165 Ma, Fig. 12f, 13). Oceanic arc subduction was operating at the time an arc-continent collision occurred in the Maz sector, suggesting either they were two independent arc systems or that the Pie de Palo-Ullún sector is a southern (present coordinates) remnant branch of the same arc system, not affected by the collision. The Ullún sector has been considered as an oceanic arc/back-arc environment near a continental margin (Kay et al. 1996).

A new episode of convergence in the Pie de Palo-Ullún sector is represented by $1110 \pm 10$ Ma calc-alkaline orthogneisses (SPP6076, Figs. 8b, 12d, 13) and mafic amphibolite xenoliths (1102 $\pm 6 \mathrm{Ma}$, Kay et al., 1996). These ages overlap within errors, and suggest that the Pie de Palo outcrops and the Ullún xenoliths belonged to the same basement at that time. Compared with the previous (ca. $1200 \mathrm{Ma}$ ) subduction event of Pie de Palo, the calc-alkaline gneisses show a relatively high $\mathrm{La} / \mathrm{Yb}$ ratio (Fig. 10), suggesting a plagioclase-poor mineral residue formed in a thicker crust. This event probably affected large sectors of the WSP, taken into account that a suite of $1108 \pm 13$ Ma calc-alkaline orthogneisses with similar geochemical characteristics (Fig. 10a and b), has been also reported in Sierra de Umango (Varela et al. 2003) (Fig. 10a, b). Altogether the widespread ca. 1100 episode suggests that the Pie de Palo-Ullún sector was accreted or adjacent to the continent at that age.

A final Mesoproterozoic subduction event is represented by the $1027 \pm 17$ Ma Mogote-Corralito tonalite-trondhjemite gneisses (Figs. 12e, 13), which show low $[\mathrm{La} / \mathrm{Yb}]_{\mathrm{N}}$ between 2.4 and 2.9 (Fig. 9c), indicating a source located above the garnet stability field and therefore within thin crust. An important tectonic event must have taken place between these two younger convergent episodes, to explain their contrasting geochemical signature. Such a significant magmatic event is represented in Sierra de Maz by the 1070-1090 intraplate intrusion of AMCG complexes (Fig. 13). The age of the $1070 \pm 41$ Ma massif anorthosite of Sierra de Maz (Casquet et al., 2004) overlaps within errors both the $1092 \pm 6 \mathrm{Ma}$ meta-mangerite (MAZ12020, Fig. 12a) and the ca. 1088 Ma metagranite (MAZ12072, Fig. 12b) reported here, and interpreted collectively as an AMCG complex. The large uncertainty in the anorthosite age does not allow to confirmation they are truly coeval, but if this interpretation is correct the age of the whole complex would be ca. $1090 \mathrm{Ma}$, i.e., the age of the more precisely dated meta-mangerite. Intrusion of these slightly contaminated mantle-derived magmas during a widespread extensional episode would have produced an important thermal overprint in surrounding rocks. The $1330-1260$ Ma meta-granitic suite located close to the AMCG complex (see Fig. 2) shows a peak age of zircon mantle overgrowths at $1095 \mathrm{Ma}$ (Fig. 11). The mafic granulite xenoliths of the Precordillera show zircon metamorphic overgrowths at $\mathrm{ca}$. $1060 \mathrm{Ma}$ (Fig. 12f), and the $1102 \pm 6$ Ma mafic amphibolite xenolith contains two zircon fractions with significantly lower $\mathrm{U}$ and $\mathrm{Pb}$ concentration, interpreted as a metamorphic event at $\sim 1083 \mathrm{Ma}$ (Kay et al., 1996). This evidence points to a regional thermal event that we here relate to the ponding of mantle magmas at the base of the crust and the intrusion of AMCG complexes during an extensional episode (Fig. 13). Intramontane basins most probably formed during this episode, and should therefore contain only pre-1060 Ma detrital zircons, as is the case of the Morteritos schists in Sierra de El Gigante (Rapela et al., 2007).

Despite the structurally complex imbrication produced by the Paleozoic and Mesozoic (Andean) orogenies, the inferred major Mesoproterozoic geological events and their timing seem to define a protracted but coherent geodynamic history for the Western Sierras Pampeanas. This started at ca. $1330 \mathrm{Ma}$ and ended at ca. $1030 \mathrm{Ma}$ with convergent events at a continental margin, and included between these limits the formation of oceanic arc/backarc complexes, arc-continent collisions, renewed subduction and an intraplate extensional episode with intrusion of AMCG com- plexes. This is the history of a complex, composite arc system developed facing a long-lived ocean.

Although the issues of provenance of the Western Sierras Pampeanas and their original links with other Grenville-age orogens of the terrane collage are beyond the scope of this work, it is necessary to mention that several of the stages described above have been interpreted as evidence for Laurentian provenance, e.g., the basement of the Precordillera (Kay et al., 1996), the arc/backarc sequence of Sierra de Pie de Palo (Vujovich and Kay, 1998) and the massif-type anorthosites of the Sierra de Maz Central Domain (Casquet et al., 2004), among others. There is no doubt that several of the geodynamic entities identified in the Western Sierras Pampeanas (Fig. 13) have also been described in the Laurentian Grenville belt, such as Andean calc-alkaline magmatic arcs and coeval back-arc deposits, as well as episodes of extension and intrusion of AMCG complexes, the youngest of which was emplaced at ca. 1090-1050 Ma (Rivers, 1997; Corrigan and Hanmer, 1997) and was thus broadly coeval with the Maz AMCG complex (Fig. 13). Nevertheless, as Rodinia reconstruction is still a matter of speculative debate, these comparisons should be taken with caution. For example, an arc-continent collision at ca. $1170 \mathrm{Ma}$ and an important metamorphism bracketed at ca. 1090-1050 Ma have been identified in the Natal-Namaqua belt of southern Africa (Jacobs et al., 2003 and references therein), which in some reconstruction is placed facing the Grenville orogen. Both of these events are conspicuous features now identified in the Western Sierras Pampeanas.

\section{Conclusions}

The study of Mesoproterozoic rocks of the sierras of Maz and Pie de Palo reveals a protracted (300 Ma long) geological history. As these terrains represent contrasting crustal environments that sometimes experienced coeval events, it is possible to reconstruct and interpret their episodic evolution. Sierra de Maz seems to have been part of a continental crust throughout this period, starting as a Paleoproterozoic continental margin during Andean type-subduction at least $1330 \mathrm{Ma}$ ago. This margin became a foreland intraplate site after an arc-continent collision, developing high-grade metamorphism at 1230-1170 Ma. During an extensional event defining the culmination of the Mesoproterozoic history in the Maz region, the intrusion of $\mathrm{ca}$. 1050-1090, mantle-derived, intraplate AMCG complexes produced a strong thermal overprint on previous continental-arc suites. On the other hand, the Mesoproterozoic sequences of the Sierra de Pie de Palo-Ullún sector are dominated by oceanic arc and back-arc rocks, which were products of a fully developed and active arc system ca. $1200 \mathrm{Ma}$ ago. A new subduction event at $\sim 1170$ Ma overprinted the old arc/back-arc, while a $1110 \mathrm{Ma}$ episode seems to have been emplaced into crust that had become more mature. Now located at the continental margin, the juvenile accreted terranes underwent later emplacement of subduction-related plutons at $1027 \mathrm{Ma}$. As in other Grenville-age terrains, the geodynamic history of the Mesoproterozoic WSP is dominated by convergent tectonics, either at continental margins or intra-oceanic arcs, with episodes of arc-continent collisions and emplacement of AMCG complexes during extensional events.

\section{Acknowledgements}

Financial support for this paper was provided by Spanish MEC Grants BTE2001-1486 and CGL2005-02065/BTE, Universidad Complutense Grant PR1/05-13291 and Argentine Grants PIP-CONICET 5719 and FONCYT PICT 2006-1009. R.J.P. acknowledges the support of the NERC Isotope Geosciences Laboratory at BGS. We appreciate constructive reviews by A. Nutman and R. Fuck. 


\section{References}

Abruzzi, J.M., Kay, S.M., Bickford, M.E., 1993. Implications for the nature of the Precordilleran basement from the geochemistry and age of Precambrian xenoliths in Miocene volcanic rocks, San Juan province. In: XII Congreso Geológico Argentino y II Congreso de Exploración de Hidrocarburos, Mendoza, Actas, vol. III, pp. 331-339.

Astini, R., Ramos, V.A., Benedetto, J., Vaccari, N., Cañas, F.L., 1996. La Precordillera: un terreno exótico a Gondwana. In: XIII Congreso Geológico Argentino y III Congreso de Exploración de Hidrocarburos, Actas, vol. 5, pp. 293-324.

Baldo, E., Dahlquist, J., Rapela, C.W., Casquet, C., Pankhurst, R.J., Galindo, C., Fanning, C.M., 2005. Early Ordovician peraluminous magmatism in the Sierra de Pie de Palo, (Western Sierras Pampeanas): geotectonic implications. In: Pankhurst, R.J., Veiga, G.D. (Eds.), International Congress “Gondwana 12", Abstracts Academia Nacional de Ciencias. Argentina, p. 57.

Baldo, E., Casquet, C., Pankhurst, R.J., Galindo, C., Rapela, C.W., Fanning, C.M., Dahlquist, J.A., Murra, J., 2006. Neoproterozoic A-type granitic magmatism in the Western Sierras Pampeanas (Argentina): evidence for Rodinia break-up along a proto-Iapetus rift? Terranova 18, 388-394.

Baldo, D.E.G., Casquet, C., Colombo, F., Pankhurst, R.J., Galindo, C., Rapela, C.W., Dahlquist, J., Fanning, C.M., 2008. Magmatismo anorogénico Neoproterozoico (845 Ma) en las Sierras Pampeanas Occidentales de Maz y Umango. Nueva evidencia del rifting temprano de Rodinia? In: XVII Congreso Geológico Argentino, Tomo I, 181p.

Basei, M., Ramos, V.A., Vujovich, G.I., Poma, S., 1998. El basamento metamórfico de la Cordillera Frontal de Mendoza: nuevos datos geocronológicos e isotópicos. In: $X$ Congreso Latinoamericano de Geología y VI Congreso Nacional de Geología Económica (Buenos Aires), Actas, vol. 2, pp. 412-417.

Black, L.P., Kamo, S.L., Allen, C.M., Aleinikoff, J.N., Davis, D.W., Korsch, R.J., Foudoulis, C., 2003. TEMORA 1: a new zircon standard for Phanerozoic $\mathrm{U}-\mathrm{Pb}$ geochronology. Chemical Geology 200, 155-170.

Caminos, R., 1979. Sierras Pampeanas Noroccidentales. Salta, Tucumán, Catamarca, La Rioja y San Juan. In: Segundo Simposio de Geología, Regional Argentina, Academia Nacional de Ciencias de Córdoba, vol. 1, pp. 225-291.

Casquet, C., Baldo, E., Pankhurst, R.J., Rapela, C.W., Galindo, C., Fanning, C.M., Saavedra, J., 2001. Involvement of the Argentine Precordillera Terrane in the Famatinian mobile belt: Geochronological (U-Pb SHRIMP) and metamorphic evidence from the Sierra de Pie de Palo. Geology 29, 703-706.

Casquet, C., Rapela, C.W., Pankhurst, R.J., Galindo, C., Dahlquist, J., Baldo, E.G., Saavedra, J., González Casado, J.M., Fanning, C.M., 2004. Grenvillian massif-type anorthosites in the Sierras Pampeanas. Journal of the Geological Society, London 162, 9-12.

Casquet, C., Pankhurst, R.J., Rapela, C.W., Fanning, C.M., Galindo, C., Baldo, E., González-Casado, J.M., Dahlquist, J.M., Saavedra, J., 2005. The Maz suspect terrane: a new Proterozoic domain in the Western Sierras Pampeanas. In: Pankhurst, R.J., Veiga, G.D. (Eds.), International Congress "Gondwana 12". Academia Nacional de Ciencias, Argentina, Abstracts, p. 92.

Casquet, C., Pankhurst, R.J., Fanning, C.M., Baldo, E., Galindo, C., Rapela, C., GonzálezCasado, J.M., Dahlquist, J.A., 2006. U-Pb SHRIMP zircon dating of Grenvillian metamorphism in Western Sierras Pampeanas (Argentina): correlation with the Arequipa Antofalla craton and constraints on the extent of the Precordillera Terrane. Gondwana Research 9, 524-529.

Casquet, C., Pankhurst, R.J., Rapela, C.W., Galindo, C., Fanning, C.M., Chiaradia, M., Baldo, E., González-Casado, J.M., Dahlquist, J.A., 2008a. The Mesoproterozoic Maz terrane in the Western Sierras Pampeanas, Argentina, equivalent to the Arequipa-Antofalla block of southern Peru? Implications for West Gondwana margin evolution. Gondwana Research 13, 163-175.

Casquet, C., Pankhurst, R.J., Galindo, C., Rapela, C.W., Fanning, C.M., Baldo, E., Dahlquist, J., González Casado, J.M., Colombo, F., 2008b. A deformed alkaline igneous rock - carbonatite complex from the Western Sierras Pampeanas, Argentina: evidence for late Neoproterozoic opening of the Clymene Ocean? Precambrian Research 165, 205-220.

Casquet, C., Rapela, C.W., Baldo, E., Pankhurst, R.J., Dahlquist, J., González-Casado, J.M., Galindo, C., Fanning, C.M., Saavedra, J., 2008c. Allochthoneity of the Argentine precordillera terrane: an alternative to current paleogeographical models. In: 33th. International Geological Congress, Oslo. CD-ROOM, 1pp.

Cingolani, C.A., Varela, R., 1999. Rb-Sr isotope age of basement rocks of the San Rafael Block, Mendoza, Argentina. In: II South American Symposium on Isotope Geology, Actas, Villa Carlos Paz, Argentina, pp. 23-26.

Corrigan, D., Hanmer, S., 1997. Anorthosites and related terranes in the Grenville orogen: A product of convective thinning of the lithosphere? Geology 25, 6164.

Eby, G.N., 1990. The A-type granites: a review of their occurrence and chemical characteristics and speculations on their petrogenesis. Lithos 26, 115-134.

Emslie, R.F., 1978. Anorthosite massifs, rapakivi granites, and late Proterozoic rifting of North America. Precambrian Research 7, 61-98.

Ewart, A., 1982. The mineralogy and petrology of Tertiary-Recent orogenic volcanic rocks: with special references to the andesite-basalt compositional range. In: Thorpe, R.S. (Ed.), Andesites. New York, Wiley, pp. 25-95.

Finney, S., 2008. The Cambrian to Carboniferous migration of the Cuyania terrane of western Argentina. In: 33th. International Geological Congress, Oslo. CD-ROOM, $1 \mathrm{pp}$

Frost, B.R., Barnes, C.G., Collins, W.J., Arculus, R.J., Ellis, S.J., Frost, C.D., 2001. A geochemical classification for granitic rocks. Journal of Petrology 42, 20332048.
Galindo, C., Casquet, C., Rapela, C., Pankhurst, R.J., Baldo, E., Saavedra, J., 2004. Sr, C and $\mathrm{O}$ isotope geochemistry and stratigraphy of Precambrian and Lower Paleozoic carbonate sequences from the Western Sierras Pampeanas of Argentina: tectonic implications. Precambrian Research 131, 55-71.

Goodge, J.W., Fanning, C.M., Bennett, V.C., 2001. U-Pb evidence of 1.7 Ga crustal tectonism during the Nimrod Orogeny in the Transantarctic Mountains, Antarctica: implications for Proterozoic plate reconstructions. Precambrian Research 112, 261-288.

Hervé, F., Pankhurst, R.J., Fanning, C.M., Calderón, M., Yaxley, G.M., 2007. The South Patagonian batholith: 150 my of granite magmatism on a static plate margin. Lithos 97, 373-394.

Jacobs, J., Bauer, W., Fanning, C.M., 2003. New age constraints for Grenville-age metamorphism in western central Dronning Maud Land (East Antarctica), and implications for the palaeogeography of Kalahari in Rodinia. International Journal of Earth Sciences 92, 301-315.

Kay, S.M., Orrell, S., Abruzzi, J.M., 1996. Zircon and whole-rock Nd-Pb isotopic evidence for a Grenville age and Laurentian origin for the basement of the Precordillera in Argentina. Journal of Geology 104, 637-648.

Kretz, R., 1983. Symbols for rock-forming minerals. American Mineralogist 68, $277-$ 279.

Leat, P.T., Jackson, S.E., Thorpe, R.S., Stillman, C.J., 1986. Geochemistry of bimodal basalt-subalkaline/peralkaline rhyolite provinces within the Southern British Caledonides. Journal of the Geological Society, London 143, 259-273.

Le Maitre, R.W. (Ed.), 1989. A Classification of Igneous Rocks and Glossary of Terms Recommendations of the International Union of Geological Sciences on the Systematics of Igneous Rocks. Blackwell, Oxford, p. 193.

Leveratto, M.A., 1968. Geología de la zona al oeste de Ullún-Zonda, borde oriental de la Precordillera de San Juan, eruptividad subvolcánica y estructura. Revista Asociación Geológica Argentina 23, 129-157.

Lucassen, F., Becchio, R., 2003. Timing of high-grade metamorphism: early Palaeozoic $\mathrm{U}-\mathrm{Pb}$ formation ages of titanite indicate long-standing high-T conditions at the western margin of Gondwana (Argentina, 26-29 ${ }^{\circ} \mathrm{S}$ ). Journal of Metamorphic Geology 21, 649-662.

Ludwig, K.R., 2001. SQUID 1.02, A User's Manual; Berkeley Geochronology Center Special Publication. No. 2, 2455 Ridge Road, Berkeley, CA 94709, USA.

Ludwig, K.R. 2003. User's manual for Isoplot/Ex, Version 3.0, A geochronological toolkit for Microsoft Excel. Berkeley Geochronology Center Special Publication No. 4, 2455 Ridge Road, Berkeley CA 94709, USA.

McDonough, M.R., Ramos, V.A., Isachsen, C.E., Bowring, S.A., Vujovich, G.I., 1993 Edades preliminares de circones del basamento de la Sierra de Pie de Palo Sierras Pampeanas occidentales de San Juán: sus implicancias para el supercontinente proterozoico de Rodinia. In: XII Congreso Geológico Argentino y II Congreso de Exploración de Hidrocarburos, Mendoza, Actas, vol. 3, pp. 340-342.

Middlemost, E.A.K., 1997. Magmas, rocks and planetary development. Longman, Singapore. 299 pp.

Mulcahy, S.R., Roeske, S.M., McClelland, W.C., Nomade, S., Renne, P.R., 2007 Cambrian initiation of the Las Pirquitas thrust of the western Sierras Pampeanas, Argentina: implications for the tectonic evolution of the protoAnean margin of South America. Geology 35, 443-446.

Nakamura, N., 1974. Determination of REE, Ba, Fe, Mg, Na and $\mathrm{K}$ in carbonaceous and ordinary chondrites. Geochimica et Cosmochimica Acta 38, 757-773.

Paces, J.B., Miller, J.D., 1993. Precise U-Pb ages of Duluth complex and related mafic intrusions, northeastern Minnesota: geochronological insights to physical, petrogenetic, paleomagnetic, and tectonomagmatic process associated with the $1.1 \mathrm{Ga}$ Midcontinent Rift System. Journal of Geophysical Research 98, 13.997-14.013.

Pankhurst, R.J., Rapela, C.W., 1998. The proto-Andean margin of Gondwana: an introduction. In: Pankhurst, R.J., Rapela, C.W. (Eds.), The Proto-Andean Margin of Gondwana, vol. 142. Geological Society, London, pp. 1-9 (special publication).

Pearce, J.A., Harris, N.B.W., Tindle, A.G., 1984. Trace element discrimination diagrams for the tectonic interpretation of granitic rocks. Journal of Petrology 25, 956-983.

Porcher, C.C., Fernandes, L.A.D., Vujovich, G.I., Chernicoff, C.J., 2004 Thermobarometry, Sm/Nd ages and geophysical evidence for the location of the suture zone between Cuyania and Pampia terranes. Gondwana Research 7, 1057-1076.

Ramos, V.A., Vujovich, G., Dallmeyer, R.D., 1996. Los klippes y ventanas tectónicas preándicas de la Sierra de Pie de Palo (San Juan): Edad e implicaciones tectónicas. In: XIII Congreso Geológico Argentino y III Congreso de Exploración de Hidrocarburos, Actas, vol. 5, pp. 377-391.

Ramos, V.A., Basei, M., 1997. The basement of Chilenia: an exotic continental terrane to Gondwana during the early Paleozoic. In: Bradshaw, J.D., Weaver, S.D. (Eds.), Terrane dynamics-97. International Conference on Terrane Geology, Christchurch, New Zealand, Conference Abstracts, pp. 140-143.

Rapela, C.W., Pankhurst, R.J., Casquet, C., Fanning, C.M., Galindo, C., Baldo, E., 2005 Datación U-Pb SHRIMP de circones detríticos en para-anfibolitas neoproterozoicas de la secuencia Difunta Correa (Sierras Pampeanas Occidentales, Argentina). Geogaceta 38, 227-230.

Rapela, C.W., Pankhurst, R.J., Casquet, C., Fanning, C.M., Baldo, E.G., GonzálezCasado, J.M., Galindo, C., Dahlquist, J., 2007. The Río de la Plata craton and the assembly of SW Gondwana. Earth Science Reviews 8, 49-82.

Rivers, T., 1997. Lithotectonic elements of the Grenville Province: review and tectonic implications. Precambrian Research 86, 117-154. 
Sambridge, M.S., Compston, W.J., 1994. Mixture modeling of multi-component data sets with application to ion-probe zircon ages. Earth and Planetary Science Letters 128, 373-390.

Sato, A.M., Tickyj, H., Llambías, E.J., Sato, K., 2000. The Las Matras tonalitictrondhjemitic pluton, central Argentina: Grenvillian-age constraints, geochemical characteristics, and regional implications. Journal of South American Earth Sciences 13, 587-610.

Sato, A.M., Tickyj, H., Llambías, Basei, M.A., González, P.D., 2004. The Las Matras Block, central Argentina $\left(37^{\circ} \mathrm{S}-67^{\circ} \mathrm{W}\right)$ : the southernmost Cuyania terrane and its relationship with the Famatinian orogeny. Gondwana Research 7, 10771087.

Sun, S.-S., McDonough, W.F., 1989. Chemical and isotopic systematics of oceanic basalts: implication for mantle compositions and processes. In: Saunders, A.D., Norry, M.J. (Eds.), Magmatism in the Ocean Basins, vol. 42. Geological Society, London, pp. 313-345 (special publication).

Thomas, W.A., Astini, R., 2008. The Ordovician Ocloyic orogenic belt along western Gondwana. In: 33th International Geological Congress, Oslo. CD-ROOM, 1pp.

Varela, R., Dalla Salda, L.H., 1993. Geocronología Rb-Sr de metamorfitas y granitoides del tercio sur de la Sierra de Pie de Palo, San Juan, Argentina. Revista Asociación Geológica Argentina 47, 271-275.

Varela, R., Valencio, S.A., Ramos, A.M., Sato, K., González, P.D., Panarello, H.O., Roverano, D.R., 2001. Isotopic strontium, carbon and oxygen study on
Neorproterozoic marbles from sierra de Umango, Andean Foreland, Argentina. In: III South American Symposium on Isotope Geology, Pucón Chile, Revista Comunicaciones, vol. 52. Santiago, p. 121.

Varela, R., Basei, M., Sato, A., Siga Jr, O., 2003. Proterozoico medio y Paleozoico inferior de la sierra de Umango, antepaís andino (29 S), Argentina: edades U-Pb y caracterizaciones isotópicas. Revista Geológica de Chile 30, 265-284.

Vujovich, G.I., Kay, S.M., 1998. A Laurentian? Grenville-age oceanic arc/back-arc terrane in the Sierra de Pie de Palo, Western Sierras Pampeanas, Argentina. In: Pankhurst, R.J., Rapela, C.W. (Eds.), The Proto-Andean Margin of Gondwana, vol. 142. Geological Society, London, pp. 59-179 (special publication).

Vujovich, G.I., Van Staal, C.R., Davis, W., 2004. Age constraints and the tectonic evolution and provenance of the Pie de Palo Complex. Cuyania composite terrane, and the Famatinian orogeny in the Sierra de Pie de Palo, San Juan, Argentina. Gondwana Research 7, 1041-1056.

Whalen, J.B., Currie, K.L., Chappell, B.W., 1987. A-type granites: geochemical characteristics, discrimination and petrogenesis. Contributions to Mineralogy and Petrology 95, 407-419.

Williams, I.S., 1998. U-Th-Pb Geochronology by ion microprobe. In: McKibben, M.A., Shanks III., W.C., Ridley, W.I. (Eds.), Applications of Microanalytical Techniques to Understanding Mineralizing Processes, Reviews in Economic Geology, vol. 7, pp. 1-35. 